UNIVERSIDADE DE SÃO PAULO

ESCOLA DE ENFERMAGEM

\title{
LUCIA TOBASE
}

A DRAMATIZAÇÃO NO ENSINO DE ENFERMAGEM: UMA REVISÃO SISTEMÁTICA E CRÍTICA DA LITERATURA 


\section{A DRAMATIZAÇÃO NO ENSINO DE ENFERMAGEM: UMA REVISÃO SISTEMÁTICA E CRÍTICA DA LITERATURA}

Dissertação apresentada à Escola de Enfermagem da Universidade de São Paulo para obtenção do título de Mestre em Enfermagem.

Área de concentração:

Administração em Enfermagem

Orientadora:

Profa. Dra. Regina Toshie Takahashi

\section{SÃO PAULO}


Tobase, Lucia.

A dramatização no ensino de Enfermagem: uma revisão sistemática e crítica da literatura. / Lucia Tobase. - São Paulo, 2007.

$92 \mathrm{p}$.

Dissertação (Mestrado) - Escola de Enfermagem da Universidade de São Paulo.

Orientadora: Prof ${ }^{a}$ Dr $^{a}$ Regina Toshie Takahashi.

1. Teatro e educação 2. Psicodrama 3. Estudantes (enfermagem)

4. Pesquisa bibliográfica 5. Métodos de ensino. I. Título. 


\section{DEDICATÓRIA}


Dirigidos ao Alto, profundos agradecimentos ao findar mais um percurso, pronta e fortalecida para novos desafios.

Dedico ao Osvaldo, esposo querido, por representar um esforço conjunto na concretização deste trabalho, por me acompanhar paciente e silenciosamente, por estar sempre presente e disposto a me amparar em todos os momentos de nossa vida.

Ao Thiago, filho querido, amigo e companheiro, que consegue aliar, de maneira admirável, sabedoria e humildade.

Aos meus familiares queridos, pela compreensão, pelo amparo e por partilharem carinhosamente esta jornada.

A todos os alunos, que são professores, e a todos os professores, que também são alunos, porque a arte de ensinar e aprender é permanente e infinita.

“...E quando estiveres perto, arrancar-te-ei os olhos e colocá-los-ei no lugar dos meus;

E arrancarei meus olhos para colocá-los no lugar dos teus; Então ver-te-ei com os teus olhos E tu ver-me-ás com os meus." 
AGRADECIMENTOS 
À Profa. Dra. Regina Toshie Takahashi, pela orientação amiga e paciente.

Ao Prof. Dr. Moacyr Roberto Cuce Nobre, com quem cada palavra trocada foi coroada de saber.

À Profa. Dra. Lídia Ruiz-Moreno, pelo respeito ao ser humano e pelo estímulo frente aos desafios.

À Profa. Dra.Heloisa Helena Ciqueto Peres e à Profa. Dra. Maria de Fátima Prado Fernandes, pelas contribuições no exame de qualificação.

À Emília Emi Kawamoto, pela amizade fraterna, pelo profundo incentivo e valiosa colaboração na revisão textual.

Aos Amigos, preciosos tesouros com quem somos agraciados nesta jornada, pedindo licença para não nomear a cada um, mas profundamente agradecida a todos, pelo carinho, pelo apoio incondicional e presença em todos os momentos desta caminhada.

Ressalto minha gratidão ao CeFACS - Centro de Formação e Aperfeiçoamento em Ciências da Saúde - Instituto do Coração - Fundação Zerbini, por possibilitar a concretização desta etapa e pela contribuição para minha vida profissional .

À Equipe de Colaboradores da Escola de Enfermagem da Universidade de São Paulo, onde cada qual assume seu papel de maneira competente, contribuindo silenciosamente para o progresso da ciência.

"O trabalho escolhido executa-se em colaboração e cada membro do grupo contribui com seus hábitos, seus conhecimentos e coopera na tarefa comum. O fermento de sua colaboração é o prazer de fazer um bom trabalho, de ter colocado sua marca pessoal no resultado coletivo". 
RESUMO / ABSTRACT / RESUMEN 
Tobase L. A dramatização no ensino de Enfermagem: uma revisão sistemática e crítica da literatura [dissertação]. São Paulo: Escola de Enfermagem, Universidade de São Paulo; 2007.

\section{RESUMO}

A reflexão sobre a necessidade de fundamentar as práticas em educação e saúde, promovendo uma ação transformadora, impulsiona o educador na busca de métodos de ensino inovadores. No cenário educacional, acreditamos que a dramatização favorece a aprendizagem do estudante de forma ativa e participativa. Objetivos: Levantar os estudos relacionados com a aplicação da dramatização como estratégia no processo de ensino e aprendizagem na formação profissional em Enfermagem e verificar os resultados da utilização dessa estratégia na aprendizagem do estudante de Enfermagem. Metodologia: Trata-se de uma revisão sistemática da literatura, orientada pela questão norteadora: "Quais os resultados da aplicação da dramatização na aprendizagem do estudante de Enfermagem?". Resultados: Foram encontrados 541 estudos, dos quais 477 foram excluídos e 64 foram incluídos. Dentre os estudos incluídos, todos os $64(100 \%)$ evidenciaram resultados positivos com a utilização da dramatização, 49 (77\%) associaram a relação positiva na aquisição de conhecimento teórico, 42 (66\%) descreveram a melhora na associação entre teoria e prática após a aplicação da estratégia, $29(45 \%)$ relacionaram melhora no pensamento crítico, 19 (30\%) resultaram em melhora do relacionamento interpessoal. Resultados positivos associados à criatividade dos estudantes, ao aspecto comunicacional, à percepção e ao desenvolvimento do senso de coletividade, de trabalho em grupo e comportamento ético profissional também foram comentados. As dificuldades sobre a proposição da atividade dramatizada foram mencionadas em 8 (13\%) estudos, associadas ao embaraço do aluno frente aos colegas pelo medo de exposição no grupo, no relacionamento entre os alunos, dificuldades por parte dos estudantes em estabelecer prioridades. Em $46(72 \%)$ estudos a dramatização foi aplicada no curso de graduação em Enfermagem, respectivamente $8(13 \%)$ e $9(14 \%)$ foram publicados nos anos de 2004 e 2005, sendo que 44 (69\%) eram do tipo descritivo, 40 (63\%) publicados pelos Estados Unidos, 17 (27\%) publicados pela revista Nurse Educator e 12 (19\%) pelo Journal of Nursing Education. Conclusão: Esses achados refletem a relação positiva da dramatização como estratégia facilitadora do processo educativo, pois favorece a aprendizagem, confere significados aos conteúdos, colabora no desenvolvimento de habilidades técnicas e comunicacionais, na percepção do ser humano de maneira holística, estimulando a criatividade, o pensamento crítico e o relacionamento interpessoal, além de proporcionar um ambiente tranqüilo e seguro para o processo ensino aprendizagem. Favorecendo a construção das competências, a dramatização contribui para a formação do futuro profissional em Enfermagem.

Descritores: Educação em Enfermagem. Estudantes de Enfermagem. Dramatização. Psicodrama. Simulação. 
Tobase L. The role playing in nursing education: systematic and critical literature review. (A dramatização no ensino de Enfermagem: uma revisão sistemática e crítica da literatura) [dissertation]. São Paulo: "Escola de Enfermagem, Universidade de São Paulo", 2007.

\section{ABSTRACT}

The consideration about the need to support education and health practices, promoting transforming actions, drives the educator in search for innovative teaching methods and, within educational context, we think that role playing favors students' learning in an active and participative fashion. Objectives: To identify studies related with the use of the role playing as a strategy in the process of teaching/learning in professional nursing training and to check the results of using such strategy in the learning of nursing students. Methodology: This study was a systematic literature review guided by the key question: "What are the results of the use of the role playing in the learning of nursing student?". Result: There were 541 identified studies, out of which 477 were excluded and 64 were included in the analysis. Among the included studies, all $64(100 \%)$ showed positive results with the use of role playing, 49 $(77 \%)$ associated positive correlation with acquisition of theoretical knowledge, 42 (66\%) described improvement in the association between theory and practice using the strategy, and $29(45 \%)$ related improvement of critical thinking, $19(30 \%)$ resulted in improvement of interpersonal relationship. Positive results associated with undergraduate creativity, communication skills, perception and development of a sense of collectiveness, team work and professional ethical attitudes were also mentioned. Difficulties in the use of role playing activity were mentioned in 8 $(13 \%)$ studies, associated with students' embarrassment before classmates because of fear of public exposure, relationship with them and difficulties that students had to define priorities. In 46 studies (72\%), the role playing was applied to undergraduate nursing course, respectively, $8(13 \%)$ and $9(14 \%)$ studies were published in 2004 and 2005, and 44 (69\%) were descriptive, 40 $(63 \%)$ were published in the United States, $17(27 \%)$ were published by Nurse Educator Journal, and $12(19 \%)$ by Journal of Nursing Education. Conclusion: These findings show a positive contribution of the role playing as a facilitating strategy in the educational process. It favors learning, conveys meaning to contents, collaborates in the development of technical and communication skills, enhances the perception of human beings within a holistic fashion, stimulating creativity, critical thinking and interpersonal relationship. In addition, it provides a calm and safe environment for teaching and learning; by favoring the building of competences, role playing contributes in the nursing education.

Key words: Nursing Education. Nursing students. Role playing. Psychodrama. Simulation. 
Tobase L. La dramatización en la enseñanza de Enfemería: una revisión sistemática y critica de la literatura [disertación]. São Paulo: "Escola de Enfermagem, Universidade de São Paulo"; 2007.

\section{RESUMEN}

La reflexión sobre la necesidad de fundamentar las prácticas en educación y salud, promoviendo una acción transformadora impulsiona al educador por la búsqueda de métodos de enseñanza innovadores. En el escenario educacional se cree que la dramatización favorece el aprendizaje del estudiante en forma activa y participativa. Objetivos: Levantar los estudios relacionados a la aplicación de la dramatización como estrategia en el proceso de enseñanza-aprendizaje durante la formación profesional en Enfermería y, verificar los resultados de la utilización de esta estratégia en el aprendizaje del estudiante de Enfermería. Metodología: Se trata de una revisión sistemática de literatura realizada en el período de Enero a Septiembre del 2006, orientada bajo la siguiente pregunta ¿Cuáles son los resultados de la aplicación de la dramatización en el aprendizaje del estudiante de Enfermería?. Resultados: Fueron encontrados 541 estudios, de los cuales 477 fueron excluidos e 64 fueron incluidos. Dentro de los estúdios incluidos, todos los estudios 64 (100\%) evidenciaron resultados positivos con la utilización de la dramatización, siendo que, 49 (77\%) presentaron una relación positiva en la adquisición del conocimiento en el aspecto teórico, $42(66 \%)$ describieron la mejora en la asociación entre la teoria y la práctica después de la aplicación de la estratégia, 29 (45\%) relacionaron mejora en el pensamiento crítico, $19(30 \%)$ resultaron en mejora del relacionamiento interpersonal. También fueron encontrados resultados positivos relacionados a: la creatividad de los estudiantes en el aspecto de la comunicación, percepción, desenvolvimiento de sentido de colectividad, de trabajo en grupo y del comportamiento ético profesional. Las dificultades sobre la proposición de la actividad dramatizada fueron mencionados em $8(13 \%)$ estúdios, los cuales estaban asociados a la verguenza del alumno frente a sus compañeros, cuando éste es expuesto en el grupo, relacionamento entre los alumnos, dificultades por parte de los estudiantes en establecer prioridades. En 46 (72\%) de los estudios, la dramatización fue aplicada en el curso de graduación en Enfermería, respectivamente $8(13 \%)$ y $9(14 \%)$ fueron publicados en los años de 2004 y 2005; siendo que, 44 (69\%) eran del tipo descriptivo. Los Estados Unidos fue el país responsable por la mayoría de las publicaciones encontradas correspondiendo a $40(63 \%)$ artículos, de los cuales $17(27 \%)$ fueron publicados por la revista Nurse Educator y 12 (19\%) vinculados por el Journal of Nursing Education. Conclusión: Estos resultados reflejan la relación positiva de la dramatización como estratégia facilitadora en el proceso educativo, el cual favorece el aprendizaje, atribuye significados a los contenidos, colabora en el desenvolvimiento de habilidades técnicas y de comunicación en la percepción del ser humano de forma global. Así como también estimula la creatividad, el pensamiento crítico y el relacionamiento interpersonal, además de proporcionar un ambiente tranquilo y seguro en el proceso de enseñanza-aprendizaje. De esta forma se favorece la construcción de competencias lo que contribuye en la formación del futuro profesional de Enfermería.

Descriptores: Educación em Enfermería. Estudiantes de Enfemería. Desempeño de Papel. Psicodrama. Simulación. 
LISTAS 


\section{LISTA DE QUADROS}

Quadro 1 - Estrutura do Psicodrama segundo os instrumentos, contextos e etapas do processo, São Paulo - 2007.

Quadro 2 - Estrutura do Psicodrama Pedagógico segundo a integração de valores e habilidades, São Paulo - 2007 ........18

Quadro 3 - Quadro comparativo entre o Psicodrama Pedagógico e a Pedagogia do Drama, São Paulo - 2007

Quadro 4 - Lista dos estudos incluídos, São Paulo - 2007 ......................44

\section{LISTA DE TABELAS}

Tabela 1 - Distribuição dos estudos encontrados segundo o ano de publicação, São Paulo - 2007.

Tabela 2 - Distribuição dos estudos encontrados segundo a fonte de publicação dos estudos, São Paulo - 2007

Tabela 3 - Distribuição dos estudos encontrados segundo a área de aplicação da dramatização, São Paulo - 2007

Tabela 4 - Distribuição dos estudos encontrados segundo a categorização dos resultados, São Paulo - 2007

Tabela 5 - Distribuição dos estudos encontrados segundo as dificuldades para aplicação da dramatização, São Paulo 2007

\section{LISTA DE FIGURAS}

Figura 1 - Distribuição dos estudos encontrados segundo o país de origem, São Paulo - 2007

Figura 2 - Distribuição dos estudos encontrados segundo o nível de formação profissional da população estudada, São Paulo 2007

Figura 3 - Distribuição dos estudos encontrados segundo o desenho metodológico, São Paulo - 2007 


\section{SUMÁRIO}

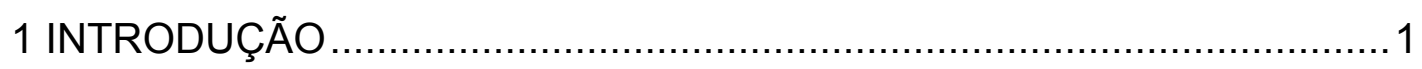

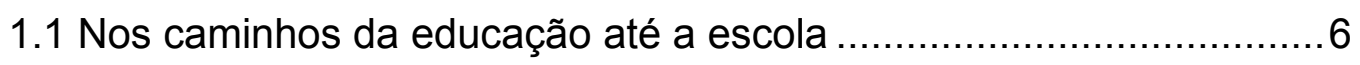

1.2 A história dos caminhos do teatro escolar e da dramatização..........13

1.3 A dramatização no processo educativo .........................................16

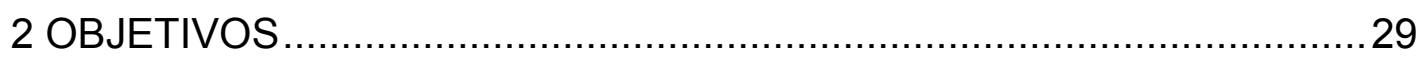

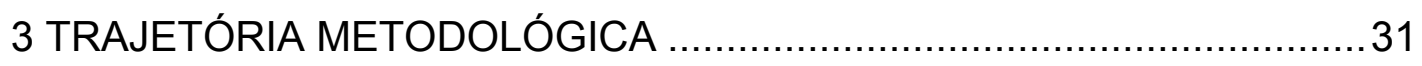

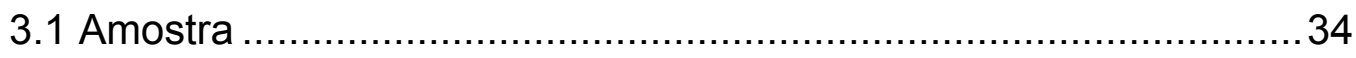

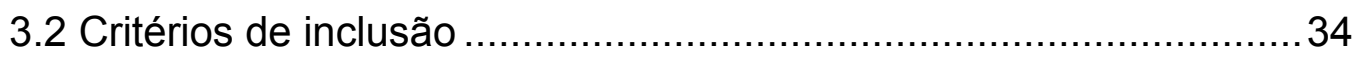

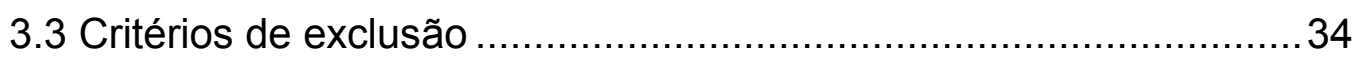

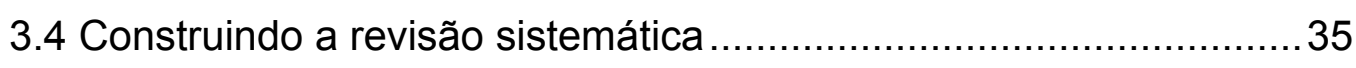

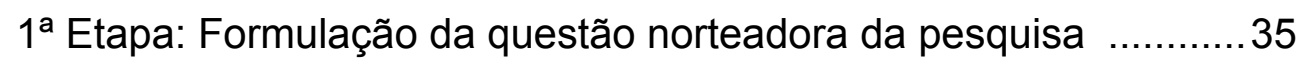

$2^{a}$ Etapa: A revisão nas bases de dados ........................................ 38

$3^{\text {a }}$ Etapa: Identificação dos estudos a serem incluídos na revisão... 40

$4^{a}$ Etapa: Seleção e avaliação dos estudos encontrados .................41

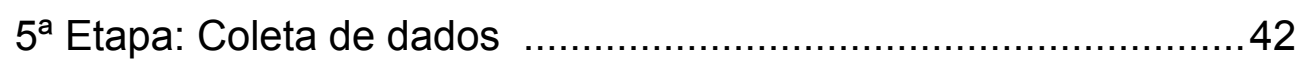

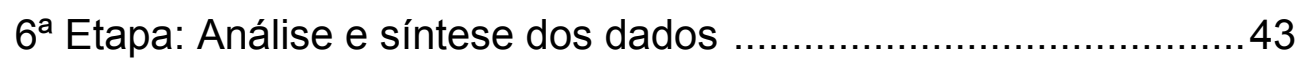

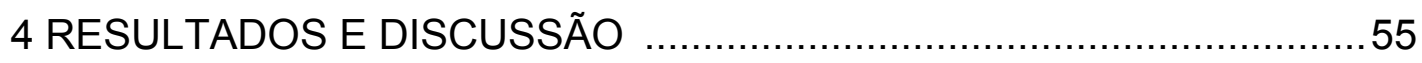

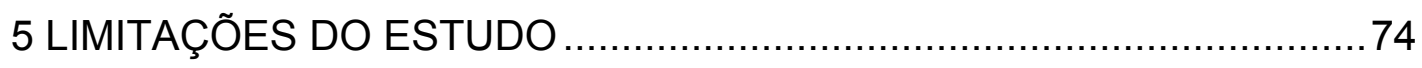

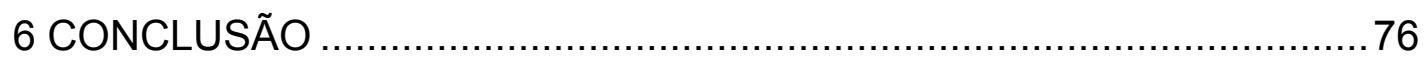

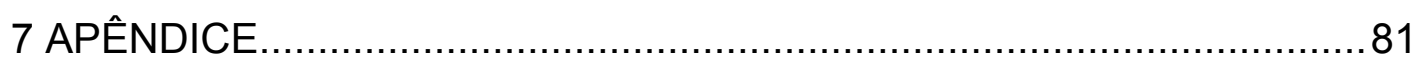

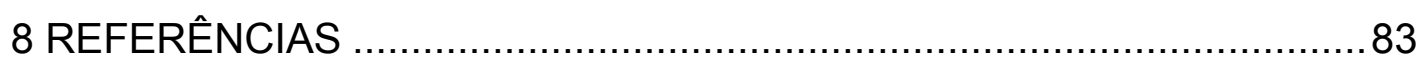


1 INTRODUÇÃO 


\section{INTRODUÇÃO}

A educação é um fenômeno humano cujas manifestações originam um patrimônio de reconhecida grandeza, ao Homem e à sociedade. Vinculada a um conjunto de valores que se modificam ao longo dos tempos, acompanha os caminhos naturais dessa evolução. Proporciona uma riqueza de conhecimentos e informações de suma importância para a melhor compreensão das variadas linhas das ciências associadas aos modos de produção do conhecimento, às diferentes concepções relacionadas com a apropriação do saber e com as correntes de pensamento que tentam explicar o processo de aprendizagem do ser humano.

A produção do conhecimento está associada não só ao ambiente escolar, mas a tudo o que nos cerca, seja como um acontecimento marcante, um fato histórico, de natureza social, política ou econômica, pois, nas adjacências do acontecimento, desvelamos outros aspectos que nos permitem compreender os mecanismos que regem determinado contexto, a intencionalidade das ações e suas conseqüências.

A compreensão dos modos como o conhecimento é produzido contribui para levar a uma reflexão sobre a práxis, cuja análise promove a ação de forma a permitir uma intervenção adequada na trajetória da realidade, no ensino e na formação profissional.

A reflexão sobre a prática pedagógica deve ser uma constante no cotidiano do educador: "Por que ensinar?", "Para quê?", "Para quem?", "Quais os resultados?".

Essas questões simples em seu formato, porém grandiosas em sua essência, proporcionam elementos valiosos que irão subsidiar essa prática, conferindo sentido ao desenvolvimento do trabalho do educador e do educando, associado à definição dos objetivos em relação à formação escolar do corpo discente, às metodologias de ensino e de avaliação. Numa permanente condição reflexiva, o docente avalia e reavalia sua práxis compreendendo a influência de diversos fatores nesse processo, 
reconhecendo a necessidade de fundamentar as práticas em educação e saúde, promovendo uma ação transformadora. Essa reflexão impulsiona a busca por métodos de ensino includentes, de maneira a assegurar que o estudante seja autor na construção do seu conhecimento no processo educativo.

Nesse sentido, a instituição que participa da formação do profissional em Enfermagem deve buscar um eixo de ensino em que o aluno não seja um mero receptor de informações, mas como sujeito do processo de ensino e aprendizagem, tenha uma participação ativa através de experimentações e seja colocado próximo à realidade ${ }^{(1)}$. Assim, o futuro profissional exercitará uma postura crítica, desafiadora, observando e buscando soluções, repudiando a zona de conforto da passividade e do conformismo.

Esse exercício é favorecido quando a construção do conhecimento ocorre de forma ativa. A utilização de métodos de ensino inovadores e problematizadores - como estudos de caso, jogos, debates, dramatizações e simulações de situações semelhantes à realidade que o sujeito encontrará no cotidiano de seu trabalho - facilita a compreensão mediante a aprendizagem contextualizada ${ }^{(2)}$.

Em nossa prática escolar, como docentes da área de saúde e atuantes na formação profissional em Enfermagem, verificamos que essas estratégias possibilitam a mobilização do conhecimento e a articulação de diversos aspectos necessários à aprendizagem e que estão relacionados com o desenvolvimento de habilidades, conhecimento e associação de informações provenientes de outros componentes curriculares através da interdisciplinaridade e da transversalidade. Também contribuem para o desenvolvimento do senso crítico e do comportamento ético, promovendo o exercício de cidadania, colaborando na construção das competências do futuro profissional.

Por se tratar do alvo deste estudo, remetemos nossa abordagem ao ambiente escolar, ou seja, à escola e à formação profissional em 
Enfermagem, concentrando-nos na dramatização como alternativa metodológica no processo de ensino e aprendizagem.

O nome dramatização deriva da palavra drama, cuja tradução do grego significa ação, realização. A finalidade do teatro na escola está relacionada com o aprender a pensar, aprender a expressar o pensamento, aprender a entender o pensamento alheio. A dramatização é a ação realizada pelo(s) sujeito(s) durante a interpretação; é o momento em que o estudante abandona seu papel de aluno e assume o papel do personagem proposto em uma estória. No cenário preparado, os personagens entram em cena comentando, refletindo, expressando a mensagem e manifestando, durante a apresentação, a espontaneidade, a criatividade e o resultado da elaboração das idéias.

Em busca de veículos para uma educação transformadora, acreditamos ser a dramatização uma estratégia que confere significados aos conteúdos. Tomamos como referência a nossa vivência em um Curso de Enfermagem em que os alunos manifestaram satisfação em participar das atividades e mostraram-se muito comprometidos, explicitando que o estudo e a apreensão dos conteúdos favoreceram seu amadurecimento e os tornaram mais críticos e criativos.

De forma especial, despertamos nossa atenção para o papel do educador e do educando. Com base em nossa experiência na docência, bem como nos estudos encontrados na literatura sobre a referida estratégia, reconhecemos que a formação profissional de forma contextualizada, crítica, reflexiva e transformadora é determinante para o futuro profissional, desenvolvendo concepções de cunho coletivo, responsável e participativo.

Consideramos, então, que a dramatização pode ser empregada como um veículo facilitador do processo educativo em Enfermagem, mediante uma ação conjunta na qual os estudantes constroem o saber de forma ativa e participativa. A dramatização favorece a aprendizagem, cujo resultado final revela o sentido dos momentos anteriores, ao fortalecer os conhecimentos adquiridos por meio de representações e de experiências concretas, ao 
contrário das exposições verbais que levam o aluno ao exercício da abstração, o que dificulta o aprendizado.

$\mathrm{Na}$ busca de mais conhecimentos sobre a dramatização como estratégia facilitadora e diante das inúmeras possibilidades de sua aplicação no processo de ensino e aprendizagem, despertou-nos o interesse em verificar, por meio da revisão sistemática dos estudos realizados, as evidências sobre a utilização dessa estratégia como método educacional em Enfermagem.

Então, previamente ao início desta pesquisa, efetuou-se um levantamento de informações, nas diversas bases de dados eletrônicas existentes, a respeito de alguma revisão semelhante ao presente estudo.

Não se encontrou nenhuma revisão sistemática sobre o tema, o que nos levou a iniciar esta investigação, norteada pela seguinte questão: “Quais os resultados da aplicação da dramatização na aprendizagem do estudante de Enfermagem?"

Com o intuito de colaborar para a compreensão do tema e apoiada em referenciais teóricos sobre a relação entre o universo educacional e o teatro no ambiente escolar, apresentamos, nos itens que se seguem, as descrições e considerações acerca das bases conceituais da educação, da trajetória histórica do teatro, desvendando suas origens e a relação pedagógica solidária como ambiente favorável ao processo educativo, culminando com a inserção da dramatização enquanto estratégia facilitadora na formação profissional em Enfermagem.

"Gostarei de aprender com ele porque acredito que ele nunca aprenderá aquilo que não aprendamos juntos. Assim, ambos nos proporemos a aprender". Rousseau 


\subsection{NOS CAMINHOS DA EDUCAÇÃO ATÉ A ESCOLA}

Ferreira ${ }^{(3)}$ conceitua a educação como "ato ou efeito de educar (-se). Processo de desenvolvimento da capacidade física, intelectual e moral do ser humano, visando à sua melhor integração individual e social".

Na concepção de Libâneo ${ }^{(4)}$

...a educação, em um sentido amplo, compreende os processos formativos que ocorrem no meio social, no qual os indivíduos estão envolvidos, de modo necessário e inevitável, pelo simples fato de existirem socialmente.

Em um sentido mais restrito, relata que

...esses processos formativos ocorrem em instituições específicas, escolares ou não, com finalidades explícitas de instrução e ensino, mediante uma ação consciente e intencional, deliberada e planificada, embora sem separar-se daqueles processos formativos gerais.

Reconhecendo a necessidade de compreensão dos interesses sociais, políticos, econômicos, culturais presentes na prática educativa, esse autor revela as imensas fronteiras que delimitam a educação, enfatizando que as relações sociais existentes na sociedade são mutáveis e dinâmicas por serem constituídas pela ação humana na vida social e, portanto, podem ser transformadas.

A abrangência da educação é reconhecida na Lei de Diretrizes e Bases da Educação Nacional (LDB), aprovada pela Lei n. 9.394, $1996{ }^{(5)}$, e o Artigo 1 define seu objeto específico:

A educação abrange os processos formativos que se desenvolvem na vida familiar, na convivência humana, no trabalho, nas instituições de ensino e pesquisa, nos movimentos sociais, nas organizações da sociedade civil e nas manifestações culturais.

Os parágrafos $1^{\circ}$ e $2^{\circ}$ explicitam que a educação escolar desenvolver-se-á, predominantemente, por meio de ensino em instituições próprias, vinculada ao mundo do trabalho e à prática social. Dentre as várias redes existentes ligadas ao saber, a escola é considerada a principal representante. Posicionada como o eixo central, ainda que não exclusivo, da educação nas sociedades modernas, uma vez que o processo de educação inicia-se em 
casa, está presente no trabalho e é amplamente favorecido pelos meios de comunicação $^{(6)}$.

Obry ${ }^{(7)}$ nos conta que a palavra escola deriva do grego scholé, cujo significado está associado ao lazer, recreação, repouso. Em virtude da evolução natural do passado até o presente, esse significado original já não acompanha o atualmente atribuído à escola, cujo papel vai muito além de proporcionar lazer. Traz consigo a importância relativa à formação do ser humano, quanto ao aspecto intelectual, profissional e de cidadania. A escola representa o espaço formador que agrega uma comunidade com objetivos definidos; adota, em suas ações pedagógicas, uma postura que revela a visão da realidade e reflete a posição de aceitação dessa realidade ou a necessidade de sua transformação, imprimindo a sua marca social.

Destarte, a escola deixou de ser concebida apenas como uma agência de instrução. Além de proporcionar a educação formal que visa prover os fundamentos básicos do aprendizado conferindo significado às informações, estimula a capacidade de reflexão crítica, reconhecendo a condição do indivíduo como cidadão.

Assim como a educação, a área da saúde está inserida no setor de serviços e integra o conjunto das atividades denominadas serviços de consumo coletivo.

A saúde ${ }^{(8)}$ é produto de um amplo espectro de fatores relacionados com a qualidade de vida e com a compreensão de que promover saúde resulta de um conjunto articulado de atividades, processos e recursos de origem governamental, institucional e comunitária. Trata-se de um setor que necessita de profissionais capacitados tanto para a inserção quanto para a atuação nesse conjunto articulado de atividades.

Tobase ${ }^{\left({ }^{*}\right)}$ nos lembra que, em decorrência da constante introdução de inovações tecnológicas, bem como da busca pela melhoria da qualidade e

\footnotetext{
* Tobase L. A análise do projeto político pedagógico de uma escola segundo o referencial teórico transformador e emancipador. [monografia]. São Paulo: Escola de Enfermagem, Universidade de São Paulo; 2004.
} 
produtividade dos serviços, torna-se imperativa a compreensão global do processo de trabalho para o desenvolvimento de modelos de atenção voltados para a qualidade de vida e a integração das ações dos diferentes agentes que atuam na área da saúde.

Kawamoto (9) relata que estudos sobre os impactos das novas tecnologias revelaram a exigência de profissionais mais polivalentes, capazes de interagir em situações novas e em constante mudança. Dentro desse contexto, as instituições responsáveis pela formação profissional buscam diversificar os conteúdos programáticos, adotam diferentes metodologias de ensino e procuram melhorar a qualidade do ensino, pois o aumento dos níveis de exigência do mercado de trabalho determina alterações na estrutura rígida de ocupações e requer trabalhadores mais qualificados.

Nesse contexto, a área de Enfermagem é caracterizada pelas peculiaridades de suas atribuições quanto à prestação de assistência nos diferentes níveis de atenção à saúde. As ações dos profissionais dessa área são extensas. Atuam na prevenção, realizada por meio de trabalhos educativos, proporcionando orientações e ações preventivas, passam pelo diagnóstico precoce e tratamento de disfunções, com a prestação de cuidados diretos, e culminam na recuperação e reabilitação do indivíduo, considerando-o como um cidadão que tem um papel e uma importância social.

A magnitude dessas ações nos remete à reflexão sobre o ensino profissional em Enfermagem e a competência dos futuros profissionais. Perrenoud ${ }^{(10)}$ entende que são múltiplos os significados da noção de competência profissional e a define como a "capacidade de agir eficazmente em um determinado tipo de situação, apoiada em conhecimentos, sem limitar-se a eles". Para enfrentar essa diversidade de situações da melhor maneira possível, o estudante deve mobilizar, no cenário educacional, vários recursos além dos cognitivos. O desenvolvimento dessa capacidade é favorecido em grande parte na escola, pela articulação do conhecimento, 
com mecanismos relacionados à análise, à realização do trabalho do profissional e sua vivência como cidadão.

Desse modo, é fundamental manter o foco nesses conceitos ao se traçarem os objetivos da formação do futuro profissional em Enfermagem. Entendemos que a entidade formadora, ao desenhar o perfil do futuro profissional, deve considerar todos os aspectos que proporcionam a formação integral do indivíduo, colaborando na construção das competências desse sujeito.

Contribuem para isso a tendência e o modelo pedagógico adotados na instituição, onde se pode observar a existência de diversas tendências pedagógicas conforme o momento histórico e o contexto em que está inserida. Tomando emprestadas as indicações de Libâneo ${ }^{(4)}$ e Luckesi ${ }^{(11)}$ acerca das tendências pedagógicas que servem de matriz para a escola brasileira, dentre tantas existentes - como a tradicional, liberal, tecnicista, não-diretiva, crítica, crítico-social dos conteúdos, pós-críticas - no universo educacional, ainda predominam as tendências tradicionais.

Durante longo período, as ações educativas tiveram como referência o método de ensino tradicional. Suas diretrizes delineadas pelas concepções conservadoras, relacionavam-se com o modelo de controle, buscando manter esse controle e o condicionamento sobre os alunos, conduzindo-os para objetivos que não escolheram e sobre os quais tinham pouca ou nenhuma influência, bem como não desenvolviam a sua capacidade de reflexão e de inserção na sociedade.

Freire ${ }^{(12)}$ refere-se a esse tipo de ensino como "Educação Bancária", aonde o professor é considerado detentor e transmissor do conhecimento depositado verbalmente para o aluno, cujos conhecimentos e experiências próprias de vida não são considerados em relação ao conteúdo que "precisa aprender", imperando o autoritarismo nos níveis gestores, administrativos e na relação educador - educando. Ao adotar rigorosamente esse modelo de ensino, a escola formadora do futuro profissional em Enfermagem corre o 
risco de não lhe propiciar a busca e a construção do conhecimento, de não estimular a capacidade de análise, do pensamento crítico e sua criatividade.

“....respeita o jeito próprio do indivíduo pensar. Não se obriga a acompanhar necessariamente o estilo de pensar do professor. .. deixa o aluno caminhar com seus próprios passos e não apenas acompanhar os passos do professor..." Pestalozzi

Gradativamente, as concepções conservadoras foram perdendo espaço, evidenciando que o modelo de "Educação Bancária" que caracterizava o ensino tradicional tornava-se ultrapassado. Assim, não só o conhecimento científico assume importância, mas, também a realidade social do aluno, da escola e da comunidade, expressando um compromisso com a sociedade, deslocando a discussão dos conceitos pedagógicos e psicológicos e das técnicas de ensino para a questão do poder e da ideologia na educação. O autoritarismo cede lugar à democratização da educação escolar e a prática pedagógica volta-se para o homem em sua omnilateralidade, comprometida com o indivíduo como um todo.

Nesse contexto, as novas tendências pedagógicas críticas incitam à análise e reflexão sobre o modelo de ensino tradicional, conferem outro enfoque à educação, agora voltada para o desenvolvimento de uma consciência crítica e emancipadora, evidenciando uma atitude libertária, traduzindo-se em ações conscientes de reivindicação em lugar de uma aceitação passiva e de uma atitude fatalista frente à realidade ${ }^{(13)}$.

Nesse sentido, a responsabilidade da instituição formadora é destacada por Tobase e Takahashi ${ }^{(14)}$. As autoras ressaltam que a escola deve estar atenta a fim de se instrumentalizar de forma coerente, desenvolvendo ações que permitam uma intervenção adequada na trajetória educativa. Um dos fatores que determina se a escola e a formação por ela proporcionada são conservadoras ou progressistas não é apenas o tipo de saber veiculado, mas a maneira como é veiculado através do método didático adotado pelo professor. 
Luckesi (15) comenta que a aprendizagem ativa, construída pelo educando a partir da assimilação dos conteúdos socioculturais, ocorre na medida em que for inteligível, conferindo significados ao conhecimento que desvela a realidade. Dessa maneira, conteúdos programáticos de cunho essencialmente teórico podem ser abordados e compreendidos ao se utilizarem estratégias de ensino problematizadoras, pois, ao mesmo tempo em que podem ser desafiadoras, representam uma face amena da realidade que o aluno enfrentará na vida profissional. Com freqüência, esses movimentos resultam em um aumento da percepção do senso de responsabilidade, do estudante precisando fazer algumas escolhas que visam ao interesse coletivo e não apenas ao interesse pessoal. Ao assumir a sua parcela de responsabilidade, o aluno já não a transfere integralmente ao professor, o que estimula o senso de maturidade nas decisões frente à coletividade.

A nossa experiência profissional na área do ensino em Enfermagem, a necessidade de transformar a aprendizagem passiva em aprendizagem ativa, a inquietação frente à necessidade de aperfeiçoar o aprendizado sem menosprezar a vivência dos alunos, os diversos experimentos pedagógicos desenvolvidos na docência, estimularam-nos a ampliar os conhecimentos sobre os métodos de ensino inovadores.

Observamos que muitos docentes atuantes no ensino profissional em Enfermagem avaliam a sua práxis, tentam compreender a influência de diversos fatores nesse processo, respeitam as diversidades e reconhecem a necessidade de fundamentar as práticas em educação e saúde, buscando promover a sua transformação.

A nossa prática escolar permite-nos afirmar que, quando essas estratégias são desenvolvidas na dinâmica curricular pelos docentes, considerando a interdisciplinaridade e a transversalidade, os alunos demonstram maior capacidade em mobilizar e articular os saberes, o que facilita a aprendizagem e o desenvolvimento da competência profissional almejada pelas instituições de ensino e de trabalho. 
A busca de estratégias como veículo desse processo levou-nos a considerar a dramatização como sendo aquela que confere significados aos conteúdos. Tal afirmação baseia-se em nossa experiência no ensino em Enfermagem, onde os alunos manifestaram satisfação em participar das atividades, mostraram-se muito comprometidos com o processo ensinoaprendizagem, o que favoreceu o estudo e a apreensão dos conteúdos além de estimular o desenvolvimento do senso crítico e da criatividade. Acreditamos que, dessa forma, retomamos o sentido histórico da palavra escola que, na concepção grega, estava associada ao lazer, recreação e repouso; a dramatização pode ser um meio prazeroso pelo qual o aluno aprende e transmite os seus saberes ao grupo. O desenvolvimento dessa habilidade comunicacional será valiosa na vida profissional dos alunos, pois uma das atividades de enfermagem está relacionada com a educação em saúde.

Além da melhora do conhecimento, estudos diversos confirmam nossas considerações ao descreverem que a dramatização possibilita o desenvolvimento de habilidades ${ }^{(16,17,18,19)}$, contribui para a melhora do relacionamento ${ }^{(20,21)}$, da percepção do outro e das suas formas de comunicar-se ${ }^{(22,23)}$, para o desenvolvimento do senso crítico ${ }^{(24)}$ e do trabalho em grupo $(25,26)$.

Moreno (27) corrobora essas percepções quando refere que "dramatizações são propostas de trabalhos que tratam conteúdos curriculares e que compreendem: aprender na ação, uma metodologia de ensino democrática e participativa".

“... aprender é, também, poder mudar, agregar, consolidar, romper, manter conceitos e comportamentos, que vão sendo reconstruidos nas interações sociais. São nesses movimentos de transformação que as pessoas vão elaborando suas possibilidades de intervir no mundo, questionando o estabelecido, concordando ou não com as opções coletivas e contribuindo com alternativas de superação". Batista 


\subsection{A HISTÓRIA DOS CAMINHOS DO TEATRO ESCOLAR E DA DRAMATIZAÇÃO}

A Arte tem sido concebida como um instrumento fundamental da educação, ocupando historicamente papéis diversos, desde Platão, que a considerava como a base de toda a educação natural, até a proposta contida nos Parâmetros Curriculares Nacionais ${ }^{(28)}$. A aproximação entre as ciências e as artes é um fenômeno apreciável da época atual. A tarefa, em ambos os campos, esteve, até muito pouco tempo, afastada de um critério unificador que proporcionasse aos seres humanos a possibilidade de uma melhor compreensão de sua problemática particular e geral.

Gasset ${ }^{(29)}$ estabelece a desejada aproximação entre a educação e a arte através do teatro. Associa o trabalho com a imaginação buscando um entendimento do mundo por meio do resgate de textos que auxiliam na compreensão do comportamento social, além de contribuírem para a construção do conhecimento como objetivo educacional.

O teatro foi formalizado pelos gregos como demonstração de cultura e de conhecimento ${ }^{(30)}$. Na Grécia Antiga, vigorava a crença na existência de inúmeros deuses e em um país chamado Hélade, os homens acreditavam em Dionísio, o alegre deus da fertilidade, da figueira e do vinho. Em sua honra, faziam festas com grandes cortejos animados, constituídos pelos adoradores do deus e dirigidos por um corifeu. Esse coro alegre recitava diritambos - poemas longos e dialogados - cujas histórias quase sempre versavam sobre um lendário herói grego marcado pela fatalidade. Com o passar do tempo, a fim de tornar a história mais viva e real, eles passaram a fingir, por meio de representações, serem esses heróis do poema. $E$ mais tarde, quando o poeta Ésquilo escreveu diritambos com mais de um personagem, demarcou o surgimento da tragédia grega, precursora do teatro no mundo ocidental.

Percebemos nesse percurso histórico que o teatro grego é muito diferente do atual, mas as tragédias e comédias gregas continuam 
contribuindo para a formação cultural de um povo, por atuarem tanto na individualidade como na manifestação que nasce de um coletivo - a sociedade onde se insere. Seus traços permanecem não só nas mentes, mas também nas falas dos espectadores, levando-os à discussão, à reflexão e à análise da mensagem. O teatro é, portanto, veículo de civilização, de cultura, de comportamento dialético, de educação.

Courtney ${ }^{(31)}$ menciona algumas passagens relacionadas com a evolução do processo dramático na educação, associando-a às concepções de figuras históricas:

“... Platão, por volta do século V a.C., considerava que a educação devia começar cedo, de maneira lúdica e sem qualquer ar de constrangimento". Porém, acreditava que o teatro era uma imitação da realidade, o que limitaria a manifestação daquele que aprendia.

“... Aristóteles entendia que a educação devia preparar o aluno para a vida prática e ao mesmo tempo proporcionar lazer". E, nesse contexto, discordava de Platão, pois acreditava que o teatro não imitava a realidade, mas as idéias abstratas dela provenientes, o que acentuava ou amenizava os fatos da vida real.

“... Carlos Magno, imperador romano por volta do ano 800, fundou escolas e monastérios por toda a Europa; reapareceram os trabalhos de Aristóteles e o cenário estava pronto para a reavaliação do teatro". Nessa base, o teatro cristão pôde se desenvolver através da criação do teatro litúrgico com um propósito didático centrado nas escolas monásticas. Escolas e livros eram privilégios de poucos; foi o teatro quem propiciou educação à grande massa da população.

“... Inácio de Loyola fundou em 1534 a ordem jesuítica no Brasil; a ênfase didática pode ser observada, na maioria das peças, escritas pelos professores ou pelos alunos".

“... Rousseau, em 1762, abriu as portas a Montessori, Pestalozzi, Dewey e Caldwell Cook ao considerar que a educação deveria ser livre, prazerosa, através do encorajamento, sem castigos ou reprimendas, 
reivindicando a importância dos sentimentos como base das normas de conduta moral, opondo-se abertamente ao racionalismo da época." O uso de jogos e formas de expressão era adotado como estímulo das potencialidades individuais do aluno.

“... Caldwell Cook, em 1917, elaborou a primeira formulação do método dramático na obra The Play Way. Acreditando que atuar era um caminho seguro para aprender, seu método estava fundamentado em três princípios básicos: 1) proficiência e aprendizado não advêm da disposição de ler ou escutar, mas da ação, do fazer e da experiência; 2) o bom trabalho é mais frequentemente, resultado do esforço espontâneo e livre de interesse do que da compulsão e aplicação forçada; 3) o meio natural de estudo, para a juventude, é o jogo. A partir de então, o método Play Way de ensino para todas as disciplinas do currículo ganhou vulto. As várias edições dos Handbooks for Teachers (Ministry of Education) sugeriam o método dramático para o ensino da linguagem, história, literatura, arte e outras disciplinas.

Remetendo o método dramático ao campo psicoterapêutico, Moreno $^{(32)}$ realizou, em 1911, seus primeiros experimentos de teatro espontâneo, que alguns anos mais tarde levariam à descoberta e depois, à elaboração de uma nova técnica de expressão, o Psicodrama. Terapeuticamente diferente de Freud, o paciente que deveria estar só, no divã, é colocado por Moreno juntamente com outros, no teatro. Representa o ponto decisivo na passagem do tratamento do indivíduo isolado para o tratamento do indivíduo em grupos; do tratamento do indivíduo com métodos verbais para o tratamento com métodos de ação. O autor denominou Psicodrama o método em que o analista está preocupado com um indivíduo atuando com outros, diferenciando-se do Sociodrama, quando o analista está preocupado com o grupo todo, envolvido em uma situação dramática. $O$ referido autor enfatiza a riqueza de recursos técnicos de que dispõe o Psicodrama, conferindo-lhe uma grande ductibilidade e possibilidades de aplicação em outros campos. 
Das diversas técnicas do Psicodrama, o role playing (jogo de papéis) surge como a mais utilizada em diversos campos. Ela se aplica ao ensino, no nível fundamental ou universitário, com as devidas adaptações ao programa a ser abordado. Aplica-se também à preparação de candidatos às mais diversas especialidades e, como coadjuvante, em áreas terapêuticas que visam a reduzir tensões em problemas conjugais, familiares e grupais.

No Brasil, a mais antiga notícia que se tem da aplicação do Psicodrama, segundo Florez ${ }^{(33)}$, data de 1930, introduzido por Helena Antipoff em Belo Horizonte, Minas Gerais.

Ainda que a dramatização seja considerada oriunda do campo do Psicodrama, o alvo deste estudo não será a abordagem psicológica mas sim, a relação do uso da dramatização como estratégia facilitadora no processo educativo e na aprendizagem do estudante, na formação profissional em Enfermagem.

"O mundo inteiro é um palco e todas as mulheres e homens são apenas atores. Se encontram e vão se embora. Durante toda a vida, encenam papéis... "Shakespeare

\subsection{A DRAMATIZAÇÃO NO PROCESSO EDUCATIVO}

Em linhas gerais, encontramos nos relatos de Romana ${ }^{(34)}$ que, no Brasil e Argentina, até os anos 60, predominava a mentalidade de que Psicodrama era sinônimo de psicoterapia, não se especulando se poderia ser aplicado em outros campos. 
Quadro 1 - Estrutura do Psicodrama, segundo os instrumentos, contextos e etapas do processo, São Paulo - 2007.

\section{Prática Psicodramática}
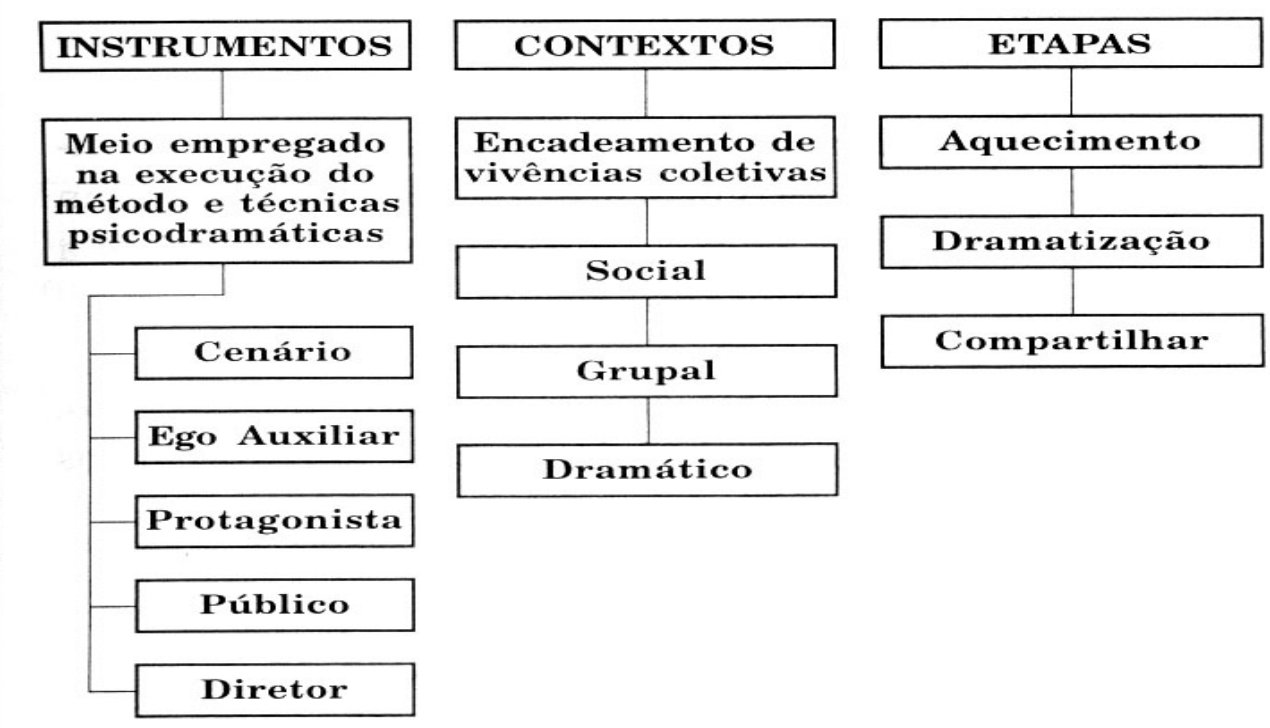

Fonte: Psicodrama em sala de aula. Taís Lima. São Paulo: Vetor; 1998.

O quadro 1 apresenta os elementos do Psicodrama relacionando seus instrumentos, contextos e etapas.

Com a preocupação de direcionar a aplicação do Psicodrama na prática educacional, a referida autora, após conhecer o Psicodrama em 1962, em 1969 apresentou o primeiro trabalho, homônimo do livro editado em 1985, onde a mesma enunciava as incursões do Psicodrama na área da educação com a publicação do livro "Psicodrama pedagógico: método educacional psicodramático".

Assim, a partir da década de 80 , essa mentalidade foi amplamente reformulada e novas perspectivas foram se abrindo, de modo que além do cunho psicoterapêutico, o Psicodrama passou a ser empregado em campos diferentes como no setor empresarial ${ }^{(35)}$, em áreas de recursos humanos $^{(36,37,38)}$, no ensino de Enfermagem ${ }^{(39,40,41,42,43,44)}$, na 
pesquisa ${ }^{(45,46,47), \quad \text { além da Psicologia }}{ }^{(48,49)}$, Engenharia ${ }^{(50,51,52)}$, Medicina $^{(53,54,55,56,57,58)}$, entre outras.

Quadro 2- Estrutura do Psicodrama Pedagógico segundo a integração de valores e habilidades, São Paulo - 2007.

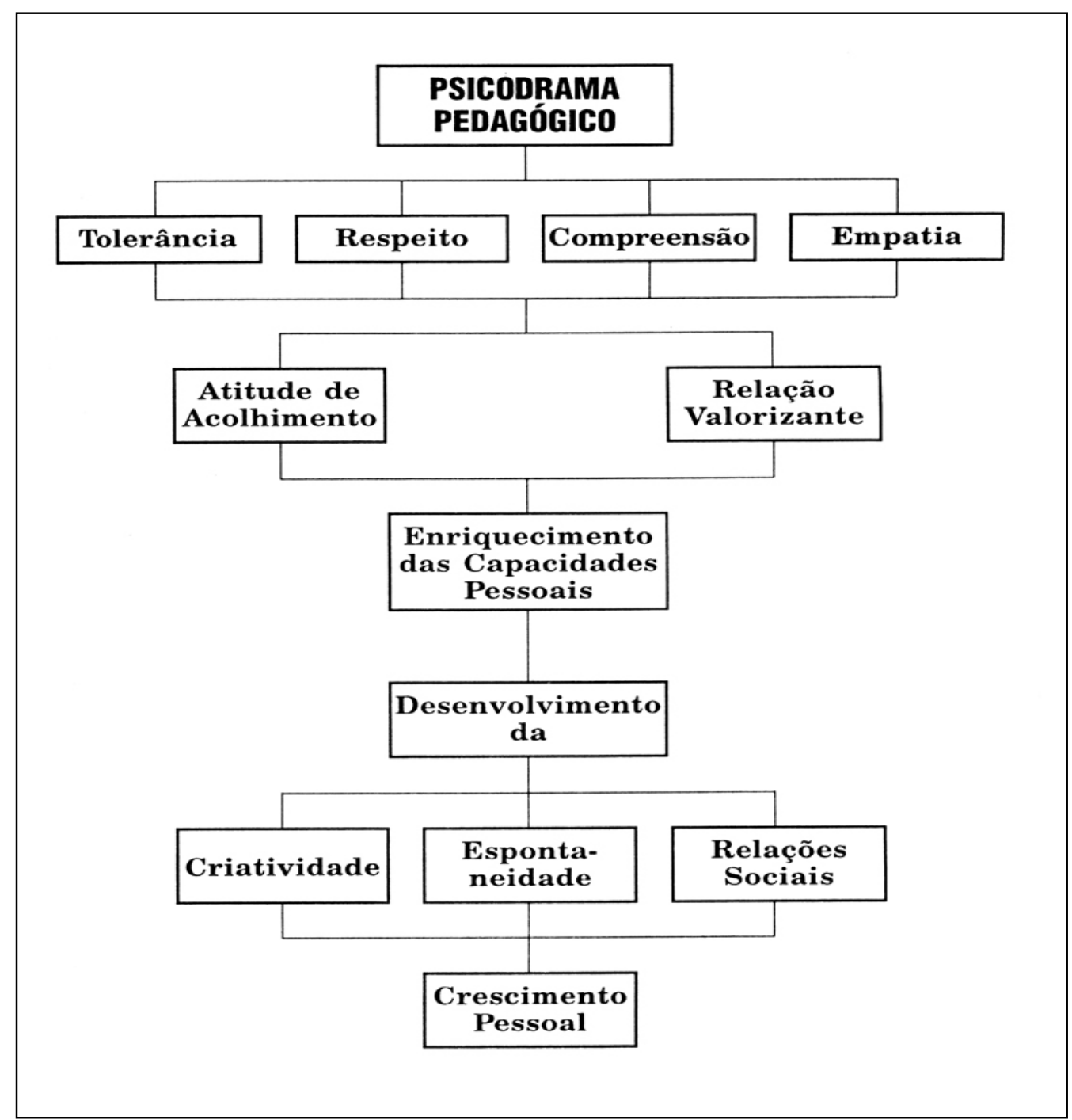

Fonte: Psicodrama em sala de aula. Taís Lima. São Paulo: Vetor; 1998.

No Quadro 2 identificamos a estrutura do Psicodrama Pedagógico, e segundo Romaña ${ }^{(59)}$, "é um método ativo em que o aluno incorpora o conhecimento simultaneamente à aplicação, por meio de vivência, integrando o estado afetivo-emocional e o conteúdo a ser aprendido, 
mantendo o cuidado no limite do afeto para que a relação professor-aluno não supere a relação aluno-conhecimento".

Algumas modificações podem ser verificadas na aplicação do Psicodrama Pedagógico, conforme os objetivos do aplicador, o local, os sujeitos do processo. Porém, a aplicação de maneira não comprometida com nenhuma modalidade em especial, com estilo repetitivo e autoritário em alguns casos, escudada pelo objetivo de desenvolver a criatividade, gerou um sentimento de perplexidade na referida autora, provocando-lhe profundas reflexões. Aliado a essas inquietações, aspirando à criação de valores e ao desenvolvimento de um pensar e de um agir coerentes, Romaña ${ }^{(60)}$ percebeu o sofrimento do panorama educacional em conseqüência do avanço das políticas neoliberais e do capitalismo globalizado; verificou também a falta de um referencial ante aos desejos dos profissionais desenvolverem um tipo de trabalho não-clínico no Psicodrama.

A reflexão sobre esses aspectos reforçou a necessidade de desvendar a natureza do saber e utilizar uma metodologia de ensino democrática e participativa. Então, a partir do Psicodrama Pedagógico, originou-se a Pedagogia do Drama ${ }^{(61)}$, evidenciando um grande interesse em produzir alternativas didáticas criativas, com a participação de todos os envolvidos no processo educativo, por meio do diálogo e da elaboração de projetos que poderão constituir-se em novas mediações socioculturais.

A Pedagogia do Drama é uma proposta de caráter construtivista sustentada por três pilares: a teoria sócio-histórica de Lev Seminovich Vygotsky, a ética da Pedagogia da Autonomia de Paulo Freire e uma didática sociopsicodramática inspirada na obra de Jacob Levy Moreno. Há uma sintonia entre os três autores na delicadeza de aproximação dos fenômenos estudados ou pesquisados. Tal aproximação cuidadosa "incorpora elementos pragmáticos, dialéticos, existenciais e fenomenológicos, pois Vygotsky e Freire postulam uma equação libertadora entre o desenvolvimento da consciência e o fato de converter-se em sujeitos protagonistas da sua história, enquanto Moreno apregoa a necessidade do 
ser humano recuperar sua espontaneidade e criatividade para constituir-se em dono de suas escolhas" (60).

Essa proposta educacional procura vincular os saberes que 0 aprendizado formal oferece com as experiências de vida do estudante e se servir dos recursos sociopsicodramáticos que passam a compor a sua metodologia como elementos facilitadores desse processo, propondo-se a colaborar no desenvolvimento de uma consciência crítica e reflexiva a fim de obter uma compreensão do mundo e suas contingências, com autonomia e responsabilidade.

Quadro 3- Quadro comparativo entre o Psicodrama Pedagógico e a Pedagogia do Drama, São Paulo - 2007.
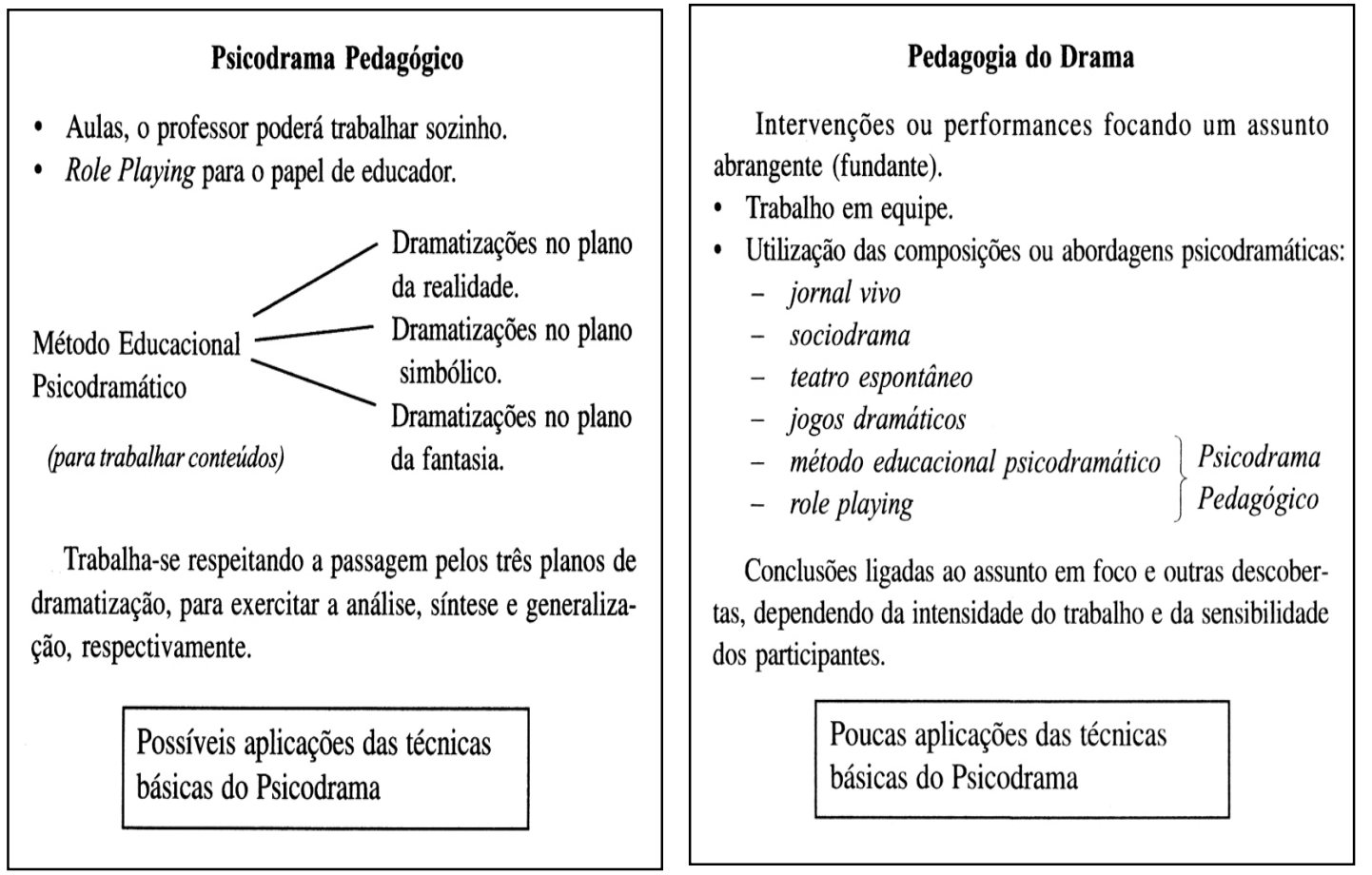

Fonte: Pedagogia do drama: 8 perguntas \& 3 relatos. Maria Alicia Romaña. São Paulo: Casa do Psicólogo; 2004.

Ainda que o Psicodrama Pedagógico seja parte da Pedagogia do Drama, Romaña ${ }^{(61)}$ esclarece que guardam algumas semelhanças entre si, conforme o quadro acima, sendo a última uma expressão mais evoluída em relação ao primeiro. 
O Psicodrama Pedagógico é compreendido como método educacional psicodramático para trabalhar conteúdos e sua representação respeita a passagem em três níveis. O primeiro nível corresponde à dramatização no plano da realidade, situando-se no plano de experiência dos alunos que expressam o que sabem ou sentem em relação ao tema; tem como foco central estimular os educandos para o exercício da análise. O segundo nível é a dramatização no plano simbólico, com os alunos elaborando conceitualmente o conteúdo proposto e expressando o que compreenderam sobre o tema; sua proposta é exercitar a capacidade de síntese dos alunos. E, no último nível, ocorre a dramatização no plano da fantasia com o aluno partindo de um conhecimento prévio do tema, já assegurado em momentos anteriores, e aplicando-o em situações diferentes e criando situações novas; essa etapa final equivale à generalização resultante das soluções próprias construídas e embasadas na reflexão dos saberes apreendidos.

Na Pedagogia do Drama, estabelecem-se as especificações entre as denominadas técnicas básicas ou primárias do Psicodrama e as composições psicodramáticas ou técnicas secundárias. As técnicas básicas ou primárias estão relacionadas com as técnicas de solilóquio (um monólogo, como emitir um pensamento em voz alta), inversão de papéis (troca de papéis entre os participantes da atividade) e interpolação de resistências (mudança brusca ocasionada pela inclusão de fatos ou condições imprevistas em que os participantes se deparam com dificuldades inesperadas). As composições psicodramáticas ou técnicas secundárias estão relacionadas com o role playing, o sociodrama, os jogos dramáticos, o jornal vivo e o teatro espontâneo, e são, técnica e metodologicamente, mais complexas, nelas podendo ser utilizadas as técnicas básicas.

As atividades representativas da Pedagogia do Drama avançam por um roteiro que obedece aos seguintes momentos ${ }^{(60)}$ :

a) contextualização do conteúdo a ser abordado;

b) atividade (s) que promova $(\mathrm{m})$ o aquecimento dos participantes na direção do saber que será construído; 
c) apresentação dramática do assunto (teatro espontâneo, jornal vivo, vivência sociodramática ou performance);

d) inserção dos participantes em atividades interligadas;

e) encerramento com comentários e reflexões, reforçando os propósitos a serem alcançados, esclarecendo as dúvidas eventuais dos participantes.

A contextualização do conteúdo é prevista desde o momento em que se estabelece o planejamento inicial dos trabalhos ou das aulas, com a definição da população a ser envolvida, dos objetivos a serem alcançados, da temática a ser abordada. É recomendável que haja flexibilidade na condução das propostas, considerando-se as características do grupo, estimulando o trabalho em equipe. Ao salientar a importância do tema a ser estudado, o docente desperta o interesse de todos os participantes; sentindo-se motivados, o envolvimento torna-se efetivo, elevando a produtividade do grupo.

São denominados participantes o aluno, o grupo ou a classe, que apresenta o problema ou o tema a ser abordado; o professor, que proporciona a orientação necessária e esclarecedora; a platéia, que é composta pelas pessoas que assistem à apresentação, espectadores atentos ao que está acontecendo.

O aquecimento é o momento preparatório para a apresentação. Nessa etapa, o aluno toma conhecimento da atividade proposta, dos objetivos, dos conteúdos a serem abordados; por meio de estudos e de pesquisas, faz uma análise para acomodação prévia dos conhecimentos e de si mesmo na nova situação.

A dramatização é a ação realizada pelo(s) sujeito(s) durante a interpretação; nesse momento, abandona seu próprio papel como aluno e assume o papel do personagem proposto na estória. No cenário preparado, os personagens entram em cena comentando, refletindo, expressando a mensagem. Nessa etapa, é desejável que a interferência do professor seja a menor possível para não prejudicar a espontaneidade, a criatividade e o 
ritmo da apresentação. A atividade se desenvolve dentro de um cenário que é o espaço escolhido para a apresentação. A disposição dos participantes na atividade é importante para favorecer a integração com os espectadores; o posicionamento das pessoas fica a critério do grupo que irá apresentar o trabalho, mais comumente optando por áreas diferentes da localização da platéia ou buscando a interação junto dela. Frequentemente, o grupo atuante fica à frente dos espectadores que, em geral, são dispostos em círculo ou semicírculo, voltando a atenção à apresentação. O tempo destinado a cada etapa varia conforme a disponibilidade e a duração da disciplina ou da aula.

Após a apresentação, o grupo dá por encerrada a encenação e retorna aos seus lugares. Inicia-se a etapa dos comentários com os participantes relatando suas percepções e sentimentos a respeito do trabalho desenvolvido. Cabe ao professor tecer comentários acerca do conteúdo abordado, com clareza e exatidão do saber explicitado; ao promover uma síntese do tema abordado, assegura o objetivo visado. Como um mediador, o educador deve saber identificar os aspectos relevantes no processo educativo e conduzir a atividade da melhor maneira; mas deve também, estar preparado para lidar com as questões eventuais ou situações inesperadas e tomar as devidas precauções para evitar julgamentos tendenciosos e discriminatórios. É desejável que ele tenha a sensibilidade para leva-lo a valorizar cada aspecto, a reconhecer aspectos positivos naqueles aparentemente considerados negativos e, com maestria, evidenciá-los de forma construtiva.

Os recursos a serem utilizados permitem uma gama de variações, dependendo da disponibilidade no momento, dos recursos financeiros, da criatividade dos participantes. Podem ser utilizados materiais recicláveis, almofadas e outros. O figurino, cenário, sonoplastia, iluminação propostos refletem as experiências de vida, habilidades e características pessoais dos participantes, tornando cada apresentação uma experiência única. Músicas, poesias, objetos e instrumentos de manifestação cultural podem ser agregados, fortalecendo a mediação e a contextualização do tema a ser abordado. 
Sellers ${ }^{(62)}$ afirma que a dramatização é uma estratégia de ensino eficaz no ensino de adultos, pois, ao assumir outros papéis, o indivíduo associa o conhecimento com as situações da vida real, desencadeando um processo de aprendizagem ativo e de envolvimento. A autora sugere que a atividade seja cuidadosamente planejada em sua fase inicial, com orientação aos estudantes sobre os objetivos propostos. Ao ser conduzida por educadores habilidosos que estimulam e discutem o conteúdo a ser abordado, os alunos assumem os novos papéis ao dramatizar a situação criada. Para concluir o processo de modo efetivo, é necessário, ao final, realizar uma revisão cuidadosa, analisando o que foi apresentado e os aspectos que podem ser depreendidos dessa atividade em relação ao conhecimento adquirido, as dúvidas, os comentários e os demais esclarecimentos que se fizerem necessários.

Nesse sentido, é possível utilizar a dramatização como um recurso que pode ser adaptado conforme o grau de compreensão do estudante de Enfermagem, independente do conteúdo a ser abordado ou do grau de complexidade. Compete ao professor a responsabilidade de orientar e direcionar os alunos quanto à adequação e relevância dos assuntos estudados. Ao mencionar a possibilidade de aplicar a dramatização na realização das atividades escolares, Coelho ${ }^{(63)}$ destaca o favorecimento da integração disciplinar, ou interdisciplinaridade, de maneira que o jogo pode ser desenvolvido a partir dos diferentes conteúdos que compõem o currículo, permitindo que o participante coloque em prática o raciocínio e os saberes para a resolução dos problemas.

Esse exercício propicia o desenvolvimento de uma consciência própria e de grupo quanto à forma de expressão, favorecendo aspectos da criatividade e senso do trabalho coletivo do futuro profissional em Enfermagem, uma vez que não só o saber saber é contemplado, mas também, o conjunto de outros saberes fundamentais à competência profissional, que são o saber fazer, o saber ser e o saber conviver. Esses saberes são construídos gradativamente, à medida que o aluno participa das atividades propostas criando seu caminho até o novo conhecimento. 
Sellers ${ }^{(62)}$ ressalta que, "embora os alunos avaliem a dramatização de forma positiva, inicialmente alguns estudantes podem expressar uma preocupação sobre a necessidade de conhecimento do tema abordado e o receio de não corresponder adequadamente ao objetivo proposto".

Considerando que a capacidade de dramatizar é uma questão individual, é compreensível que o estudante manifeste certo desconforto ao ser solicitado para a exposição. Essa resistência inicial pode ser decorrente de fatores diversos, como timidez, medo da exposição, insegurança por não acreditar no próprio potencial, não perceber a seriedade do aprendizado em uma atividade mais descontraída e lúdica.

Quanto a esse aspecto, é importante lembrar que o educador deve ter consciência das eventuais dificuldades do estudante e que essa estratégia tem por finalidade facilitar a aprendizagem dele e não torná-lo um mero ator, pois, a extroversão do indivíduo não deve ser mais importante do que a aprendizagem. Ao aplicar a dramatização como estratégia de ensino, o professor visa principalmente à relação de aprendizagem e a construção do saber, sendo, pois, de grande importância a fundamentação teórica do conteúdo abordado. Entretanto, à medida que cada elemento do grupo passa a se conhecer melhor em sua individualidade, a construção de um trabalho coletivo com um objetivo comum proporciona valiosa experiência ao futuro profissional e cidadão, por ser desenvolvida de forma mais lúdica e descontraída, tornando-se prazerosa.

Romaña ${ }^{(34)}$ comenta que, às vezes, há dificuldade na apreensão desse conhecimento pelo sujeito e enfatiza a importância da motivação do aluno durante o processo. A participação entusiasmada do aluno é fator determinante para mantê-lo interessado e envolvido na atividade.

Nesse sentido, a atuação do professor como incentivador ao adotar estratégias facilitadoras do ensino tem papel relevante como fator motivacional ${ }^{(64)}$. É desejável que a interação em sala de aula ocorra numa dinâmica de envolvimento e interesse, propiciando a liberdade e a troca de experiências entre os estudantes. O educador não deve se deter apenas em 
codificar sua mensagem, precisa ter a capacidade de perceber a reação do outro, ser uma pessoa sensível nas relações humanas e estimular o educando a expressar a sua mensagem ${ }^{(65)}$.

Um ambiente descontraído pode ser obtido com os jogos dramáticos que se transformam, por um momento, em metas que ao serem instrumentalizadas, voltam a ser novamente meios. Nesse tipo de aprendizagem, com a instrumentação sendo praticamente imediata e vivencial, o conhecimento tende a ser assimilado com maior facilidade e incorporado como um elemento próprio.

“... quando a pessoa se sente emocionalmente segura e tranqüila, aprende com facilidade e mais rapidamente. Os sentimentos negativos prejudicam a situação de aprendizagem, absorvendo a energia que poderia ser canalizada para aprender, desviando-a para o controle do estado emocional em desequilibrio”. Brasil

Assim, é essencial olhar para o estudante de forma sensível, preservando a sua identidade e enxergando os seus valores para, então, desenvolver uma linha de trabalho que seja significativa de forma a envolvêlo e motivá-lo no processo de aprendizagem. Nesse percurso, à medida que cada elemento do grupo passa a se conhecer melhor em sua individualidade, a construção de um trabalho coletivo com um objetivo comum transforma-se em valiosa experiência para o futuro profissional.

O jogo dramático estimula, assim, o aprendizado, a criatividade e a comunicação interpessoal no grupo, com a exposição de diferentes experiências e opiniões, externando o respeito pela individualidade de cada estudante. O desenvolvimento do pensamento crítico e do senso de responsabilidade do próprio aluno no processo ensino aprendizagem permite a utilização da dramatização como um instrumento de avaliação ${ }^{(62)}$.

Wasilko (66) reforça que a dramatização enquanto instrumento educativo potencializa a capacidade criativa e que a alternância dos papéis (ator / espectador) nas diferentes situações confere oportunidades para a análise e reflexão, conduzindo a novas perspectivas em seus objetivos. A 
autora elenca diversos aspectos da dramatização no processo ensinoaprendizagem, como o estímulo da imaginação e das emoções, um contexto problematizador que provoca a mobilização de potencialidades e a capacidade para a resolução dos problemas por meio do trabalho em grupo. Esse processo melhora a habilidade de relacionamento interpessoal e de inteligência emocional, gerando uma prática profissional reflexiva construída em conjunto com o crescimento pessoal. Perante a responsabilidade do educador em conduzir o processo e estabelecer os limites nele requeridos, essa autora recomenda que os educadores, ao utilizarem a dramatização, tenham um preparo adequado que lhes permita direcionarem a aprendizagem do aluno para o objetivo desta estratégia de ensino.

Apesar desta estratégia de ensino estar sendo incorporada gradativamente à vivência dos docentes de Enfermagem, Sellers ${ }^{(62)}$ relata que não há na literatura em relativa à Enfermagem, uma discussão sobre a utilização, na formação profissional, da dramatização como estratégia no processo educativo que pode ser efetivamente aplicada.

Esta inquietação frente a duas situações conflitantes sobre haver ou não referências sobre a dramatização como estratégia facilitadora e buscando aumentar os conhecimentos diante das inúmeras possibilidades de sua aplicação no processo ensino aprendizagem, despertou-nos o interesse em verificar as evidências sobre a utilização da dramatização como estratégia educacional em Enfermagem, através de uma revisão sistemática.

De acordo com o Centre for Reviews and Dissemination ${ }^{(67)}$ a decisão de realizar esse tipo de revisão deve ser precedida de uma investigação com o intuito de identificar a existência ou não de uma revisão similar a fim de evitar esforços desnecessários. Previamente ao início deste trabalho, foi realizado um levantamento através de uma busca nas diversas bases de dados eletrônicos existentes, para verificar se havia algum trabalho semelhante ao presente estudo. 
Não foi encontrada nenhuma revisão sistemática sobre o tema, o que nos permitiu iniciar esta pesquisa, que tem como proposta identificar as evidências científicas existentes sobre a aplicação da dramatização e verificar a sua influência no processo de ensino e aprendizagem na Enfermagem, orientada pela questão norteadora:

"Quais os resultados da aplicação da dramatização na aprendizagem do estudante de Enfermagem?" 


\section{OBJETIVOS}




\section{OBJETIVOS}

- Levantar os estudos relativos à aplicação da dramatização como estratégia no processo de ensino e aprendizagem na formação profissional em Enfermagem.

- Verificar os resultados da utilização dessa estratégia na aprendizagem do estudante de Enfermagem. 


\section{TRAJETÓRIA METODOLÓGICA}




\section{TRAJETÓRIA METODOLÓGICA}

Trata-se de uma pesquisa de caráter não-experimental que utiliza o método de revisão sistemática da literatura.

Hulley et al. ${ }^{(68)}$ relatam que a revisão sistemática utiliza os estudos primários como sujeitos da investigação através de métodos sistemáticos e predefinidos que auxiliam na explicação de diferenças encontradas nesses estudos ao pesquisar determinado assunto. Dessa maneira, capacitam os pesquisadores a realizarem uma avaliação das evidências disponíveis na literatura, em particular na área da prática clínica, pois o conhecimento adquirido nessa pesquisa contribuirá para o tratamento e a implementação de intervenções para melhorar a assistência à saúde.

Ao contrário das demais pesquisas que examinam a literatura, as revisões sistemáticas utilizam uma abordagem bem definida e uniforme para identificar todos os estudos relevantes e mostrar os resultados dos estudos elegíveis. Quando apropriado, pode-se calcular uma estimativa-sumário dos resultados globais e, a esse aspecto estatístico, denomina-se metanálise.

Através das investigações científicas com métodos planejados antecipadamente com a finalidade de reunir os originais e os seus "sujeitos", a revisão sistemática resume os resultados de múltiplas investigações primárias, utilizando estratégias que restrinjam os vieses e os erros randomizados, e essas, além de inserirem numa abrangente pesquisa todos os artigos relevantes, informam os critérios utilizados na seleção dos mesmos, tornando a investigação reprodutível.

Segundo Galvão, Sawada e Trevisan ${ }^{(69)}$, os ensaios clínicos controlados fornecem as melhores evidências, sendo seu uso, portanto, considerado mais seguro. Entretanto, em razão das diversas características que permeiam as atividades em Enfermagem, as múltiplas faces nessa área 
nos remetem a planos mais subjetivos, inerentes a todo processo voltado para o ser humano ${ }^{(*)}$.

$\mathrm{Na}$ presente pesquisa, onde relacionamos o ensino e a formação profissional em Enfermagem, o foco clínico na acepção da palavra não foi o mais relevante, pois, na área de educação em saúde, não é freqüente encontrarmos referências sobre a realização de estudos experimentais, em razão da subjetividade que norteia a nossa investigação. Entretanto, verificamos que os profissionais de Enfermagem têm desenvolvido estudos utilizando a revisão sistemática com o propósito de responder às questões que possam ser aplicadas no desenvolvimento de seus trabalhos, identificando aspectos positivos e negativos de diferentes intervenções na atuação da enfermagem, através da prática baseada em evidências científicas.

Conforme as descrições do Centro Cochrane do Brasil ${ }^{(70)}$, adotadas no presente estudo, os passos que conduzem ao processo de revisão sistemática podem ser assim sintetizados: 1) formulação de uma questão de pesquisa; 2) busca na literatura para identificar o tema escolhido; 3) verificação prévia da existência de alguma revisão similar; 4) busca abrangente para seleção dos estudos a serem incluídos na revisão, seguindo critérios inicialmente estabelecidos (protocolo); 5) coleta de dados através dos estudos selecionados; 6) análise e síntese dos dados com o resumo narrativo e a apresentação dos resultados e/ou com o emprego de métodos estatísticos, como a metanálise que consiste na análise estatística secundária dos resultados de estudos similares, ampliando a crítica e as indagações dela provenientes. Porém, nem sempre essa análise é possível devido ao número escasso de pesquisas em determinadas áreas do conhecimento.

É importante ressaltar que diretrizes rigorosas devem ser estabelecidas para cada passo, com a elaboração de um protocolo

*Evidence Based Nursing. http://ebn.bmj.com/ 
transparente para que o estudo seja reprodutível a fim de eliminar vieses e assegurar rigor científico à pesquisa.

\section{$3.1 \quad$ AMOSTRA}

A amostra é do tipo não probabilística, de conveniência, constituída por publicações, nacional e internacionalmente indexadas nas bases de dados mais abrangentes, sobre a utilização da dramatização no processo de ensino e aprendizagem em Enfermagem.

O levantamento bibliográfico foi realizado nas bases de dados: LILACS, MEDLINE, CINAHL, EMBASE, ERIC, PAHO, WHOLIS, USP/Sibi-DEDALUS, PERIENF, BDENF.

\subsection{CRITÉRIOS DE INCLUSÃO}

$\mathrm{Na}$ consulta aos bancos de dados, foram adotados como critérios de inclusão: os estudos publicados em periódicos nacionais e internacionais, relativos ao tema propostos e cujos conteúdos continham informações relevantes para o escopo desta pesquisa.

Não se estabeleceu um limite na dimensão temporal quanto ao ano de publicação dos estudos para não diminuir a sensibilidade das buscas.

\subsection{CRITÉRIOS DE EXCLUSÃO}

Foram excluídas as publicações apresentadas como cartas e editoriais, os artigos cuja população não era relacionada com os estudantes 
de Enfermagem, os estudos relacionados com profissionais e estudantes de outras áreas distintas da Enfermagem.

\subsection{CONSTRUINDO A REVISÃO SISTEMÁTICA}

O levantamento dos estudos ocorreu no período de janeiro a setembro de 2006.

A seguir, apresentam-se as etapas percorridas na elaboração desta revisão sistemática, conforme as descrições do Centro Cochrane do Brasil (74).

\section{Etapa: Formulação da questão norteadora da pesquisa}

A prática baseada em evidências leva em consideração a necessidade de admitir a existência de conhecimentos explícitos e tácitos, entendendo que é impossível tornar explícitos todos os aspectos da competência profissional. A dúvida passa a fazer parte do processo de decisão; inicialmente, na identificação dos componentes inconscientes envolvidos e, em seguida, na análise do conhecimento explícito utilizado nesse processo.

Nobre ${ }^{(71)}$ comenta que as decisões tomadas para resolver 0 problema do cliente são, usualmente, baseadas na aplicação consciente da informação avaliável por regras explicitamente definidas. Essa forma de conhecimento explícito pode ser quantificada, modelada, prontamente comunicada e facilmente transposta para diretrizes de condutas baseadas em evidência.

No entanto, uma grande quantidade de conhecimento tácito, experiência, valores e habilidades constitui um tipo diferente de evidência e tem uma forte influência na tomada de decisão. Enquanto os elementos 
explícitos são ensinados formalmente, os tácitos são adquiridos durante a observação e a vivência. Exige-se, então, do profissional uma prática reflexiva e cuidadosa, pois a identificação da dúvida caminha com o objetivo de corrigir desvios e distorções na busca da melhor opção.

A decisão de iniciar a busca por essas opções é deflagrada pelas inquietações frente a determinado assunto e ao modo como proceder para encontrar as evidências relacionadas. O momento seguinte consiste na formulação de uma pergunta que traga para si as melhores respostas sobre o tema. Entretanto, em face da possibilidade de erros pela subjetividade do pesquisador e pelos vieses tanto da pesquisa a ser iniciada quanto do estudo já concluído e "sujeito" da revisão, alguns aspectos devem ser observados na construção dessa questão para que os resultados da investigação sejam coerentes com o objetivo inicial.

A questão que constitui objeto de pesquisa deve ser clara, descrever a condição de interesse, a população e o contexto, a intervenção e o desfecho de interesse. Ao ser formulada a questão deve ser estruturada de maneira que possa ser respondida; lembra que essa dúvida pode estar relacionada com aspectos básicos e de definição do tema em questão, como o assunto a ser abordado. Esse pode ser a aprendizagem, o comportamento, a assistência de Enfermagem, o procedimento, a doença ou pode estar relacionada com o atendimento do cliente, quanto ao diagnóstico, à terapêutica ou ao prognóstico.

Essa questão pode ser classificada em: básica (background) e clínica (foreground). As perguntas advindas de questões básicas referem-se à etiologia, etiopatogenia, fisiopatologia, epidemiologia e não envolvem o manuseio dos pacientes. Possuem como características principais um pronome ou advérbio interrogativo associado a um verbo, determinando a raiz da questão (por que, como, quando, onde, quem, o que, qual), relacionando com uma doença ou condição a ser investigada.

A questão clínica enfoca o conhecimento a respeito do tema. Seus componentes principais são: o cliente ou problema de interesse; a 
intervenção principal; uma intervenção de comparação, quando cabível; os desfechos de interesse. Essas questões abordam claramente os aspectos da intervenção aplicável a uma determinada condição.

Como o tema pode ser muito amplo, é necessário dirigir o foco do estudo para uma condição especial a ser investigada. É desejável que ela não seja demasiadamente genérica ou extremamente específica a fim de não comprometer os achados e resultados finais.

O processo para encontrar as respostas apropriadas das investigações depende da estruturação dos elementos da questão. A forma preconizada é conhecida pela sigla PICO: $\mathrm{P}$ é relacionado ao paciente ou população a ser estudada; I está associado à intervenção ou indicador; C refere-se à comparação ou ao controle; O relaciona-se com o desfecho, resultado, a resposta que se espera encontrar nas fontes de informação científica ${ }^{(72)}$. Dependendo do tema a ser estudado e das respostas possíveis de serem encontradas, um ou outro campo pode ficar em aberto, ou seja, não é imprescindível que todos os quatro campos sejam preenchidos, desde que não haja comprometimento das buscas como limitação da abrangência e perda da sensibilidade.

Transportando a estruturação dos elementos da questão desse referencial teórico para o presente estudo, podemos situar o processo da seguinte maneira: $\mathbf{P}$ está relacionado com estudantes de enfermagem; I está associado com a dramatização; C refere-se à comparação, e a nossa intenção foi promover uma busca ampla sem objetivos comparativos; portanto, nada foi especificado nesse campo; 0 relaciona-se com conhecimento ${ }^{(*)}$.

Assim, a pergunta elaborada como questão norteadora para a presente investigação foi: "Quais os resultados da aplicação da dramatização na aprendizagem do estudante de Enfermagem?'.

\footnotetext{
* http://pubmedhh.nlm.nih.gov/nlm/pico/piconew.html
} 


\section{$2^{a}$. Etapa: A revisão nas bases de dados}

Após a identificação da questão de interesse da pesquisa, realizou-se uma busca preliminar para verificar se havia alguma revisão sistemática a respeito da dramatização. Acessando os seguintes bancos eletrônicos: Medline; Center for Evidence Based Nursing (University of York, Reino Unido), Centre for Reviews and Dissemination (CRD) e Cochrane Database of Systematic Reviews (CDSR), verificou-se que nenhum estudo semelhante fora descrito.

Satisfeita essa condição básica para que a revisão pudesse ser concretizada, o passo seguinte foi encontrar as palavras chaves que melhor descrevessem cada uma das características da questão norteadora. Sem tais cuidados, corre-se o risco das pesquisas em bases de dados informatizadas resultarem em ausência ou em excesso de informações não relacionadas com o assunto de interesse.

Para o direcionamento da busca nessas bases foram identificados, através do DeCS/ MeSH, os descritores relacionados com a questão do estudo: nursing education; nursing students; role playing; psychodrama; simulation.

Os descritores selecionados foram baseados na área de interesse deste estudo (educação em enfermagem), no alvo a ser estudado (estudantes de enfermagem) e no termo correspondente ao tema central desta pesquisa (dramatização).

Através de um levantamento prévio e leitura dos estudos publicados, percebemos que, não raro, eram utilizados os termos psicodrama e simulação em alusão à utilização da dramatização. Entretanto, numa pesquisa inicial, verificamos que o emprego dos descritores correspondentes trazia consigo uma grande quantidade de estudos não relacionados com o escopo da pesquisa. $O$ descritor simulation freqüentemente estava associado ao uso de computador, tecnologia na educação e simulações de situações em que o aluno resolve os casos delineados no software 
educacional. Porém, com o intuito de manter a sensibilidade da busca, a fim de não excluir estudos relevantes a esta pesquisa, esses descritores foram mantidos em nossa investigação.

Outro aspecto observado diz respeito à maneira como as buscas são efetuadas. Por vezes, ao utilizar os operadores booleanos e a expressão desejada, é recomendável, conforme a base de dados, escrever as expressões compostas entre aspas ou entre parênteses para especificar as buscas, senão corre-se o risco de encontrar uma quantidade de informações que podem, em sua maioria, ser inúteis. Apesar desse cuidado, depreendeuse que não há uma padronização entre as diferentes bases de dados, o que exige do pesquisador um esforço no sentido de organizar as buscas de modos sensivelmente diferentes, conforme a base em questão, por ser essencial uma busca abrangente na literatura que assegure a identificação dos estudos sobre o tema em foco.

Prosseguiu-se, então, com as buscas orientadas pelos descritores selecionados e foram utilizadas as bases MEDLINE, EMBASE, CINAHL, ERIC, LILACS, WHOLIS, PAHO, USP/Sibi-DEDALUS, PERIENF, BDENF.

O levantamento e identificação de estudos de interesse também foram baseados em buscas manuais, visando a localizar trabalhos relevantes. A verificação das referências bibliográficas dos estudos, ainda que excluídos, pode ser de grande valia, pois, dentre essas referências, podemos encontrar trabalhos relevantes a serem incluídos.

Desse modo, é necessário seguir uma estratégia bem definida, estabelecida antes de iniciar as buscas. Os estudos selecionados devem, primeiramente, satisfazer os critérios de inclusão na pesquisa e a elaboração de um instrumento protocolar auxilia na verificação de cada estudo.

No protocolo de busca construído, constavam os seguintes dados (Apêndice):

- autor: nome; 
- estudo: título; ano; identificação da população; área de estudo; escopo do trabalho; desenho metodológico; resultados e conclusões;

- fonte: nome, ano, volume, número, país.

\section{$3^{\text {a }}$. Etapa: Identificação dos estudos a serem incluídos na revisão}

Durante a busca em bases de dados eletrônicas, diversos estudos foram identificados. Essa etapa do processo propiciou a avaliação das informações e a relevância dos estudos referentes à questão da pesquisa.

As informações podem ser classificadas em primárias ou secundárias, segundo Bernardo ${ }^{(73)}$. As primárias referem-se aos trabalhos originais, publicados na íntegra ou em forma de resumo; são úteis para a localização de informações no desenvolvimento de trabalhos de pesquisa, elaboração de diretrizes ou divulgação científica. As secundárias são as informações reproduzidas a partir do original, comentadas e avaliadas criticamente; são de aplicação prática porque, apesar de não exigirem muito tempo de investigação, fornecem informações confiáveis, pois já foram analisadas e avaliadas anteriormente.

A opção do pesquisador pelos tipos de informações que irá utilizar depende de alguns aspectos, como as características do assunto a ser investigado, necessidade de informações mais recentes, disponibilidade de tempo para análise e avaliação dos resultados.

A organização dos estudos selecionados pode ser viabilizada utilizando softwares como ferramentas para criar um arquivo eletrônico próprio. Existem disponíveis várias opções de softwares como o EndNote, Reference Manager, ProCite, RevMan, Refworks.

Em virtude da facilidade de aquisição, de aplicação e principalmente pela disponibilidade na maioria das bases eletrônicas, foi utilizado o EndNote 9 . Esse software auxiliou na importação e transferência direta dos 
estudos selecionados da base de dados pesquisada para o arquivo pessoal da pesquisadora, onde foi criada uma "biblioteca individual" contendo os estudos encontrados, de maneira a serem catalogados com dados de identificação, os quais favoreceram o acesso sempre que necessário, além de possibilitar a criação de filtros específicos conforme as necessidades do pesquisador. Lembramos que não são todas as bases de dados que permitem essa conexão direta através do software, sendo necessários, então, cuidados específicos na importação e transferência do artigo encontrado, incluindo os dados informativos de interesse do pesquisador, previstos no protocolo de busca.

\section{Etapa: Seleção e avaliação dos estudos encontrados}

É recomendável avaliar criteriosamente cada estudo encontrado, considerando-se a adequação ao escopo da pesquisa e as características metodológicas, para que estudos relevantes possam indicar os caminhos percorridos pelos estudiosos da dramatização, bem como os resultados dessas investigações que fornecerão as evidências científicas quanto à utilização dessa estratégia.

A consistência dos estudos, segundo Sackett ${ }^{(74)}$, está relacionada com vários fatores; entre eles, a avaliação crítica e adequação dos componentes do desenho da pesquisa, como a característica, o tamanho e a randomização da amostra; o cegamento em estudos comparativos; a validação dos resultados; o período de duração da pesquisa; as perdas significativas da amostra e o prejuízo nos achados finais. Outro aspecto a ser considerado é o tipo de estudo. Em geral, o delineamento por relato de caso e controle implica a geração de hipóteses; estudos transversais, de coorte e caso controle podem comprovar associações; ensaio clínico randomizado e coorte podem estabelecer o vínculo entre causa e efeito. Assim, cada desenho metodológico traz consigo a força da pesquisa. 
Elaborou-se uma etiqueta eletrônica contendo os dados do protocolo para identificar cada estudo digital encontrado. Somente os artigos impressos receberam identificação impressa (Apêndice) contendo os respectivos dados e foram catalogados em uma pasta.

\section{5a. Etapa: Coleta de dados}

A extração dos dados de cada achado deve ser feita de maneira uniforme e livre de vieses. É importante documentar rigorosamente os dados dos estudos a serem incluídos na revisão e que responderão à pergunta da investigação, devendo conter informações relativas ao objetivo, à população, ao delineamento do estudo e aos resultados evidenciados.

O software Access 2003 foi utilizado como ferramenta para criar um banco de dados, constituindo-se no arquivo eletrônico dos estudos encontrados. Permitiu a sua tabulação conforme os critérios de interesse, como: título, autor, fonte, ano de publicação, país, estudos incluídos e excluídos, formato (digital, impresso), definição do status (encontrado, não localizado, aguardando tradução), além dos itens protocolados (identificação da população; área de estudo; escopo do trabalho; desenho metodológico; resultados; conclusões e categorias específicas).

Salientamos a importância da alimentação simultânea dos bancos de dados realizada a cada leitura e decisão da inclusão ou exclusão, evitandose a perda de informações e erros de classificação. Esse tipo de organização facilita o acompanhamento dos achados e a composição do resultado final do trabalho. 


\section{6a. Etapa: Análise e síntese dos dados}

Nesta etapa final, realizou-se a análise dos resultados encontrados em cada estudo e a síntese desses dados, apresentados de maneira clara e objetiva sob a forma de tabelas, gráficos e quadros.

A seguir, no quadro 4 encontram-se listados os 64 estudos incluídos nesta investigação. 
Quadro 4 - Lista dos estudos incluídos, São Paulo - 2007.

\begin{tabular}{|c|c|c|c|c|c|}
\hline Artigo & Objetivo & $\begin{array}{l}\text { Tipo de } \\
\text { estudo }\end{array}$ & Metodologia & Resultados & Área \\
\hline $\begin{array}{l}\text { A dramatização como recurso no } \\
\text { processo ensino aprendizagem na } \\
\text { disciplina de Historia de Enfermagem } \\
\text { Autor: Barros MA Cyrilllo CCP } \\
\text { Fonte: Cogitare Enferm }\end{array}$ & $\begin{array}{l}\text { Conhecer a opinião dos graduandos sobre a } \\
\text { vivência ao participar de uma dramatização. }\end{array}$ & Descritivo & 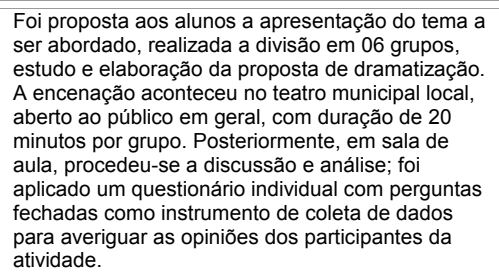 & $\begin{array}{l}\text { Os alunos mostraram-se favoráveis á } \\
\text { utilização da dramatização no } \\
\text { processo ensino aprendizagem, } \\
\text { manifestando a motivação e } \\
\text { satitfacáano em participar da atividade, } \\
\text { a contribuição da mesma no } \\
\text { aprendizado do tema proposto. }\end{array}$ & $\begin{array}{l}\text { História da } \\
\text { Enfermagem }\end{array}$ \\
\hline $\begin{array}{l}\text { Achieving Excellence in End-of-Life Care } \\
\text { Autor: Pimple C, Schmidt L, Tidwell S } \\
\text { Fonte: Nurse Educator }\end{array}$ & $\begin{array}{l}\text { Descrever um programa de um curso relacionado } \\
\text { com cuidados paliativos na fase terminal da vida. }\end{array}$ & Descritivo & $\begin{array}{l}\text { Descrição de um relato de um curso, descrevendo } \\
\text { a importância de preparar os estudantes para lidar } \\
\text { com pacientes na fase terminal da vida e com a } \\
\text { morte. }\end{array}$ & $\begin{array}{l}\text { Relaciona a importância da qualidade } \\
\text { da assistência e da do preparo dos } \\
\text { profissionais. }\end{array}$ & Não especifica \\
\hline $\begin{array}{l}\text { Affective Learning: Stimulus to Critical } \\
\text { Thinking and Caring Practice. } \\
\text { Autor: Zimmerman BJ, Phillips } \mathrm{CY} \\
\text { Fonte: Journal of Nursing Education }\end{array}$ & $\begin{array}{l}\text { Descrever a inclusão de estratégias de ensino } \\
\text { afetiva para conscientizar os estudantes sobre a } \\
\text { importância da assistência holistica ao portador } \\
\text { de doença crônica. }\end{array}$ & Descritivo & $\begin{array}{l}\text { Foi proposto um estudo teérico sobre as doenças } \\
\text { crônicas, foram criadas diversas situaçōes e } \\
\text { dramatizando, os estudantes assumiram o papel } \\
\text { de pacientes portadores de doenças crônicas. }\end{array}$ & $\begin{array}{l}\text { Estímulo a criatividade, melhora do } \\
\text { conhecimento e consciência das } \\
\text { limitações destes pacientes. }\end{array}$ & Reabilitação \\
\hline $\begin{array}{l}\text { Allocation of Resources: A Student } \\
\text { simulation } \\
\text { Autor: Lev EL } \\
\text { Fonte: Nurse Educator }\end{array}$ & $\begin{array}{l}\text { Introduzir o aluno em realidades que envolvem } \\
\text { financiamentos, valores e experiência humana. }\end{array}$ & Descritivo & $\begin{array}{l}\text { Foram envolvidos } 13 \text { estudantes na seleção e } \\
\text { exposição de assuntos, por meio da dramatização, } \\
\text { relacionados à inclusão social. }\end{array}$ & $\begin{array}{l}\text { Positivos, melhora da percepção da } \\
\text { realidade de maneira critica e } \\
\text { reflexiva. }\end{array}$ & Não especifica \\
\hline $\begin{array}{l}\text { An exercise in critical thinking using role } \\
\text { playing } \\
\text { Autor: Jenkins P, Turick-Gibson T } \\
\text { Fonte: Nurse Educator }\end{array}$ & $\begin{array}{l}\text { Utilizar a simulação e dramatização como método } \\
\text { instrucional no ensino de Diabetes. }\end{array}$ & Exploratório & $\begin{array}{l}\text { Foi proposto aos } 34 \text { estudantes de enfermagem a } \\
\text { vivência de situaçóes relacionadas ao cotidiano de } \\
\text { um diabético associando aspectos do autocuidado, } \\
\text { da dieta, submetendo-se aos testes para controle } \\
\text { glicemico. Foram utilizadas estratégias como } \\
\text { simulação e dramatização. }\end{array}$ & $\begin{array}{l}\text { Melhora quanto ao conhecimento, } \\
\text { mudanças quanto às crenças, estilo e } \\
\text { qualidade de vida do diabético, } \\
\text { desenvolvimento do pensamento } \\
\text { critico em relaçãoa às doenças } \\
\text { crônicas. }\end{array}$ & Não especifica \\
\hline $\begin{array}{l}\text { An eye-opening experience: student } \\
\text { exposure to functional disabilities } \\
\text { Autor: Bassett SD, Pickard S } \\
\text { Fonte: Nurse Educator }\end{array}$ & $\begin{array}{l}\text { Conscientizar os alunos sobre as dificuldades dos } \\
\text { clientes com distúrbios funcionais. }\end{array}$ & Descritivo & 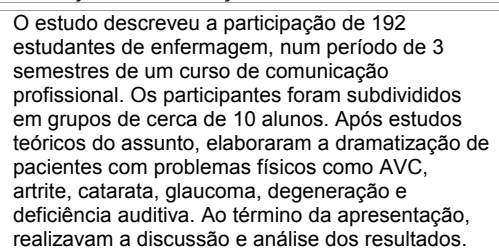 & $\begin{array}{l}\text { Melhora na consciência das } \\
\text { dificuldades dos pacientes com algum } \\
\text { tipo de deficiência fisica, incremento } \\
\text { na visão crítica das necessidades } \\
\text { destes pacientes, fortalecimento das } \\
\text { relaçōes, coleguismo. }\end{array}$ & Não especifica \\
\hline
\end{tabular}


Quadro 4 - Lista dos estudos incluídos, São Paulo - 2007. (continuação)

\begin{tabular}{|c|c|c|c|c|c|}
\hline Artigo & Objetivo & $\begin{array}{l}\text { Tipo de } \\
\text { estudo }\end{array}$ & Metodologia & Resultados & Área \\
\hline $\begin{array}{l}\text { At the learning stage } \\
\text { Autor: : Furland E } \\
\text { Fonte: Nursing Standard }\end{array}$ & $\begin{array}{l}\text { Ajudar os estudantes do último ano do curso de } \\
\text { Obstetricia a lidar com situaçōes que despertam o } \\
\text { senso de responsabilidade e a necessidade de } \\
\text { enfrentamento das dificuldades. }\end{array}$ & Descritivo & $\begin{array}{l}\text { Alunas do curso de Obstetrícia, através do teatro, } \\
\text { procuram mostrar situaçóes os problemas que } \\
\text { podem ocorrer na vida profissional eas maneiras } \\
\text { de enfrentar as dificuldades. Os outros estudantes } \\
\text { representam a "platéia" que assiste as cenas que } \\
\text { se desenrolam no hospital. }\end{array}$ & $\begin{array}{l}\text { As ações dos estudantes tornaram-se } \\
\text { mais assertivas, passando a } \\
\text { administrar as situaçôes adversas de } \\
\text { maneira mais adequada. }\end{array}$ & Saúde da Mulher \\
\hline $\begin{array}{l}\text { Atendimento de enfermagem em saúde } \\
\text { mental em unidade básica de saúde } / \\
\text { Nursing care at mental health in basic unit } \\
\text { of health } \\
\text { Autor: Silva W V } \\
\text { Fonte: Rev Enfermagem UERJ }\end{array}$ & $\begin{array}{l}\text { Relatar uma experiência sobre modificaçōes no } \\
\text { ensino da disciplina Enfermagem Psiquuátrica, } \\
\text { visando incluir a assistenciaia em sauude mental em } \\
\text { uma unidade básica de saúde. }\end{array}$ & Relato de caso & $\begin{array}{l}\text { A autora relata a experiência de introduzir a } \\
\text { abordagem sobre saúde mental na UBS. Para } \\
\text { melhor compreensão por parte dos alunos acerca } \\
\text { da atuação durante o estágio na UBS, foi realizada } \\
\text { a dramatizacacá do atendimento ao cliente. Além } \\
\text { desta ativivadade, foram propostos estudose } \\
\text { seminários. }\end{array}$ & $\begin{array}{l}\text { Os alunos relataram que inicialmente, } \\
\text { sentiram-se pouco a vontade ao } \\
\text { estabelecero os primeiros contatos com } \\
\text { o cliente, porém, superaram a } \\
\text { dificuldade, compreendendo a } \\
\text { importância e a responsabilidade no } \\
\text { compromisso com o cliente. }\end{array}$ & Saúde Mental \\
\hline $\begin{array}{l}\text { Bang the gavel: using a mock trial debate } \\
\text { to teach healthcare delivery perspectives } \\
\text { Autor: Dickerson SS, Jones JM, Sackett } \\
\text { KM } \\
\text { Fonte: Nurse Educator }\end{array}$ & $\begin{array}{l}\text { Utilizar estratégias em sala de aula que estimulem } \\
\text { o pensamento crítico. }\end{array}$ & Exploratório & $\begin{array}{l}\text { Foi proposto aos estudantes o estudo de um tema, } \\
\text { elaboração de um debate e dramatização de } \\
\text { situaçōes, estimulando habilidades } \\
\text { comunicacionais no grupo, atraveses da } \\
\text { argumentação e defesa. }\end{array}$ & $\begin{array}{l}\text { Melhora na capacidade } \\
\text { relacionamento interpessoal, trabalho } \\
\text { em grupo, desenvolvimento do } \\
\text { pensamento crítico. }\end{array}$ & Não especifica \\
\hline $\begin{array}{l}\text { Beyond Content: Generating Critical } \\
\text { Thinking in the Classroom } \\
\text { Autor: Gray MT } \\
\text { Fonte: Nurse Educator }\end{array}$ & Desenvolver habilidades e pensamento crítico. & Descritivo & $\begin{array}{l}\text { Utilização de estratágiasas de ensino como } \\
\text { dramatizacaão e seminário, num curso intitulado } \\
\text { "Trends and Issues in Nursing" sobre as } \\
\text { tendenciass, lançamentos, perspectivas históricas, } \\
\text { conceitos transculturais em enfermagem, entre } \\
\text { outros. }\end{array}$ & $\begin{array}{l}\text { Desenvolvimento do senso de } \\
\text { coletividade e aumento da integração } \\
\text { do grupo, melhora da criatividade e } \\
\text { pensamento crítico. Limitação quanto } \\
\text { à dificuldade do aluno em restringir-se } \\
\text { apenas nas questôes enfocadas para } \\
\text { a discussão. }\end{array}$ & Não especifica \\
\hline $\begin{array}{l}\text { Changing places } \\
\text { Autor: MacArthur J } \\
\text { Fonte: Nursing Standard }\end{array}$ & $\begin{array}{l}\text { Desenvolver habilidades de relacionamento } \\
\text { interpessoal considerando que o profissional de } \\
\text { enfermagem trabalha com uma equipe } \\
\text { multiprofissional. }\end{array}$ & Descritivo & $\begin{array}{l}\text { Os estudantes foram divididos em grupo pequenos } \\
\text { para estudo teórico dramatização de situaçōes } \\
\text { caracteristicas da vida profissional, envolvendo as } \\
\text { relaçếes interpessoais entre diferentes } \\
\text { profissionais. }\end{array}$ & $\begin{array}{l}\text { Maior capacidade de enfrentamento } \\
\text { dos problemas, maior consciência } \\
\text { sobre a capacidade de ser um agente } \\
\text { de transformação no local de trabalho, } \\
\text { sobre as questôes relacionadas ao } \\
\text { paciente. }\end{array}$ & Não especifica \\
\hline $\begin{array}{l}\text { Clinical Preparation for Beginning Nursing } \\
\text { Students: An Experiential Learning Activity } \\
\text { Autor: Ham K, O'Rourke E } \\
\text { Fonte: Nurse Educator }\end{array}$ & $\begin{array}{l}\text { Descrever o desenvolvimento e implementação de } \\
\text { uma atividade de aprendizagem experimental } \\
\text { concebida para estudantes na fase inicial do curso } \\
\text { de enfermagem. }\end{array}$ & Descritivo & $\begin{array}{l}\text { Em um curso composto por um bloco teórico e } \\
\text { prático, são formados grupos de } 3 \text { a } 4 \text { alunnos e } \\
\text { orientadoss sobre uma determinada situaçãa. Após } \\
\text { a preparação, encenam o atendimento ao cliente. } \\
\text { O foco é voltado à abordagem ao cliente, a } \\
\text { realização das técnicas e o aspecto ético } \\
\text { profissional. }\end{array}$ & $\begin{array}{l}\text { Foram positivos quanto ao ganho no } \\
\text { conhecimento, melhora das } \\
\text { habilidades, diminuição da ansiedade, } \\
\text { percepção do cliente como um todo. }\end{array}$ & Não especifica \\
\hline $\begin{array}{l}\text { Communication is the essence of nursing } \\
\text { care. 2: Ethical foundations } \\
\text { Autor: Chauhan } \mathrm{G} \text {, Long } \mathrm{A} \\
\text { Fonte: Br J Nurs }\end{array}$ & $\begin{array}{l}\text { Examinar questões éticas envolvidas ao dizer "a } \\
\text { verdade" ao paciente com relação ao seu estado } \\
\text { de sauude. }\end{array}$ & Descritivo & 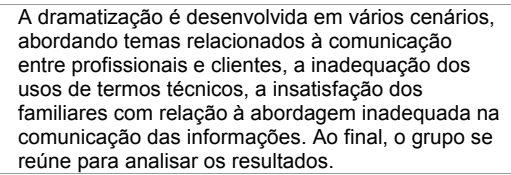 & $\begin{array}{l}\text { Foram considerados pontos } \\
\text { importantes na comunicação com o } \\
\text { paciente: interacãão terapeutitica e ética, } \\
\text { conhecer os limites na abordagem das } \\
\text { informaçōos, não mentir, fornecer } \\
\text { todas as informaçōes para que } \\
\text { possam tomar suas próprias decisões. }\end{array}$ & Ética Profissional \\
\hline
\end{tabular}


Quadro 4 - Lista dos estudos incluídos, São Paulo - 2007. (continuação)

\begin{tabular}{|c|c|c|c|}
\hline Artigo & Objetivo & $\begin{array}{l}\text { Tipo de } \\
\text { estudo }\end{array}$ & Metodologia \\
\hline $\begin{array}{l}\text { Coping with cancer: creative teaching } \\
\text { strategies in an elective for nursing } \\
\text { students } \\
\text { Autor: Clark J } \\
\text { Fonte: ONS Nursing Scan in Oncology }\end{array}$ & $\begin{array}{l}\text { Descrever o processo de ensino aprendizagem na } \\
\text { abordagem de uma experiência na área de } \\
\text { oncologia. }\end{array}$ & Descritivo & $\begin{array}{l}\text { Uso de estratégias de ensino criativas como } \\
\text { dramatizaçăo para explorar os sentimentos dos } \\
\text { alunos em relaçăo ao paciente com câncer. }\end{array}$ \\
\hline $\begin{array}{l}\text { Educational innovations. Reflecting on } \\
\text { service: helping nursing students get the } \\
\text { most from service-learning } \\
\text { Autor: Eyler J }\end{array}$ & $\begin{array}{l}\text { Descrever aspectos que podem nortear a } \\
\text { implementaçãa de atividades que promovam a } \\
\text { reflexão do estudante de enfermagem. }\end{array}$ & Descritivo & $\begin{array}{l}\text { Descrição sobre o processo ensino aprendizagem e } \\
\text { utilizaçấ de estratégias de ensino, como a } \\
\text { dramatização em determinadas situaçoses } \\
\text { estimulando o aspecto reflexivo on estudante sobre } \\
\text { questôes éticas, politicas e de cidadania. }\end{array}$ \\
\hline $\begin{array}{l}\text { Effects of End-of-Life Education on } \\
\text { Baccalaureate Nursing Students } \\
\text { Autor: Thompson GT } \\
\text { Fonte: AORN Journal }\end{array}$ & $\begin{array}{l}\text { Discutir as experiências sobre pacientes em fase } \\
\text { terminal. }\end{array}$ & Descritivo & $\begin{array}{l}\text { Descreve atividades que envolvem o uso da } \\
\text { dramatizacâao, com a gravação das situações } \\
\text { encenadas e análise do video. }\end{array}$ \\
\hline $\begin{array}{l}\text { Effects of using videotaped vignettes on } \\
\text { enhancing students' critical thinking ability } \\
\text { in a baccalaureate nursing programme } \\
\text { Autor: Chau JPC, Chang AM, Lee IFK, } \\
\text { Wootton Y } \\
\text { Fonte: Journal of Advanced Nursing }\end{array}$ & $\begin{array}{l}\text { Determinar os efeitos do uso de vinhetas } \\
\text { gravadas para desenvolver habilidades do } \\
\text { pensamento critico em diferentes situações } \\
\text { clínicas. }\end{array}$ & Descritivo & $\begin{array}{l}\text { Uso da dramatização em grupo de } 83 \text { alunos na } \\
\text { encenaçãa de situaçóes (transporte do paciente do } \\
\text { leito para a cadeira de rodas, punção e medicação } \\
\text { endovenosa, cateterismo gástrico). As situaçães } \\
\text { foram encenadas pelos alunos e gravadas para } \\
\text { projeção e análise posterior. }\end{array}$ \\
\hline $\begin{array}{l}\text { Enabling students to develop confidence } \\
\text { in basic clinical skills } \\
\text { Autor: Mayne W. et al } \\
\text { Fonte: Nurs Times }\end{array}$ & $\begin{array}{l}\text { Desenvolver habilidades e autoconfiança em } \\
\text { situaçôes de prática clínica, através do uso de } \\
\text { técnicas de ensino inovadoras. }\end{array}$ & Descritivo & $\begin{array}{l}\text { Divisão dos alunos em pequenos grupos e } \\
\text { aplicaçãad da dramatizacaão como método de ensino } \\
\text { e aprendizagem com o intuito de trabalhar aspectos } \\
\text { como liderança, comunicação, trabalho em grupo e } \\
\text { autoconfiança. }\end{array}$ \\
\hline $\begin{array}{l}\text { Evaluation of nursing students' work } \\
\text { technique after proficiency training in } \\
\text { patient transfer methods during } \\
\text { undergraduate education } \\
\text { Autor: Johnsson AC, Kjellberg A, } \\
\text { Lagerstrom MI } \\
\text { Fonte: Nurse Education Today }\end{array}$ & $\begin{array}{l}\text { Investigar se os estudantes apresentam melhora } \\
\text { nos trabalhos técnicos por meio de um } \\
\text { treinamento com simulaçōes de pacientes } \\
\text { dependentes para locomoçãao (usando cadeira de } \\
\text { rodas). }\end{array}$ & Quase experimental & 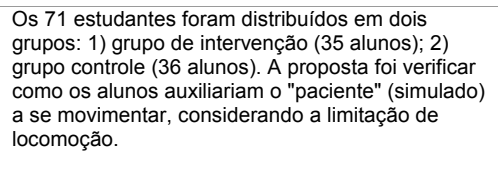 \\
\hline
\end{tabular}
Resultados
Os alunos mostraram-se envolvidos com o processo de ensino astratégias. Houve melhora do
es
conhecimento e mudança nas atitudes
 pensamento crítico, aumentando percepção do aluno sobre a responsabilidade de instituições publicas e entidades governamentals
Om aumento no grauram que houve lidar com paciente em fase terminal. Houve aumento do conhecimento en relaçáa a medicação e tecrnicas de Melhora do conhecimento porém não tei significante o aumento, porem náo habilidades do pensamento critico.
Houve um aumento na competência e técnicas, melhorando as hacóilidas
práticas para o exercício da profissão, observou-se o desenvolvimento do senso de trabalho em grupo e tomada
s resultados mostraram que os
técnica de transferência de pacient
bem como houve um ganho na
percep̧̧ão sobre os aspectos de
conforto e segurança que devem ser
técnica.

\begin{tabular}{|l|}
\hline Área \\
\hline $\begin{array}{l}\text { Enfermagem em } \\
\text { Oncologia }\end{array}$ \\
\hline Não especifica \\
\hline Não especifica \\
\hline Não especifica \\
\hline Não especifica \\
\hline Não especifica \\
\hline
\end{tabular}


Quadro 4 - Lista dos estudos incluídos, São Paulo - 2007. (continuação)

\begin{tabular}{|c|c|c|c|c|c|}
\hline Artigo & Objetivo & $\begin{array}{l}\text { Tipo de } \\
\text { estudo }\end{array}$ & Metodologia & Resultados & Área \\
\hline $\begin{array}{l}\text { Evaluation of students' learning through } \\
\text { simulation experience study in } \\
\text { gerontological nursing education-- } \\
\text { understanding the elderly person and the } \\
\text { role of the caregiverer } \\
\text { Autor: Muroya K. et al } \\
\text { Fonte: Journal of UOEH }\end{array}$ & $\begin{array}{l}\text { Verificar a aprendizagem dos estudantes sobre o } \\
\text { envelhecimento e o cuidador do idoso através de } \\
\text { uma simulação. }\end{array}$ & Exploratório & $\begin{array}{l}\text { Os alunos receberam textos sobre o } \\
\text { envelhecimento humano em várias dimensões } \\
\text { (psicológican, social, fisiológicica, ambiental) e } \\
\text { orientaçōes. A classe foi dividida em dois grupos: } \\
\text { um grupo representou o papel do idoso o o outro } \\
\text { grupo assumiu o papel do cuidador. Um aluno de } \\
\text { cada grupo formou uma dupla (idoso e cuidador) e } \\
\text { realizaram atividades da vida diária. Cabia aos } \\
\text { "alunos cuidadores" manter a comunicação e } \\
\text { acompanhar os "alunos idosos", ajudando-os nas } \\
\text { atividades. }\end{array}$ & $\begin{array}{l}\text { Melhora no conhecimento e } \\
\text { compreensão sobre o envelhecimento, } \\
\text { reconhecendo as necessidades do } \\
\text { próximo e valorizando suas açôs. A } \\
\text { experiência contribuiu na reflexão } \\
\text { sobre a vida cotidiana dos idosos e as } \\
\text { caracteristicas peculiares da } \\
\text { assistencia de enfermagem nesta fase } \\
\text { da vida. }\end{array}$ & Geriatria \\
\hline $\begin{array}{l}\text { Experiential learning in drug and alcohol } \\
\text { education } \\
\text { Autor: Norman } R \\
\text { Fonte: The Journal of Nursing Education }\end{array}$ & $\begin{array}{l}\text { Prover ao aluno conhecimentos relacionados ao } \\
\text { uso abusivo de álcool e drogas. }\end{array}$ & Descritivo & $\begin{array}{l}\text { Em um workshop os alunos simulam personagens } \\
\text { usuários de drogas eáccool, procurando } \\
\text { desenvolver no futuro profissional os } \\
\text { conhecimentos para assistir aos pacientes nessas } \\
\text { situaçóes. }\end{array}$ & $\begin{array}{l}\text { Avaliado de maneira positiva, houve } \\
\text { aumento do conhecimento sobre o } \\
\text { tema, necessidade de cuidado e } \\
\text { respeito com o usuário, sem } \\
\text { discriminação. }\end{array}$ & Não especifica \\
\hline $\begin{array}{l}\text { Family skills labs: facilitating the } \\
\text { development of family nursing skills in the } \\
\text { undergraduate curriculum } \\
\text { Autor: Tapp DM } \\
\text { Fonte: Journal of Family Nursing }\end{array}$ & $\begin{array}{l}\text { Descrever a implementação de um laboratório de } \\
\text { enfermagem voltado à assistência à família. }\end{array}$ & Descritivo & $\begin{array}{l}\text { O laboratório foi desenvolvido a fim de facilitar o } \\
\text { desenvivolvimento das habilidades doe estudante em } \\
\text { relação assistência familiar através de estratégias } \\
\text { de ensino como dramatizaçãoo e simulaçăão de } \\
\text { situaçôos. }\end{array}$ & $\begin{array}{l}\text { Melhora do conhecimento, das } \\
\text { habilidades para prática clinica, } \\
\text { desenvolvimento de mecanismos para } \\
\text { entrevistas familiares, pensamento } \\
\text { crítico. }\end{array}$ & Saúde da Familia \\
\hline $\begin{array}{l}\text { Florence Nightingale: Revolução na arte } \\
\text { do cuidar } \\
\text { Autor: Andrade NC et al } \\
\text { Fonte: } 57^{\circ} \text { Congresso Brasileiro de } \\
\text { Enfermagem - } 03 \text { a } 07 \text { de Novembro de } \\
2005 \text { - Goiânia - Goiás. }\end{array}$ & $\begin{array}{l}\text { Relatar aos alunos e espectadores a } \\
\text { representação da Dama da Lâmpada, o que ela } \\
\text { fez e como foi a sua luta para expandir o exercício } \\
\text { da enfermagem pelo mundo. }\end{array}$ & Descritivo & $\begin{array}{l}\text { O tema foi apresentado à uma turma alunos do } \\
\text { primeiro periodo do curso de enfermagem. Este } \\
\text { estudo foi desenvolvido por meio de pesquisas } \\
\text { bibliográificas, sobre a História da Enfermagem. O } \\
\text { enredo foi elaborado e dramatizado pelos alunos. }\end{array}$ & $\begin{array}{l}\text { O método da dramatização foi bem } \\
\text { aceito e muito elogiado pelos alunos, a } \\
\text { compreensão do assunto tornou-se } \\
\text { mais interessante, proporcionando } \\
\text { uma maior interação entre os alunos. }\end{array}$ & $\begin{array}{l}\text { História da } \\
\text { Enfermagem }\end{array}$ \\
\hline $\begin{array}{l}\text { Fostering holistic care in oncology nursing } \\
\text { Autor: Lohri-Posey BS } \\
\text { Fonte: Nurse Educator }\end{array}$ & $\begin{array}{l}\text { Estimular os estudantes de enfermagem a } \\
\text { compreender as necessidades holisticas de } \\
\text { pacientes com câncer. }\end{array}$ & Descritivo & $\begin{array}{l}\text { Foi proposta a leitura, com antecedência, sobre o } \\
\text { tema Tumor Ossseo e depois, a realizacaão da } \\
\text { dramatizaçăo sobre a condiçâo do portador da } \\
\text { doença. Os alunos entrevistaram pacientes e } \\
\text { usaram a criatividade para compor os personagens } \\
\text { de diferentes faixas etárias. }\end{array}$ & $\begin{array}{l}\text { Os estudantes relataram que a técnica } \\
\text { motivou um contato com pessoas com } \\
\text { câncer para elaborar o personagem, } \\
\text { possibilitou compreender as } \\
\text { necessidades holísticas dessas } \\
\text { pessoas e contribuiu no } \\
\text { desenvolvimento de habilidades } \\
\text { comunicacionais. }\end{array}$ & Oncologia \\
\hline $\begin{array}{l}\text { Holding children for invasive procedures: } \\
\text { preparing student nurses } \\
\text { Autor: Valler-Jones T, Shinnick A } \\
\text { Fonte: Paediatr Nurs }\end{array}$ & $\begin{array}{l}\text { Assegurar o equilibrio entre a teoria e prática, } \\
\text { conscientizando os estudantes sobre as } \\
\text { dificuldades clinicas na validaçâo, eficácia e } \\
\text { aceitabilidade dos procedimentos }\end{array}$ & Exploratório & $\begin{array}{l}\text { Foi proposta a leitura prévia do conteúdo a ser } \\
\text { abordado, seguida da utilização da dramatização } \\
\text { no ensino de procedimentos invasivos na criança } \\
\text { (venopunçãoo, coleta de sangue, administraçãa de } \\
\text { medicação, punç̧ão lombar). }\end{array}$ & $\begin{array}{l}\text { Aumento na confiança, segurança, } \\
\text { conhecimento. }\end{array}$ & Saúde da Criança \\
\hline $\begin{array}{l}\text { How to conduct an assertion training } \\
\text { course for nursing students: a step-by- } \\
\text { step plan for instruction } \\
\text { Autor: Thomas SP } \\
\text { Fonte: Journal of Nursing Education }\end{array}$ & $\begin{array}{l}\text { Assistir os estudantes no processo de } \\
\text { aprendizagem e melhora de habilidades } \\
\text { assertivas para o exercício da profissão. }\end{array}$ & Descritivo & $\begin{array}{l}\text { Durante o desenvolvimento de um curso utilizou-se } \\
\text { a dramatização na etapa inicial a fim de estabelecer } \\
\text { uma atmosfera de confiança entre os elementos do } \\
\text { grupo. }\end{array}$ & $\begin{array}{l}\text { Os esforços empregados neste } \\
\text { processos são evidenciados quando o } \\
\text { estudante relata que se sente melhor } \\
\text { como pessoa e como futuro } \\
\text { profisssional, porter aumentado a } \\
\text { habilidade quanto à assertividade, } \\
\text { auto-estima e autoconfiança. }\end{array}$ & Saúde Mental \\
\hline
\end{tabular}


Quadro 4 - Lista dos estudos incluídos, São Paulo - 2007. (continuação)

\begin{tabular}{|c|c|c|c|c|c|}
\hline Artigo & Objetivo & $\begin{array}{l}\text { Tipo de } \\
\text { estudo }\end{array}$ & Metodologia & Resultados & Área \\
\hline $\begin{array}{l}\text { Innovative teaching of management skills } \\
\text { Autor: Schuldenfrei P, Zafft C } \\
\text { Fonte: Nurse Educator }\end{array}$ & $\begin{array}{l}\text { Utilizar a dramatizacãão para desenvolver } \\
\text { habilidades administrativas dos estudantes de } \\
\text { enfermagem. }\end{array}$ & Exploratório & 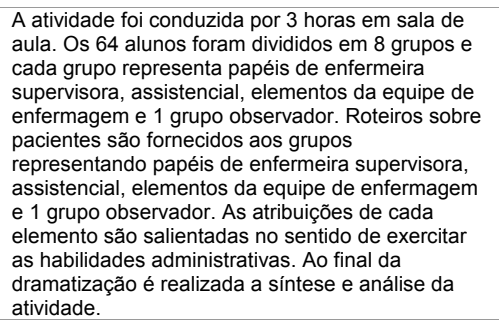 & $\begin{array}{l}\text { O exercício favoreceu a integração } \\
\text { das diversas habilidades no processo, } \\
\text { estimulando a criação de um plano de } \\
\text { ação e soluções criativas. Os } \\
\text { estudantes sentiram-se motivados e } \\
\text { confortáveis neste ambiente seguro } \\
\text { para enfrentar os desafios da } \\
\text { realidade prática. Foi detectado que } \\
\text { os estudantes têm dificuldades em } \\
\text { estabelecer prioridades, apresentam } \\
\text { dificuldades em discernir aspectos } \\
\text { importantes e os superficiais na } \\
\text { questão administrativa. }\end{array}$ & $\begin{array}{l}\text { Administração em } \\
\text { Enfermagem }\end{array}$ \\
\hline $\begin{array}{l}\text { Integrating an exercise on mass casualty } \\
\text { response into the curriculum } \\
\text { Autor: Decker SI, Galvan TJ, Sridaromont } \\
\mathrm{K} \\
\text { Fonte: Journal of Nursing Education }\end{array}$ & $\begin{array}{l}\text { Refletir sobre a necessidade de inclusão } \\
\text { curricular aspectos relevantes na formação do } \\
\text { enfermeiro, relacionado ao atendimento em } \\
\text { emergência nas situaçôes de catástrofes em } \\
\text { massa. }\end{array}$ & Descritivo & $\begin{array}{l}\text { Os alunos foram divididos em grupos dramatizando } \\
\text { situaçōes de emergência, com a criação de } \\
\text { cenarios que retratam desastres em massa. }\end{array}$ & $\begin{array}{l}\text { A simulação de situaçães para } \\
\text { atendimento de emergência propiciou } \\
\text { oportunidades extraordinárias no } \\
\text { aprendizado, o aspecto de aumento } \\
\text { do conhecimento, das habilidades } \\
\text { técnicas, comunicacionais, avaliação } \\
\text { rápida e tomada de decisão. Além ter } \\
\text { sido considerada excitante, os } \\
\text { estudantes identificaram a importância } \\
\text { da comunicação entre diferentes } \\
\text { áreas. }\end{array}$ & Emergência \\
\hline $\begin{array}{l}\text { Learning outcomes in a simulation game } \\
\text { for associate degree nursing students } \\
\text { Autor: Clark C } \\
\text { Fonte: Health Education Monographs }\end{array}$ & $\begin{array}{l}\text { Utilizar os jogos de simulação como estratégia } \\
\text { efetiva de ensino a fim de promover uma } \\
\text { aprendizagem significativa. }\end{array}$ & Exploratório & $\begin{array}{l}\text { A simulação foi dividida em três etapas: orientação, } \\
\text { desenvolvimento e avaliação. Na primeira etapa é } \\
\text { realizada a orientação das regras; na segunda, um } \\
\text { aluno simula o papel de professor ao ensinar sobre } \\
\text { o uso do manual de instrução programada } \\
\text { relacionado à interação enfermeiro-paciente e o } \\
\text { outro aluno simula o papel de enfermeiro; na } \\
\text { terceira etapa é realizada a avaliação. }\end{array}$ & $\begin{array}{l}\text { Esta estratégia de ensino mostrou-se } \\
\text { efetiva, podendo ser aplicada em } \\
\text { qualquer etapa do processo de ensino } \\
\text { aprendizagem. Os jogos mostraram- } \\
\text { se uma alternativa como instrumento } \\
\text { de avaliação em substituição aos } \\
\text { testes convencionais. }\end{array}$ & Saúde Mental \\
\hline $\begin{array}{l}\text { New educational subject in Lorenskog: } \\
\text { patient in practice } \\
\text { Autor: Jarto } G \\
\text { Fonte: Sykepleien }\end{array}$ & $\begin{array}{l}\text { Estabelecer um confrontamento com a futura } \\
\text { profissão e vivenciar o dia-a-dia num posto de } \\
\text { saúde, assumindo o papel de pacientes e } \\
\text { enfermeiros. }\end{array}$ & Exploratório & $\begin{array}{l}\text { Os alunos no primeiro semestre transformaram um } \\
\text { posto de saúde fechado num hospital como local } \\
\text { de treinamento prático e por meio da dramatização, } \\
\text { assumiram papéis de pacientes e profissionais. }\end{array}$ & $\begin{array}{l}\text { Superando as expectativas houve } \\
\text { melhora do conhecimento, onde a } \\
\text { vivência na prática tornou a proposta } \\
\text { mais interessante, envolvente com a } \\
\text { participação ativa dos alunos; relatos } \\
\text { de maior preparo para a etapa prática } \\
\text { do curso (estágios), melhora do } \\
\text { relacionamento interpessoal entre } \\
\text { alunos e professores, aumento da } \\
\text { percepção das limitaçôs dos } \\
\text { pacientes, da importância do preparo } \\
\text { do enfermeiro, da ética profissional, do } \\
\text { pensamento crítico. }\end{array}$ & Não especifica \\
\hline
\end{tabular}


Quadro 4 - Lista dos estudos incluídos, São Paulo - 2007. (continuação)

\begin{tabular}{|c|c|c|c|c|c|}
\hline Artigo & Objetivo & $\begin{array}{l}\text { Tipo de } \\
\text { estudo }\end{array}$ & Metodologia & Resultados & Área \\
\hline $\begin{array}{l}\text { O desafio da utilizacääo de técnicas } \\
\text { pedagógicas inovadoras no ensino da } \\
\text { administraçäo em enfermagem } \\
\text { Autor: Takahashit RT, Peres HHC } \\
\text { Fonte: Rev Paulista de Enfermagem }\end{array}$ & $\begin{array}{l}\text { Desenvolver e aplicar a técnica inovadora com } \\
\text { recursos da dramatizaçãon no ensino das teorias } \\
\text { de Addinistração em Enfermagem. Analisar a } \\
\text { opiniãa dos alunos sobre a aplicą̧ẫo da técnica } \\
\text { da dramatização. }\end{array}$ & Exploratório & 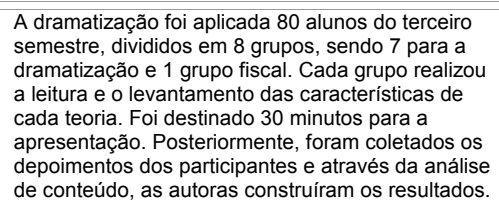 & $\begin{array}{l}\text { A estratágia favoreceu o dinamismo } \\
\text { das aulas, motivando a participacacão } \\
\text { dos alunos, proporcionando aumento } \\
\text { no conhecimento e desenviolvimento } \\
\text { do pensamento crítico. A interação } \\
\text { entre os educandos propiciou o } \\
\text { aspecto reflexivo e integrador no } \\
\text { processo ensino aprendizagem. }\end{array}$ & $\begin{array}{l}\text { Administração em } \\
\text { Enfermagem }\end{array}$ \\
\hline $\begin{array}{l}\text { O psicodrama como uma estratégia } \\
\text { pedagógica no ensino de saúde do } \\
\text { trabalhador } \\
\text { Autor: Martins JT, Opitz SP, Robazzi } \\
\text { MLCC } \\
\text { Fonte: Rev Gaúcha de Enfermagem }\end{array}$ & $\begin{array}{l}\text { Relatar a experiência da utilização do psicodrama } \\
\text { pedagógico como estratégia de ensino I } \\
\text { aprendizagem sobre a Saúde do Trabalhador. }\end{array}$ & Descritivo & $\begin{array}{l}\text { Utilizando o referencial de Moreno, o } \\
\text { desenvolvimento da temática aconteceu em } 3 \\
\text { etapass inicicios-se com o aquecimento, seguida da } \\
\text { encenação de uma familia e suas dificuldades, } \\
\text { enfatizando o papel da mulher nesse núcleo } \\
\text { familiar. Finalizando, a discussão e reflexão da } \\
\text { atividade. }\end{array}$ & $\begin{array}{l}\text { Foi relatado que no início houve } \\
\text { dificuldade em trabalhar nos } \\
\text { subgrupos, devido à ansiedade em } \\
\text { verbalizar e falta de paciência em } \\
\text { ouvir o outro, aspecto que foi resolvido } \\
\text { após a organização das atividades. Os } \\
\text { alunos salientaram a importância da } \\
\text { participação ativa durante o processo, } \\
\text { considerando os conhecimentos } \\
\text { prévios de cada um, tornando a } \\
\text { aprendizagem significativa e } \\
\text { motivadora. A técnica do psicodrama } \\
\text { foi interessante e importante para a } \\
\text { superaçãoo do medo da exposição } \\
\text { frente aos outros colegas. }\end{array}$ & Saúde do Trabalhador \\
\hline $\begin{array}{l}\text { O psicodrama em sala de aula: uma } \\
\text { estratégia de ensino para o } \\
\text { desenvolvimento do papel profissional da } \\
\text { enfermeira } \\
\text { Autor: Kirschbaum DIR; Nozawa MR } \\
\text { Fonte: Rev Brasileira de Enfermagem }\end{array}$ & $\begin{array}{l}\text { Propiciar ao aluno a obtenção de um estado de } \\
\text { espontaneidade que Ihe possibilite desempenhar } \\
\text { adequadamente seus papéis sociais de aluno e } \\
\text { de enfermeiro, utilizando o psicodrama como } \\
\text { estratégia pedagógica. }\end{array}$ & Descritivo & 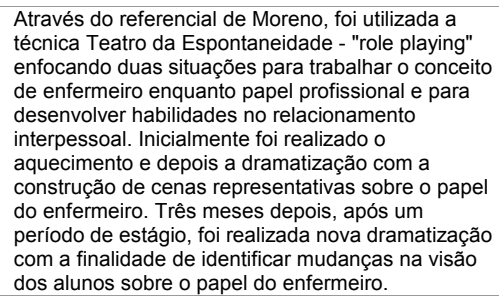 & $\begin{array}{l}\text { A técnica possibilitou ao estudante } \\
\text { desenvolver papéis sociais e relações } \\
\text { interpessoais num ambiente relaxado } \\
\text { e protegido, experimentando } \\
\text { diferentes graus de espontaneidade, } \\
\text { vivenciando o processo de tomada e } \\
\text { compreendendo melhor o papel } \\
\text { profissional do enfermeiro. }\end{array}$ & $\begin{array}{l}\text { Introdução à } \\
\text { Enfermagem }\end{array}$ \\
\hline $\begin{array}{l}\text { Patient care simulations: role playing to } \\
\text { enhance clinical understanding } \\
\text { Autor: Comer SK } \\
\text { Fonte: Nurs Educ Perspect }\end{array}$ & $\begin{array}{l}\text { Aumentar as habilidades do aluno utilizando a } \\
\text { dramatização em simulação de hipóxia no } \\
\text { paciente. }\end{array}$ & Descritivo & $\begin{array}{l}\text { Realizada uma seleção aleatória de alguns alunos } \\
\text { para ser o paciente, enfermeira e médico, } \\
\text { dramatizando situação de insuficiência respiratória, } \\
\text { relacionando as açôes para os cuidados de } \\
\text { enfermagem. }\end{array}$ & $\begin{array}{l}\text { Houve melhora das habilidades } \\
\text { clinicas com feedback positivo. Alguns } \\
\text { alunos mostraram frustracăo, } \\
\text { alegando o tempo curto para realizar a } \\
\text { atividaded. Apenas um aluno } \\
\text { manifestou que se sentia } \\
\text { despreparado para assistir o paciente. }\end{array}$ & Terapia Intensiva \\
\hline $\begin{array}{l}\text { Perceived and actual decision making by } \\
\text { novice baccalaureate students } \\
\text { Autor: Thiele JE, Holloway J, Murphy D, } \\
\text { Pendarvis J, Stucky M } \\
\text { Fonte: West J Nurs Res }\end{array}$ & $\begin{array}{l}\text { Determinar os padrões e percepções na tomada } \\
\text { de decisão clínica dos estudantes em início de } \\
\text { curso de enfermagem. }\end{array}$ & Descritivo & $\begin{array}{l}\text { A amostra de conveniência composta por } 82 \\
\text { estudantes. Foi desenvolvida uma situação peri- } \\
\text { operatória envolvendo um paciente com câncer } \\
\text { retal para simulacaâao, estimulação e investigação na } \\
\text { tomada de decisâa. }\end{array}$ & $\begin{array}{l}\text { Os estudantes avaliaram a simulação } \\
\text { de forma positiva ao promover o } \\
\text { aprendizado e aplicação prática, por } \\
\text { se tratar de um ambiente seguro na } \\
\text { tomada de decisão. }\end{array}$ & Não especifica \\
\hline
\end{tabular}


Quadro 4 - Lista dos estudos incluídos, São Paulo - 2007. (continuação)

\begin{tabular}{|c|c|c|c|c|c|}
\hline Artigo & Objetivo & $\begin{array}{l}\text { Tipo de } \\
\text { estudo }\end{array}$ & Metodologia & Resultados & Área \\
\hline $\begin{array}{l}\text { Planning for a new baby: a creative } \\
\text { approach to learning } \\
\text { Côté-Arsenault } D \\
\text { Fonte: Nurse Educator }\end{array}$ & $\begin{array}{l}\text { Desenvolver um projeto de aprendizagem ativa } \\
\text { relacionado ao processo de gestação e } \\
\text { maternidade. }\end{array}$ & Exploratório & 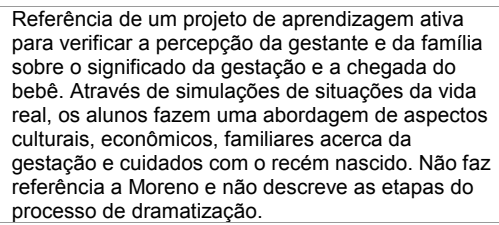 & $\begin{array}{l}\text { Melhora da percepção do estudante } \\
\text { em relação à condiçãoo da gestante, } \\
\text { dos valores culturais que interferem na } \\
\text { aceitação desta nova condição. }\end{array}$ & Saúde da Mulher \\
\hline $\begin{array}{l}\text { Potential for violence toward psychiatric } \\
\text { nursing students: risk reduction } \\
\text { techniques } \\
\text { Autor: Echternacht MR } \\
\text { Fonte: Journal of Psychosocial Nursing \& } \\
\text { Mental Health Services }\end{array}$ & $\begin{array}{l}\text { Verificar se os estudantes de enfermagem podem } \\
\text { tornar-se potenciais alvos de violência. }\end{array}$ & Descritivo & $\begin{array}{l}\text { Uso de técnicas de dramatização, comunicação } \\
\text { verbal e não verbal, a fim de preparar os } \\
\text { estudantes para situaçōes clinicas em enfermagem } \\
\text { psiquiátrica. }\end{array}$ & $\begin{array}{l}\text { Embora a violênncia esteja } \\
\text { frequentemente associada com } \\
\text { fatores psiquiatricos facilitadores, é } \\
\text { fato que a violência não se limita } \\
\text { somente nesta área da enfermagem, } \\
\text { daí a necessidade de preparar os } \\
\text { estudantes, para que não se tornem } \\
\text { alvos fáceis. }\end{array}$ & Saúde Mental \\
\hline $\begin{array}{l}\text { Preparing Psychiatric Mental Health } \\
\text { Nurses for the Future: A Baccalaureate } \\
\text { Curriculum Design } \\
\text { Autor: Esparza DV et al } \\
\text { Fonte: Nurse Educator }\end{array}$ & $\begin{array}{l}\text { Criar e implementar um curriculum inovador na } \\
\text { área de Saude Mental. }\end{array}$ & Descritivo & $\begin{array}{l}\text { Os autores enfatizam a importância do bom } \\
\text { preparo dos enfermeiros ao assistir o paciente } \\
\text { psiquiátrico. Este preparo iniciai-se na escola e os } \\
\text { autores defendem a mudança no desenho } \\
\text { curricular em Saúde Mental a fim de preparar } \\
\text { melhor os alunos, através da utilização de } \\
\text { estratégias como a dramatização para estimular } \\
\text { habilidades e comunicaçãa terapêutica. }\end{array}$ & $\begin{array}{l}\text { Relataram que a experiência foi } \\
\text { proveitosa, positiva quanto ao } \\
\text { aprendizado. }\end{array}$ & Saúde Mental \\
\hline $\begin{array}{l}\text { Psicodrama como estratégia pedagógica: } \\
\text { vivências no ensino de graduação na área } \\
\text { de saúde da mulher } \\
\text { Autor: Diniz NMF, Lopes R M, Almeida } \\
\text { MS, Gesteira SMA, Oliveira JF } \\
\text { Fonte: Rev Latino-Americana de } \\
\text { Enfermagem }\end{array}$ & $\begin{array}{l}\text { Divulgar a experiência docente de apropriação do } \\
\text { psicodrama como estratégia pedagógica no } \\
\text { desenvolvimento de questôes relativas à saúde } \\
\text { da mulher. }\end{array}$ & Exploratório & $\begin{array}{l}\text { Foi utilizado o método educacional psicodramático } \\
\text { proposto por Romana, enfatizando o estudo das } \\
\text { relacocoes de genero. Inicioulse com o aquecimento, } \\
\text { seguida da encenação de uma familia e suas } \\
\text { dificuldades, enfatizando o papel da mulher nesse } \\
\text { núcleo familiar; finalizando com a discussão es } \\
\text { reflexão da atividade. }\end{array}$ & 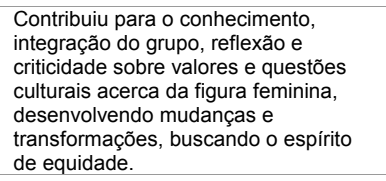 & Saúde da Mulher \\
\hline $\begin{array}{l}\text { Reducing the threat: an experimental } \\
\text { exercise to introduce role play to student } \\
\text { nurses } \\
\text { Autor: Pulsford D } \\
\text { Fonte: Nurse Education Today }\end{array}$ & $\begin{array}{l}\text { Encorajar os estudantes a discutir temas } \\
\text { relacionados à dramatização e tomar decisões } \\
\text { quanto à participaçôoes futuras nessas dinâmicas. }\end{array}$ & Descritivo & $\begin{array}{l}\text { O autor faz uma descrição sobre a dramatização } \\
\text { como estratégia, descrevendo conceitos, } \\
\text { aplicabilidade, efeitos, vantagens e desvantagens, } \\
\text { papel do aplicador, etapas do processo e } \\
\text { resultados. }\end{array}$ & $\begin{array}{l}\text { O autor considera que este método } \\
\text { tem grande significado pelo exercício } \\
\text { e estimulo que provoca, ainda que } \\
\text { não fique claro sobre as mudanças de } \\
\text { atitudes conseqüentes à participação } \\
\text { na dramatizaçăo. }\end{array}$ & Educação \\
\hline $\begin{array}{l}\text { Reflecting on Service: Helping Nursing } \\
\text { Students Get the Most From Service- } \\
\text { Learning } \\
\text { Autor: Eyler J } \\
\text { Fonte: Journal of Nursing Education }\end{array}$ & $\begin{array}{l}\text { Descrever um esquema que pode ser usado } \\
\text { como guia na construção de atividades reflexivas } \\
\text { sobre a relaçăo entre as áreas ensino e } \\
\text { assistência. }\end{array}$ & Descritivo & $\begin{array}{l}\text { São utilizadas estratégias como dramatização e } \\
\text { apresentaçôs sobre situações relacionadas ao } \\
\text { ensino e assistência. }\end{array}$ & $\begin{array}{l}\text { Aumento da capacidade de reflexão, } \\
\text { envolvendo a relação de ensino e } \\
\text { assistência nos diferentes niveis de } \\
\text { atuaçẫo. }\end{array}$ & Não especifica \\
\hline $\begin{array}{l}\text { Representaçöes do aluno de graduaçäo } \\
\text { em enfermagem acerca da prática/papel } \\
\text { do enfermeiro: um relato de experiência } \\
\text { Autor: Aguiar MGG, Boery RNSO } \\
\text { Fonte: Rev Brasileira de Enfermagem }\end{array}$ & $\begin{array}{l}\text { Conhecer a percepção do aluno de uma forma } \\
\text { dinâmica e atraente, sobre a enfermagem como } \\
\text { profissão; realizar atividades em conjunto, visan- } \\
\text { do a aintegracăão dos grupos de estágios; estimular } \\
\text { a criatividade como forma de expressão da sua } \\
\text { visão da profissão e do profissional enfermeiro. }\end{array}$ & Descritivo & 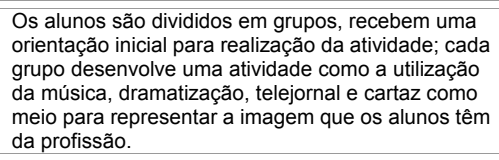 & $\begin{array}{l}\text { Houve o estímulo à reflexão, } \\
\text { desenvolvimento do senso critico } \\
\text { sobre o posicionamento da } \\
\text { enfermagem visando à transformação } \\
\text { das condições de trabalho, através da } \\
\text { reflexão tomada de consciência. }\end{array}$ & $\begin{array}{l}\text { Introdução à } \\
\text { Enfermagem }\end{array}$ \\
\hline
\end{tabular}


Quadro 4 - Lista dos estudos incluídos, São Paulo - 2007. (continuação)

\begin{tabular}{|c|c|c|c|c|c|}
\hline Artigo & Objetivo & $\begin{array}{l}\text { Tipo de } \\
\text { estudo }\end{array}$ & Metodologia & Resultados & Área \\
\hline $\begin{array}{l}\text { Role Play. Two. Planning and preparing } \\
\text { Autor: Tomlinson A, Clarh MJ, Faulkner } \\
\text { Fonte: Nurs Times }\end{array}$ & $\begin{array}{l}\text { Descrever como planejar, preparar e conduzir } \\
\text { uma sessão de dramatização. }\end{array}$ & Descritivo & 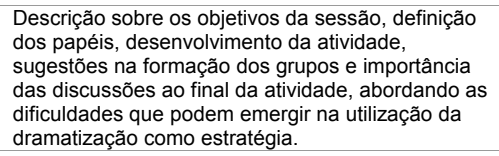 & $\begin{array}{l}\text { Relaciona ser uma experiência } \\
\text { positiva, enfatizando a melhora da } \\
\text { aprendizagem, das habilidades } \\
\text { comunicacionais e de relacionamento } \\
\text { interpessoal. }\end{array}$ & Não especifica \\
\hline $\begin{array}{l}\text { ROPES: An Experiential Learning Activity } \\
\text { For Leadership Skills } \\
\text { Autor: Kirkpatrick MK, Brown S, Koldjeski } \\
\text { D } \\
\text { Fonte: Nurse Educator }\end{array}$ & $\begin{array}{l}\text { Familiarizar os enfermeiros educadores com a } \\
\text { atividade ROPES que pode ser inserida nas aulas } \\
\text { a ifm de contribuir no ensino de conceitos e } \\
\text { habilidades. }\end{array}$ & Descritivo & $\begin{array}{l}\text { E descrita uma série de exercícios que pode ser } \\
\text { utilizada com estratégia de ensino como a } \\
\text { dramatizaçâo. }\end{array}$ & $\begin{array}{l}\text { Os estudantes referem que esta } \\
\text { atividade proporciona experiências, } \\
\text { estimula o trabalho em grupo, o } \\
\text { pensamento critico e o } \\
\text { desenvolvimento de habilidades. }\end{array}$ & Não especifica \\
\hline $\begin{array}{l}\text { Seeing is believing } \\
\text { Autor: Malo-Juvera D } \\
\text { Fonte: Nurs Outlook }\end{array}$ & $\begin{array}{l}\text { Despertar a preocupação do professor quanto á } \\
\text { necessidade da conscientização dos estudantes } \\
\text { quanto às próprias atitudes. }\end{array}$ & Exploratório & $\begin{array}{l}\text { Através da dramatização de situaç̧̃es envolvendo } \\
\text { temas como alimentação da criança, treinamento } \\
\text { da criança quanto às eliminaçôes e retirada da } \\
\text { fraldaa, educação sexual, os estudantes criam } \\
\text { cenários, representam os papéis, externando suas } \\
\text { crenças, caracteristicas e maneiras de abordar os } \\
\text { familiares. }\end{array}$ & $\begin{array}{l}\text { Este tipo de prática permititiu que os } \\
\text { estudantes tomassem consciência de } \\
\text { seus sentimentos, atitudes que } \\
\text { refletiam a proporia educacaáo familiar e } \\
\text { mostraram-se mais sensiveis às } \\
\text { experiências dos colegas. }\end{array}$ & Não especifica \\
\hline $\begin{array}{l}\text { Simulação no ensino do sistema } \\
\text { cardiorrespiratório: relato de uma } \\
\text { experiência inovadora } \\
\text { Autor: Schmidt EA, Carvalho ABB, Tani } \\
\text { EM, Alves I } \\
\text { Fonte: Rev Paulista de Enfermagem }\end{array}$ & $\begin{array}{l}\text { Criar um clima de receptividade na classe, } \\
\text { identificar as principais estruturas anatômicas do } \\
\text { sistema cardiorrespiratório e compreender seu } \\
\text { funcionamento. }\end{array}$ & Descritivo & 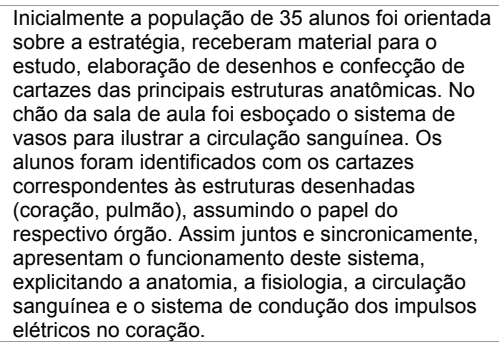 & $\begin{array}{l}\text { Os alunos tiveram uma melhora no } \\
\text { conhecimento, aplicaram estes } \\
\text { conhecimentos em campo de estágio, } \\
\text { e relacionaram conteúdos de outras } \\
\text { disciplinas, manifestando uma } \\
\text { aprendizagem facilitada. }\end{array}$ & $\begin{array}{l}\text { Anatomia e Fisiologia } \\
\text { do Sistema } \\
\text { Cardiocirculatório }\end{array}$ \\
\hline $\begin{array}{l}\text { Student nurses' use of their interpersonal } \\
\text { skills within clinical role-plays } \\
\text { Autor: Ashmore R, Banks D } \\
\text { Fonte: Nurse Education Today }\end{array}$ & $\begin{array}{l}\text { Analisar as habilidades dos estudantes de } \\
\text { enfermagem baseado no sistema de Heron. }\end{array}$ & Exploratório & $\begin{array}{l}\text { O estudo envolveu uma amostra de conveniência } \\
\text { composta por } 46 \text { estudantes de enfermagem, } \\
\text { utilizando a dramatização para estimular a } \\
\text { habilidade de comunicação e relacionamento } \\
\text { interpessoal. }\end{array}$ & $\begin{array}{l}\text { A dramatização contribuiu no } \\
\text { desenvolvimento das habilidades } \\
\text { apesar da limitação do estudo quanto } \\
\text { ao tipo de amostra. }\end{array}$ & Não especifica \\
\hline $\begin{array}{l}\text { Teaching communication skills: effects of } \\
\text { two methods of instruction and selected } \\
\text { learner characteristics } \\
\text { Autor: Norris J } \\
\text { Fonte: Journal of Nursing Education }\end{array}$ & $\begin{array}{l}\text { Comparar a aquisição de habilidades } \\
\text { comunicacionais através da utilização da } \\
\text { dramatização como método de ensino não } \\
\text { tradicional e eitura orientada como método de } \\
\text { ensino tradicional }\end{array}$ & Comparativo & 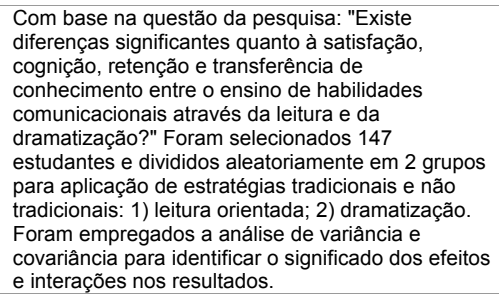 & $\begin{array}{l}\text { O grupo } 1 \text { (leitura) indicou grande } \\
\text { confiança no método, por ser objetivo } \\
\text { e compreensivel. Oo grupo } 2 \text { ond } \\
\text { (dramatizaçâa) indicou grande } \\
\text { interesse, envolvimento ativo e } \\
\text { preferência pelo método. }\end{array}$ & Não especifica \\
\hline
\end{tabular}


Quadro 4 - Lista dos estudos incluídos, São Paulo - 2007. (continuação)

\begin{tabular}{|c|c|c|c|c|c|}
\hline Artigo & Objetivo & $\begin{array}{l}\text { Tipo de } \\
\text { estudo }\end{array}$ & Metodologia & Resultados & Área \\
\hline $\begin{array}{l}\text { Teaching Nursing Students to Promote } \\
\text { the Health of Communities: A Partnership } \\
\text { Approach } \\
\text { Autor: : Falk-Rafael A, Ward-Griffin C, } \\
\text { Laforet-Fliesser Y, Beynon C } \\
\text { Fonte: Nurse Educator }\end{array}$ & $\begin{array}{l}\text { Descrever um modelo de ensino para promover a } \\
\text { saúde da comunidade. }\end{array}$ & Descritivo & $\begin{array}{l}\text { Durante a realização de um curso na área de } \\
\text { Saúde Coletiva, procurou-se integrar os alunos } \\
\text { junto à comunidade. Foram utilizadas estratégias } \\
\text { como a dramatização e simulação, com o intuito de } \\
\text { simular situações em que o aluno pudesse } \\
\text { identififarar as potencialidades dos representantes } \\
\text { da comunidade. }\end{array}$ & $\begin{array}{l}\text { Os estudantes sentiram-se motivados } \\
\text { ao trabalhar em parceria com a } \\
\text { comunidade, passaram a valorizar a } \\
\text { atenção primária na saúde, bem como } \\
\text { o aspecto inter-relacional foi } \\
\text { estimulado, atraves do trabalho } \\
\text { cooperativo. }\end{array}$ & Saúde Coletiva \\
\hline $\begin{array}{l}\text { Testing Theory Through Theatrics } \\
\text { Autor: Sellers SC } \\
\text { Fonte: Journal of Nursing Education }\end{array}$ & $\begin{array}{l}\text { Promover o ensino das teorias de enfermagem } \\
\text { utilizando a dramatização como estratégia de } \\
\text { ensino. }\end{array}$ & Exploratório & $\begin{array}{l}\text { Foram selecionados } 13 \text { a } 15 \text { estudantes de } \\
\text { enfermagem durante a abordagem das teorias de } \\
\text { enfermagem. Etrtatégias foram aplicadada a cada } \\
\text { grupo (entrevistas, quebra cabeça, jogos, videos) } \\
\text { incluindo o uso da dramatizacaâo para verificar a } \\
\text { aprendizagem sobre das diferentes teorias. }\end{array}$ & $\begin{array}{l}\text { Melhora do conhecimento sobre o } \\
\text { tema abordado (Teorias de } \\
\text { Enfermagem), criatividade, } \\
\text { pensamento critico. }\end{array}$ & Não especifica \\
\hline $\begin{array}{l}\text { The Benefits of Serving on a Hospital } \\
\text { Ethics Committee: A Faculty Perspective } \\
\text { Autor: Robley LR } \\
\text { Fonte: Nurse Educator }\end{array}$ & $\begin{array}{l}\text { Discutir a relação entre um sistema hospitalar da } \\
\text { periferia e um hospitalar universitário quanto à } \\
\text { questâo ética. }\end{array}$ & Descritivo & $\begin{array}{l}\text { Este estudo faz uma abordagem reflexiva sobre } \\
\text { questōoss éticas nos diferentes serviços e relaciona } \\
\text { o uso da dramatização para criar situaçōes onde os } \\
\text { alunos possam discutir o tema. }\end{array}$ & $\begin{array}{l}\text { A relação ética entre profissionais, } \\
\text { pacientes deve ser assunto a ser } \\
\text { tratado no curso de enfermagem, bem } \\
\text { como a importância dos comitês de } \\
\text { ética, de maneira envolvente, } \\
\text { estimulando o interesse do aluno e } \\
\text { principalmente, formar um profissional } \\
\text { ético. }\end{array}$ & Ética Profissional \\
\hline $\begin{array}{l}\text { The effect of classroom simulation on } \\
\text { nursing students' self-efficacy related to } \\
\text { health teaching } \\
\text { Autor: Goldenberg D, Andrusyszyn MA, } \\
\text { Iwasiw C } \\
\text { Fonte: Journal of Nursing Education }\end{array}$ & $\begin{array}{l}\text { Investigar o efeito da simulação como auto- } \\
\text { eficiência no ensino em saúde. }\end{array}$ & Exploratório & $\begin{array}{l}\text { O estudo envolveu uma amostra de conveniência } \\
\text { composta por } 22 \text { estudantes de enfermagem que } \\
\text { participaram de sessões de simulação sobre } \\
\text { ensino em sádede, por ser este um tema básico na } \\
\text { prática de enfermagem. }\end{array}$ & $\begin{array}{l}\text { Os estudantes tiveram uma } \\
\text { participação ativa através da } \\
\text { dramatização, utilizada como } \\
\text { estratégia para estimular a } \\
\text { autoconfiança. Houve melhora no } \\
\text { conhecimento sobre o processo } \\
\text { ensino aprendizagem, possibilitando a } \\
\text { troca de experiências. } \\
\text { Limitação do estudo: amostra de } \\
\text { conveniência, não aleatória. }\end{array}$ & Não especifica \\
\hline $\begin{array}{l}\text { The use of humor and role-playing in } \\
\text { reinforcing key concepts } \\
\text { Autor: Lee CJ, Lamp JK } \\
\text { Fonte: Nurse Educator }\end{array}$ & $\begin{array}{l}\text { Relacionar o uso do humor na sala de aula e a } \\
\text { aprendizagem utilizando a dramatização. }\end{array}$ & Descritivo & $\begin{array}{l}\text { Reflexão sobre o uso de estratégias motivadoras } \\
\text { como a dramatizacăão através da vivência de uma } \\
\text { situação de gravidez e suas implicaçôes. }\end{array}$ & $\begin{array}{l}\text { Resultados positivos, pela criação de } \\
\text { um ambiente descontraído e e } \\
\text { favorecimento da aprendizagem. }\end{array}$ & Saúde da Mulher \\
\hline $\begin{array}{l}\text { To be touched by AIDS: an HIV- } \\
\text { experiential teaching method } \\
\text { Autor: Cornelius JB } \\
\text { Fonte: Journal of Nursing Education }\end{array}$ & Aumentar o conhecimento sobre HIV. & Descritivo & $\begin{array}{l}\text { Consiste na aplicação de um método de ensino, } \\
\text { cujo conteúdo, didaticamente elaborado, envolve } \\
\text { estratégias como estudo de caso e dramatização } \\
\text { relacionadas ao tema AIDS. }\end{array}$ & $\begin{array}{l}\text { O uso da dramatização promoveu a } \\
\text { melhora do conhecimento, mais } \\
\text { sensibilizacãao (menos discriminação) } \\
\text { sobre a questão, os alunos sentiram- } \\
\text { se estimulados em cuidar dos } \\
\text { portadores do HIV. }\end{array}$ & $\begin{array}{l}\text { Enfermagem em } \\
\text { Clínica Médica }\end{array}$ \\
\hline
\end{tabular}


Quadro 4 - Lista dos estudos incluídos, São Paulo - 2007. (continuação)

\begin{tabular}{|c|c|c|c|c|c|}
\hline Artigo & Objetivo & $\begin{array}{l}\text { Tipo de } \\
\text { estudo }\end{array}$ & Metodologia & Resultados & Área \\
\hline $\begin{array}{l}\text { Try a mock trial } \\
\text { Autor: Haidinyak G } \\
\text { Fonte: Nurse Educator }\end{array}$ & $\begin{array}{l}\text { Ensinar os estudantes de enfermagem sobre os } \\
\text { erros na assistência através da simulação de um } \\
\text { processo juridico e julgamento. }\end{array}$ & Descritivo & 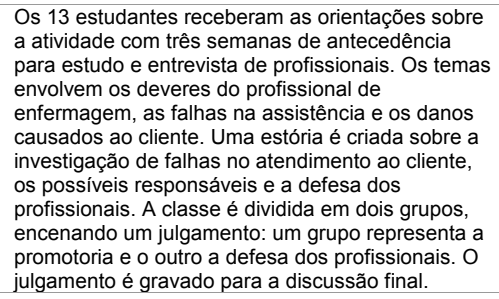 & $\begin{array}{l}\text { Esta atividade, com a participação } \\
\text { ativa dos estudantes, mostrou-se } \\
\text { eficaz na compreensão da importância } \\
\text { de conhecer os direitos e deveres do } \\
\text { profissional de enfermagem e da } \\
\text { documentação das ocorrências. } \\
\text { Proporcionou uma reflexão sobre a } \\
\text { responsabilidade do enfermeiro e o } \\
\text { relacionamento interpessoal, com } \\
\text { ênfase no desenvolvimento de } \\
\text { habilidades comunicacionais. }\end{array}$ & Não especifica \\
\hline $\begin{array}{l}\text { Uma experiência de dramatizaçäo com } \\
\text { alunos de enfermagem } \\
\text { Autor: Goulart SF } \\
\text { Fonte: Dissertação Mestrado (UFRJ) }\end{array}$ & $\begin{array}{l}\text { Identificar as dificuldades do aluno no início do } \\
\text { curso; utilizar a dramatização como contribuição } \\
\text { no relacionamento interpessoal e perspectivas } \\
\text { profissionais. }\end{array}$ & Experimental & $\begin{array}{l}\text { Os } 23 \text { alunos foram divididios em grupo controle e } \\
\text { experimental. A cada encontro semanal (total de } \\
\text { nove encontros) os participantes dramatizavam } \\
\text { estórias que refletiam questōes relacionadas às } \\
\text { próprias dúvidas e dificuldades (perspectiva } \\
\text { profissional, relacionamento interpessoal). Ao } \\
\text { término de cada dramatização, emergiam as } \\
\text { colocacaçōes dos estudantes e do professor. }\end{array}$ & $\begin{array}{l}\text { Os estudantes que participaram do } \\
\text { grupo experimental mostraram-se } \\
\text { favoráveis a esta vivência, sugerindo } \\
\text { que fosse aplicada a todos os alunos } \\
\text { da classe; houve melhora do } \\
\text { relacionamento interpessoal, porém } \\
\text { não contribuiu para melhorar a } \\
\text { perspectiva profissional do aluno. }\end{array}$ & Não especifica \\
\hline $\begin{array}{l}\text { Understanding Abuse and Violence } \\
\text { Against Women: A Two-Day Immersion } \\
\text { Course } \\
\text { Autor: Belknap RA } \\
\text { Fonte: Nurse Educator }\end{array}$ & $\begin{array}{l}\text { Descrever a experiência num curso de imersão } \\
\text { voltado ao abuso da mulher e violência familiar. }\end{array}$ & Relato de caso & $\begin{array}{l}\text { O tema foi apresentado através de leitura de } \\
\text { textos, filmes e dramatização de situações } \\
\text { relacionadas ao tema do curso. }\end{array}$ & $\begin{array}{l}\text { Os alunos ficaram chocados com a alta } \\
\text { incidência da violência contra a mulher e } \\
\text { por ocorrer no ambientef familiar. Após o } \\
\text { curso, sentiram-se mais preparados } \\
\text { para lidar com essas situaçóns, } \\
\text { relacionaram a importância deste } \\
\text { assunto e sua inclusão curricular. }\end{array}$ & Saúde da Mulher \\
\hline $\begin{array}{l}\text { Use of the role-play method in nursing } \\
\text { education } \\
\text { Autor: Schmider } \mathrm{H} \\
\text { Fonte: Deutsche Krankenpflegezeitschrift }\end{array}$ & $\begin{array}{l}\text { Refletir sobre o papel do enfermeiro e considerar } \\
\text { a utilização da dramatização como estratégia no } \\
\text { ensino dos futuros profissionais. }\end{array}$ & Descritivo & $\begin{array}{l}\text { Através de uma abordagem reflexiva, é discutido o } \\
\text { papel do enfermeiro, a formaçãa profissional e o } \\
\text { uso de estratégias de ensino inovadoras como a } \\
\text { dramatizacaáo para a aquisicááo de conhecimento e } \\
\text { o desenvolvimento de habilidades. }\end{array}$ & $\begin{array}{l}\text { A dramatização é um efetivo método } \\
\text { de ensino eaprendizado para as aulas } \\
\text { de enfermagem; estimula cooperação, } \\
\text { tolerância, confiança, sensibilizacacāo } \\
\text { para as necessidades globais dos } \\
\text { pacientes, ao aproximar a teoria e } \\
\text { prática. Entretanto, é necessário que } \\
\text { os professores de enfermagem } \\
\text { reconheçam e entendam essas } \\
\text { vantagens para que decidam se abrir } \\
\text { e aplicar esse método; pela alta } \\
\text { relevância da prática e fidelidade com } \\
\text { situaçóes reais, se distancia de todos } \\
\text { os outros métodos de aprendizagem. }\end{array}$ & Não especifica \\
\hline $\begin{array}{l}\text { Using Critical Thinking Vignettes To } \\
\text { Evaluate Student Learning. } \\
\text { Autor: Van Eerden } K \\
\text { Fonte: Nursing and Health Care } \\
\text { Perspectives }\end{array}$ & $\begin{array}{l}\text { Utilizar vinhetas para avaliar a aquisição de } \\
\text { habilidades, comunicação terapêutica e } \\
\text { orientaçâao ao cliente. }\end{array}$ & Descritivo & $\begin{array}{l}\text { Foram desenvolvidas vinhetas para o programa, } \\
\text { num curso de nivel técnico. Os estudantes prepa- } \\
\text { ram as vinhetas, através da prática, dramatização e } \\
\text { demonstraçãa de ténnicas e simulacáao dos alunos } \\
\text { em laboratório orientados pelo professor. }\end{array}$ & $\begin{array}{l}\text { Houve melhora das habilidades } \\
\text { técnicas, de comunicacãao, solução de } \\
\text { problemas e pensamento crítico. }\end{array}$ & Não especifica \\
\hline $\begin{array}{l}\text { Using humor to teach postpartum topics } \\
\text { Autor: Graceffa } D \\
\text { Fonte: Journal of Nursing Education }\end{array}$ & $\begin{array}{l}\text { Descrever duas estratégias utilizadas no ensino } \\
\text { de enfermagem para alunos do curso de } \\
\text { enfermagem. }\end{array}$ & Descritivo & $\begin{array}{l}\text { Através da dramatizacaão, os alunos demonstram } \\
\text { técnicas de banho do recém nascido, orientaçōos } \\
\text { dos cuidados maternos, à criança e à familia. }\end{array}$ & $\begin{array}{l}\text { A atividade auxiliou no aprendizado ao } \\
\text { promover um ambiente tranqüilo. }\end{array}$ & Saúde da Mulher \\
\hline
\end{tabular}


Quadro 4 - Lista dos estudos incluídos, São Paulo - 2007. (conclusão)

\begin{tabular}{|c|c|c|c|c|c|}
\hline Artigo & Objetivo & $\begin{array}{l}\text { Tipo de } \\
\text { estudo }\end{array}$ & Metodologia & Resultados & Área \\
\hline $\begin{array}{l}\text { Using role play to develop cultural } \\
\text { competence } \\
\text { Autor: Shearer R, Davidhizar R } \\
\text { Fonte: Journal of Nursing Education }\end{array}$ & $\begin{array}{l}\text { Discutir a dramatização como estratégia de } \\
\text { ensino. }\end{array}$ & Descritivo & $\begin{array}{l}\text { Descrição de uma abordagem geral sobre a } \\
\text { dramatização como estratégia de ensino, tendo } \\
\text { Moreno como referencial teórico. }\end{array}$ & $\begin{array}{l}\text { A participação dos alunos foi efetiva, } \\
\text { entusiasmada, atingiu os objetivos e } \\
\text { contribuindo no preparo do estudante } \\
\text { para a prática profissional. }\end{array}$ & Não especifica \\
\hline $\begin{array}{l}\text { Using simulation to prepare students for } \\
\text { their qualified role } \\
\text { Autor: Bland A, Sutton A } \\
\text { Fonte: Nurs Times }\end{array}$ & $\begin{array}{l}\text { Desenvolver as competências e habilidades na } \\
\text { solução de problemas no ambiente de simulação. }\end{array}$ & Descritivo & 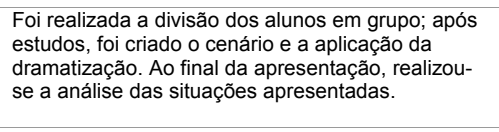 & $\begin{array}{l}\text { Os alunos relataram que a experiência } \\
\text { foi positiva, proporcionou habilidades } \\
\text { para solução dos próprios problemas } \\
\text { e conferiu experiência nas situações } \\
\text { simuladas. }\end{array}$ & Não especifica \\
\hline $\begin{array}{l}\text { Value teaching in nursing education } \\
\text { Autor: Czmowski M } \\
\text { Fonte: Nurs Forum }\end{array}$ & $\begin{array}{l}\text { Utilizar estratégias de ensino que estimulem o } \\
\text { desenvolvimento de valores no aspecto moral e } \\
\text { ético. }\end{array}$ & Descritivo & $\begin{array}{l}\text { Trata-se de uma reflexão sobre as estratégias de } \\
\text { ensino em enfermagem e o estimulo no } \\
\text { desenvolvimento de valores do estudante. }\end{array}$ & $\begin{array}{l}\text { A dramatização pode auxiliar no } \\
\text { desenvolvimento de valores, } \\
\text { propiciando a discussãa e análise } \\
\text { desses valores relacionando à vida } \\
\text { profissional. Estimula a solução de } \\
\text { problemas, planejamento da } \\
\text { assistência, mostrando-se um método } \\
\text { de ensino muito eficaz. }\end{array}$ & Não especifica \\
\hline $\begin{array}{l}\text { A bolsa na mediação estar ostomizado e } \\
\text { estar profissional: análise de uma } \\
\text { estratégia de ensino } \\
\text { Autor: Santos VL, Sawaia BB } \\
\text { Fonte: Rev Latino-Americano de } \\
\text { Enfermagem }\end{array}$ & $\begin{array}{l}\text { Analisar a (re)construção da significação sobre a } \\
\text { ostomia, o ostomizado, o cuidar em enfermagem } \\
\text { e o papel do enfermeiro. }\end{array}$ & Relato de caso & $\begin{array}{l}\text { Foi proposta aos } 30 \text { alunos do curso de } \\
\text { especialização em estomaterapia, vivenciarem uma } \\
\text { situaçãáo análoga ao do indivividuo ostomizado, } \\
\text { permanecendo com a bolsa coletora durante o } \\
\text { curson inclusive no cotidiano. A análise dos } \\
\text { depoimentos revelaram dois grandes eixos } \\
\text { discursivos: estar ostomizado e estar profissional. }\end{array}$ & $\begin{array}{l}\text { O uso da estratégia propiciou } \\
\text { reflexões no profissional acerca da } \\
\text { violação das condições na vida do } \\
\text { indivíuo ostomizado quanto à } \\
\text { imagem corporal, auto estima, } \\
\text { sexualidade, relações sociais, bem } \\
\text { como transformar o fazer técnico no } \\
\text { cuidar holístico, onde o simbólico e o } \\
\text { afetivo são valorizados numa } \\
\text { experiência singular. }\end{array}$ & Estomaterapia \\
\hline
\end{tabular}




\section{RESULTADOS E DISCUSSÃO}




\section{RESULTADOS E DISCUSSÃO}

Foram encontrados 541 estudos, dos quais 477 foram excluídos por não obedecerem aos critérios de inclusão estabelecidos, por repetição e 64 foram incluídos. Outro fator que colaborou para a exclusão de estudos refere-se aos descritores empregados. Constatou-se que, ao utilizar o descritor "simulação / simulation", muitos estudos foram encontrados e excluídos, pois descreviam sobre o uso de computador e aplicação de ferramentas tecnológicas, como softwares educacionais. Entretanto, tal condição já havia sido prevista quando decidimos manter o descritor para não comprometer a sensibilidade das buscas.

Outro fator relacionado com a exclusão de estudos localizados por meio desse descritor foi o sentido de simulação de técnicas em laboratório, o que não tinha relação com dramatização. Identificou-se também que, apesar da realização das buscas com a expressão "role playing", vários estudos foram encontrados por conter os termos "role" e/ou "play" e, como não diziam respeito à dramatização, foram excluídos.

Os 64 estudos incluídos foram analisados sob os aspectos definidos no protocolo de busca, como: ano de publicação, país de origem, a fonte de publicação, o nível do curso da população, o desenho metodológico, a área de aplicação da dramatização, a categorização dos resultados e as dificuldades na utilização da dramatização. 
Tabela 1- Distribuição dos estudos encontrados segundo o ano de publicação, São Paulo - 2007.

\begin{tabular}{|c|c|c|}
\hline Ano & $\mathrm{N}^{\circ}$ de estudos & $\%$ \\
\hline 1973 & 1 & $2 \%$ \\
\hline 1974 & 1 & $2 \%$ \\
\hline 1977 & 1 & $2 \%$ \\
\hline 1979 & 1 & $2 \%$ \\
\hline 1982 & 1 & $2 \%$ \\
\hline 1984 & 1 & $2 \%$ \\
\hline 1986 & 1 & $2 \%$ \\
\hline 1987 & 1 & $2 \%$ \\
\hline 1990 & 1 & $2 \%$ \\
\hline 1991 & 1 & $2 \%$ \\
\hline 1992 & 2 & $3 \%$ \\
\hline 1993 & 2 & $3 \%$ \\
\hline 1994 & 1 & $2 \%$ \\
\hline 1995 & 1 & $2 \%$ \\
\hline 1996 & 1 & $2 \%$ \\
\hline 1997 & 2 & $3 \%$ \\
\hline 1998 & 2 & $3 \%$ \\
\hline 1999 & 2 & $3 \%$ \\
\hline 2000 & 6 & $9 \%$ \\
\hline 2001 & 4 & $6 \%$ \\
\hline 2002 & 4 & $6 \%$ \\
\hline 2003 & 6 & $9 \%$ \\
\hline 2004 & 8 & $13 \%$ \\
\hline 2005 & 9 & $14 \%$ \\
\hline 2006 & 4 & $6 \%$ \\
\hline TOTAL & 64 & $100 \%$ \\
\hline
\end{tabular}

A tabela 1 indica que, dentre os 64 (100\%) estudos selecionados, verificou-se que, nos anos de 2004 e 2005, houve um número maior de publicações relacionadas com o tema desta investigação, respectivamente 8 (13\%) e 9 (14\%), evidenciando o aumento gradativo do interesse pela aplicação da dramatização como recurso educacional. Observamos que, inicialmente, a utilização da dramatização era mais freqüente no ambiente profissional e que, mais tarde, passou a ser aplicada no processo educativo, 
refletindo a preocupação dos docentes e orientadores pedagógicos em buscar instrumentos que favorecessem a aprendizagem.

Verificamos, também, que essa preocupação motivou a busca em diferentes dimensões geográficas, ultrapassando barreiras continentais, e identificamos a presença dessa estratégia no processo educativo de vários países.

Os dados referentes à distribuição dos estudos encontrados segundo o país de origem estão apresentados na figura 1.

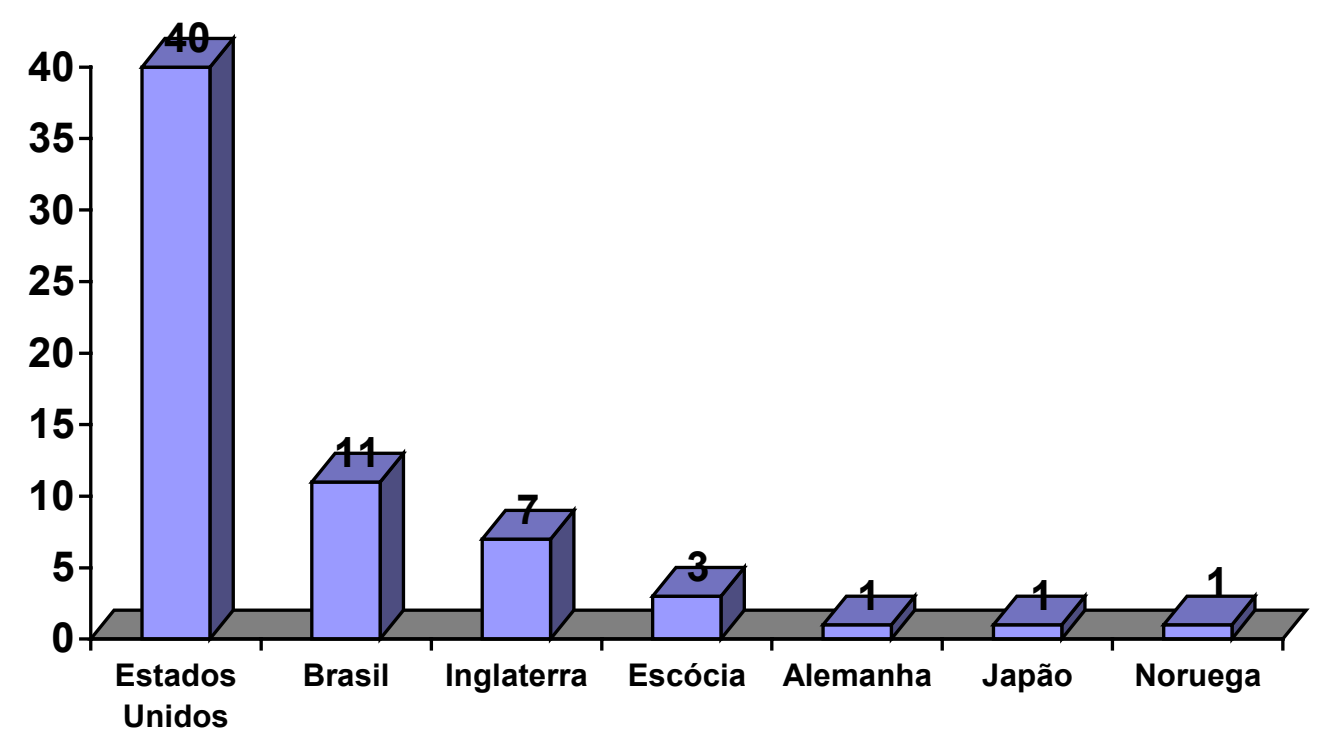

Figura 1- Distribuição dos estudos encontrados segundo o país de origem, São Paulo - 2007.

A figura 1 mostra que, dos 64 (100\%) estudos incluídos, os Estados Unidos foram o país responsável pela maioria das publicações encontradas, com um total de 40 (63\%) artigos. Entretanto, na distribuição internacional, constatou-se que essa estratégia é utilizada em diversos países de culturas extremamente diferentes, mas apresentando em comum a opção pelo uso da dramatização no ensino em Enfermagem. 
$\mathrm{Na}$ busca dos estudos efetuados, realizada nas bases eletrônicas e manualmente, a veiculação dos trabalhos encontrados sobre a dramatização ocorreu de diversas maneiras, como apresenta a tabela 2.

Tabela 2- Distribuição dos estudos encontrados segundo a fonte de publicação dos estudos, São Paulo - 2007.

\begin{tabular}{|c|c|c|}
\hline Fonte & $\mathrm{N}^{\circ}$ de estudos & $\%$ \\
\hline Nurse Educator & 17 & $27 \%$ \\
\hline Journal of Nursing Education & 12 & $19 \%$ \\
\hline Nurse Education Today & 3 & $5 \%$ \\
\hline Nursing Standard & 2 & $3 \%$ \\
\hline Revista Paulista de Enfermagem & 2 & $3 \%$ \\
\hline Revista Brasileira de Enfermagem & 2 & $3 \%$ \\
\hline Nurs Times & 2 & $3 \%$ \\
\hline Journal of Psychosocial Nursing \& Mental Health Services & 1 & $2 \%$ \\
\hline Journal of Family Nursing & 1 & $2 \%$ \\
\hline Journal of Advanced Nursing & 1 & $2 \%$ \\
\hline Journal of UOEH & 1 & $2 \%$ \\
\hline Health Education Monographs & 1 & $2 \%$ \\
\hline Dissertação Mestrado (UFRJ) & 1 & $2 \%$ \\
\hline Deutsche Krankenpflegezeitschrift & 1 & $2 \%$ \\
\hline Cogitare & 1 & $2 \%$ \\
\hline Br J Nurs & 1 & $2 \%$ \\
\hline AORN Journal & 1 & $2 \%$ \\
\hline J. Cancer Education & 1 & $2 \%$ \\
\hline Nurs Educ Perspect & 1 & $2 \%$ \\
\hline $57^{\circ}$ Congresso Brasileiro de Enfermagem & 1 & $2 \%$ \\
\hline Nurs Outlook & 1 & $2 \%$ \\
\hline West J Nurs Res & 1 & $2 \%$ \\
\hline Nursing and Health Care Perspectives & 1 & $2 \%$ \\
\hline Paediatr Nurs & 1 & $2 \%$ \\
\hline Rev. Enfermagem UERJ & 1 & $2 \%$ \\
\hline Revista Gaúcha de Enfermagem & 1 & $2 \%$ \\
\hline Revista Latino-Americana de Enfermagem & 1 & $2 \%$ \\
\hline Revista Latino-Americano de Enfermagem & 1 & $2 \%$ \\
\hline Sykepleien & 1 & $2 \%$ \\
\hline The Journal of nursing education & 1 & $2 \%$ \\
\hline Nurs Forum & 1 & $2 \%$ \\
\hline TOTAL & 64 & $100 \%$ \\
\hline
\end{tabular}

Na tabela 2, verifica-se que, dos $64(100 \%)$ estudos publicados por diversas fontes (em sua maioria, periódicos norte-americanos), 17 (27\%) 
foram publicados pela revista Nurse Educator e 12 (19\%) foram veiculados pela revista Journal of Nursing Education.

Além da revista impressa, em que se encontrou a maioria dos estudos, as informações sobre a dramatização como foco principal foram obtidas em revistas eletrônicas, evidenciando a existência de diversos veículos para a obtenção e divulgação dos resultados das pesquisas.

Os cursos de Enfermagem contribuem para a formação de profissionais de diferentes níveis da equipe de Enfermagem. Em nossas buscas, constatamos que a estratégia foi aplicada em níveis distintos na formação profissional em Enfermagem, como ilustra a figura 2.

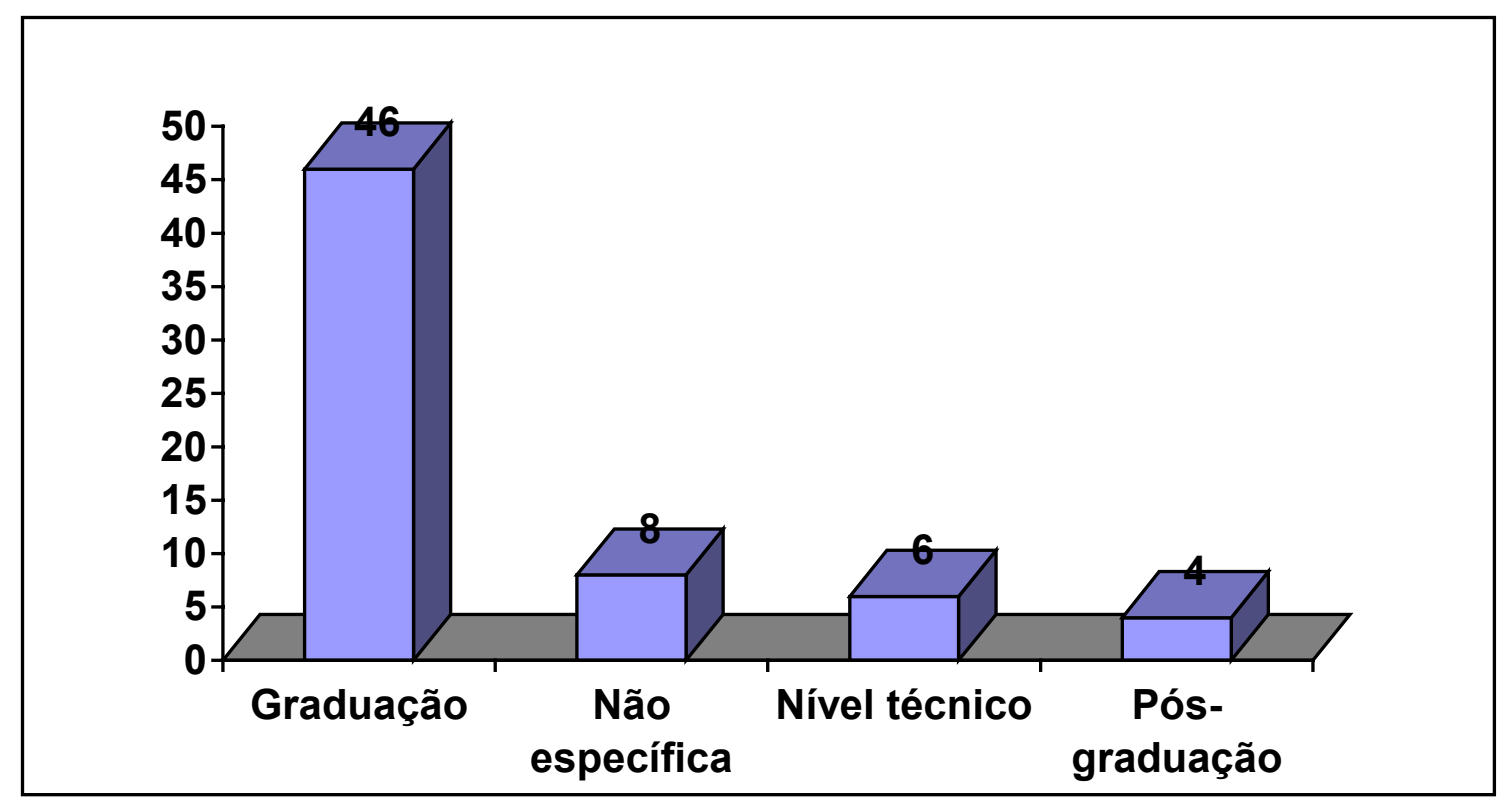

Figura 2- Distribuição dos estudos encontrados segundo o nível de formação profissional da população estudada, São Paulo - 2007.

A figura 2 ilustra que, dentre os 64 (100\%) estudos selecionados, a maioria, ou seja, 46 (72\%), diz respeito à aplicação da dramatização no curso de graduação em Enfermagem. 
Em cada nível de formação profissional, as abordagens dos conteúdos são diferentes quanto à complexidade; porém, os achados demonstraram que não inviabilizaram a adoção da dramatização. Mediante os ajustes necessários em função dos fatores que influenciam o processo de ensino e aprendizagem, a estratégia pode ser utilizada inclusive no ensino de pesquisa em Enfermagem, num curso de pós-graduação ${ }^{(75)}$.

A presente investigação verificou a utilização de diversos desenhos metodológicos dentre os estudos encontrados, como pode ser observado na figura 3.

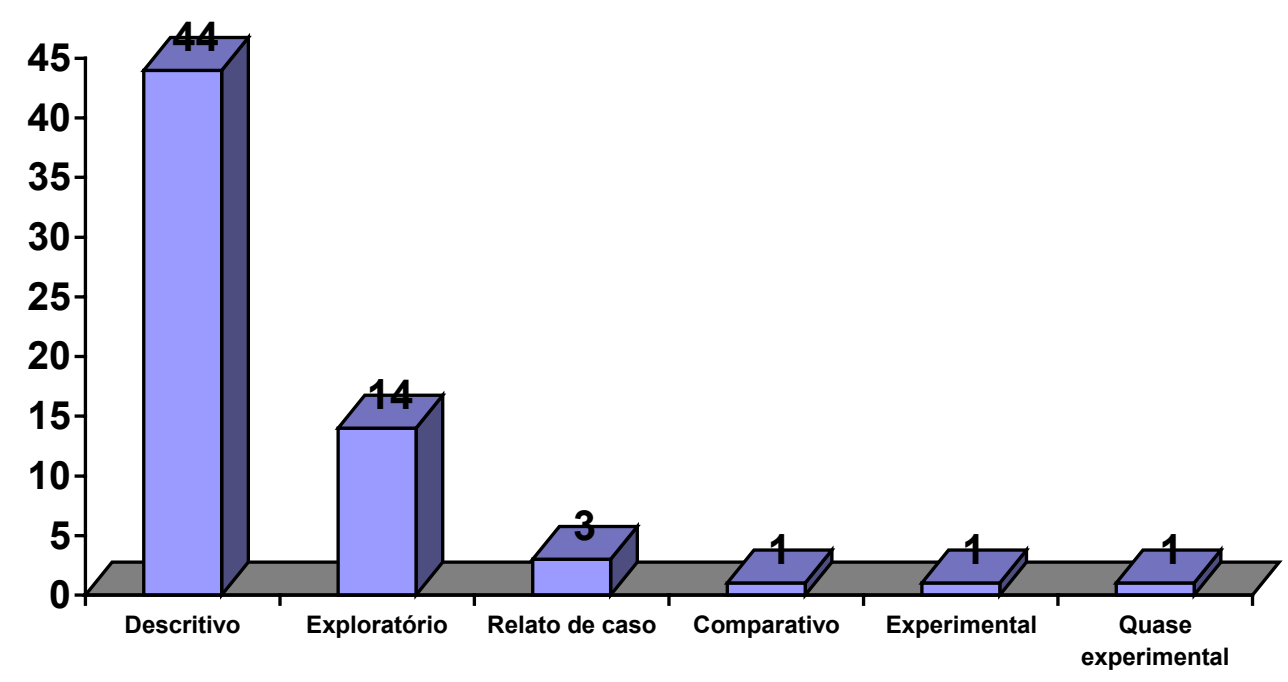

Figura 3 - Distribuição dos estudos encontrados segundo 0 desenho metodológico, São Paulo - 2007.

No que se refere ao desenho metodológico dos 64 (100\%) estudos selecionados, verificou-se que 44 (69\%) eram constituídos de investigações que utilizaram o do tipo descritivo, em que os autores descrevem suas idéias sobre o tema analisando, criticando, expondo ou descrevendo experiências.

Segundo os vários objetivos dos autores dos estudos encontrados, verificamos que a dramatização foi aplicada nas mais diversas áreas do conhecimento. Essas áreas estão apresentadas na tabela 3. 
Tabela 3 - Distribuição dos estudos encontrados segundo a área de aplicação da dramatização, São Paulo - 2007.

\begin{tabular}{lcc}
\hline Área & $\mathbf{N}^{\circ}$ de estudos & $\%$ \\
\hline Administração em Enfermagem & 2 & $3 \%$ \\
Anatomia e Fisiologia do Sistema Cardiorrespiratório & 1 & $2 \%$ \\
Educação & 1 & $2 \%$ \\
Emergência & 1 & $2 \%$ \\
Enfermagem em Clínica Médica & 1 & $2 \%$ \\
Enfermagem em Oncologia & 1 & $2 \%$ \\
Estomaterapia & 1 & $2 \%$ \\
Ética Profissional & 2 & $3 \%$ \\
Geriatria & 1 & $2 \%$ \\
História da Enfermagem & 2 & $3 \%$ \\
Introdução à Enfermagem & 2 & $3 \%$ \\
Oncologia & 1 & $2 \%$ \\
Reabilitação & 1 & $2 \%$ \\
Saúde Coletiva & 1 & $2 \%$ \\
Saúde da Criança & 1 & $2 \%$ \\
Saúde da Família & 1 & $2 \%$ \\
Saúde da Mulher & 6 & $9 \%$ \\
Saúde do Trabalhador & 1 & $2 \%$ \\
Saúde Mental & $5 \%$ \\
Terapia Intensiva & 1 & $2 \%$ \\
Não especifica & 31 & $48 \%$ \\
\hline TOTAL & 64 & $100 \%$ \\
\hline & & \\
& 1 & $2 \%$ \\
\hline
\end{tabular}

A tabela 3 indica que, dentre os $64(100 \%)$ estudos incluídos neste trabalho, 31 (48\%) não especificaram a área correspondente dos estudos em questão; entretanto, verificou-se que a dramatização foi utilizada nos mais variados campos do saber, evidenciando a flexibilidade de aplicação dessa estratégia.

$\mathrm{Na}$ formação profissional em Enfermagem, essa versatilidade nos permite encontrá-la em diversas áreas e em diferentes períodos do curso. Nossa experiência mostra-nos que, nas etapas iniciais do curso, é necessário ser mais cauteloso quanto à aplicação da dramatização; de maneira intuitiva e coerente, mas fundamentando-se nos preceitos teóricos, 
é necessário, inicialmente, conhecer os alunos e as suas expectativas. De posse dessas informações, realizamos o diagnóstico inicial do grupo, traçamos o seu perfil para, então, decidir quando e como aplicar a referida estratégia. Esses pequenos mas importantes cuidados são fundamentais na definição dos resultados quando se utiliza a dramatização no processo educativo.

Os estudos encontrados mostram diferentes percepções dos autores sobre a aplicação da dramatização como um recurso positivo no processo de ensino e aprendizagem. A categorização dos resultados estão apresentados na tabela 4 .

Tabela 4 - Distribuição dos estudos encontrados segundo a categorização dos resultados, São Paulo- 2007.

\begin{tabular}{lcc}
\hline Resultados & $\mathbf{N}^{\circ}$ de estudos\% & $\%$ \\
\hline Resultado positivo & 64 & $100 \%$ \\
Melhora na teoria & 49 & $77 \%$ \\
Facilita a associação teoria-prática & 42 & $66 \%$ \\
Estimula o pensamento crítico & 29 & $45 \%$ \\
Favorece o relacionamento interpessoal & 19 & $30 \%$ \\
Desenvolve habilidades & 14 & $22 \%$ \\
Melhora na comunicação & 11 & $17 \%$ \\
Propicia um ambiente favorável & 8 & $13 \%$ \\
Estímulo à criatividade & 5 & $8 \%$ \\
Contribui na tomada de decisão & 5 & $8 \%$ \\
Colabora no desempenho do estágio & 4 & $6 \%$ \\
\hline
\end{tabular}

$\mathrm{Na}$ tabela 4, verificamos que, em sua totalidade, os 64 (100\%) estudos selecionados relataram resultados positivos obtidos com a utilização da dramatização, sendo que 49 (77\%) associaram o resultado positivo à aquisição de conhecimento teórico e 42 (66\%) descreveram a melhora na associação teoria e prática após a aplicação da estratégia. Esses achados refletem a relação positiva da dramatização como estratégia facilitadora no 
processo educativo, além de contribuir em diversos aspectos importantes da formação do futuro profissional em Enfermagem, relacionados com 0 desenvolvimento de habilidades, reconhecimento e associação de informações de outros componentes curriculares através da interdisciplinaridade.

Os estudos encontrados descreveram, ainda, que a dramatização possibilitou o estímulo da criatividade dos estudantes, favoreceu a melhoria do relacionamento interpessoal, do aspecto comunicacional, do pensamento crítico, contribuiu para a percepção e desenvolvimento do senso de coletividade e do trabalho em grupo, bem como do comportamento ético profissional.

A nossa experiência profissional, somada agora a essa categorização dos resultados, reforça a certeza de que a dramatização é uma grande aliada do docente quando se quer trabalhar não só os aspectos éticos do futuro profissional, mas também todos os outros evidenciados na tabela acima. E, quando o mercado de trabalho e a própria sociedade exigem um profissional competente, com domínio dos quatro saberes (saber saber, saber fazer, saber ser e saber conviver), a dramatização mostra-se um recurso didático que facilita a interligação desses saberes e permite que os alunos desenvolvam a plena formação profissional.

A utilização da dramatização no processo educativo gera a espontaneidade, cria o desafio de transpor os conteúdos teóricos, propicia a aprendizagem através da ação e interação, construindo e reconstruindo o conhecimento. O jogo dramático é elaborado como um processo de conhecimento e desenvolvimento pessoal, de forma a criar, descobrir e conhecer. $\mathrm{O}$ indivíduo estabelece, assim, novas relações com os outros e com o mundo que o rodeia, o que possibilita que o aluno e o docente trabalhem em situações que envolvem o enfrentamento e a solução de problemas, num processo de participação espontânea e renovada.

A experiência decorrente do fazer cotidiano do professor constitui um saber pedagógico que deve ser valorizado e, mais do que isso, utilizado a 
serviço de estratégias de ensino que proporcionem ações transformadoras. Não basta, porém, ser uma pessoa criativa para inovar na sala de aula. A prática da inovação no ambiente educacional é conseqüência de uma situação que a provoque. Algumas tentativas de inovação nas estratégias de ensino decorrem mais da visão e compromisso do educador ou de um grupo deles, os quais defendem um ensino crítico e libertador. Não temos dúvida de que, pela própria formação, o educador é possivelmente o maior conhecedor do assunto na área de Enfermagem; mas, por outro lado, nos perguntamos se a sua forma de ensinar é a mais adequada e se atende às reais necessidades dos alunos e ao perfil do grupo.

Infelizmente, nem todos os docentes estão abertos às mudanças na sua "rotina de ensinar". A resistência desses profissionais tem como elemento articulador a inovação, gerando uma crise de identidade que põe em questão a sua missão na formação educacional.

Nas escolas, sob a denominação de inovação, incluem-se não só mudanças curriculares, mas também a introdução de novos processos de ensino e aprendizagem, de produtos, matérias, idéias e pessoas. Contudo, ao considerar inovação como "uma série de mecanismos e processos que são o reflexo mais ou menos deliberado e sistemático por meio do qual se pretende introduzir e promover certas mudanças nas práticas educativas vigentes" (76), verificamos que é o reflexo de uma série de dinâmicas explícitas que pretendem alterar idéias, concepções e metas, conteúdos e práticas escolares, em alguma direção renovadora em relação à existente.

As estratégias consideradas inovadoras pelo professor, perturbam a ordem de suas identidades e promovem movimentos antagônicos concretizados pela contestação. Alguns professores não aceitam e contestam, talvez porque não conseguem, inicialmente, introduzir uma mudança na prática diária da classe. Mas quando, finalmente, percebem a nova forma de ministrar a aula, compreendem que não modificaram a essência de seu trabalho pedagógico ${ }^{(77)}$; mas, sim, que contribuíram para a transformação do saber do aluno agregando o seu saber de docente. $O$ 
desejo constante de avançar e a aspiração pelo progresso o impelem à pesquisa dos meios para se aprimorar, impulsionando-o às novas descobertas, ao aperfeiçoamento.

Nesse sentido, se os enfermeiros educadores reformularem sua visão do processo de ensino e de aprendizagem, dando ênfase ao desenvolvimento efetivo do espírito crítico, possibilitando ao aluno desenvolver sua capacidade analítica, crítica, reflexiva ao ser instigado a questionar, investigar, divergir, argumentar e experimentar poderão contribuir para a renovação da profissão e dar conta dos novos desafios. $O$ profissional não é aquele que apenas executa sua profissão, mas, sobretudo aquele que sabe pensar e refazer sua profissão. ${ }^{(78)}$

Conforme vai desenvolvendo a sua capacidade analítica e reflexiva, o estudante irá estender essa prática à filosofia e aos objetivos da instituição educacional, à prática docente e à qualidade do ensino recebido. Para tais questões, o corpo docente e o administrativo da escola devem ser receptivos a essa nova postura dos alunos, bem como devem saber gerenciar os conflitos que advêm do ensino crítico e repercutem sobre a diretriz escolar vigente.

O exercício de analisar, sugerir e, ao mesmo tempo, receber as críticas e respeitar opiniões diversas, dará subsídios ao aluno para lidar com novos desafios e, dessa forma, contribuir para a renovação da profissão. A inovação em sala de aula é, pois, uma resposta criativa e bem-sucedida a uma situação-problema. O seu ponto de partida deve ser, portanto, o corpo discente, suas necessidades e possibilidades, suas expectativas. Esse conhecimento contribui para a construção das ações pedagógicas como um balizador do trabalho do professor. A aceitação e a adesão a uma nova proposta dependerão daquilo que os discentes têm condições de realizar, desde que a proposta não exija esforços indisponíveis que podem acarretar desempenhos insatisfatórios dos alunos. Para implementar estratégias de ensino inovadoras, faz-se necessário provocar uma ruptura no comportamento habitual dos discentes, principalmente quando as 
experiências anteriores de aprendizado eram situadas sob a égide da educação tradicional. Refletir sobre quais mudanças serão necessárias para o sucesso da inovação proposta e explicitar o processo da dinâmica das aulas e os objetivos traçados podem contribuir para o sucesso das inovações pretendidas.

A necessidade de perceber criticamente as possibilidades e limitações de cada proposta pela busca de modelos de ensino e aprendizagem que respondam às expectativas da comunidade docente vale-se da análise de seus fundamentos teóricos e metodológicos, considerando, ainda, as condições reais da instituição, as características do curso e das diferentes disciplinas que o integram, as metas e princípios pedagógicos que orientam o processo de formação, além da organização curricular e o trabalho do professor em sala de aula, para lidar com as demandas por mudança. Experiências pedagógicas, aparentemente pontuais, geradas no contexto dos conflitos e das contradições das relações institucionais, voltadas para a mudança de processos, relações e conteúdos, podem representar um movimento inovador em termos do processo de reelaboração de um conhecimento mais significativo para os alunos, favorecendo rupturas com o modelo tradicional de ensino, capazes de levar a movimentos mais amplos de mudança ${ }^{(79)}$.

Em relação ao fator comunicacional, verificamos que a dramatização estimula o aparecimento do interior e, ao mesmo tempo da interação do grupo e proporciona oportunidades para a linguagem: a linguagem do corpo, dos sentidos, das emoções, a linguagem das palavras. Coloca grandes exigências em relação à concentração individual e do grupo, estimula o escutar - não somente ouvir, mas um escutar que antecipa a resposta. Evans ${ }^{(80)}$ considera determinante o desenvolvimento das habilidades comunicacionais na área da Enfermagem ao descrever uma atividade em que os alunos simulam condições de portadores de deficiência visual, auditiva e vocal, estimulando as diferentes maneiras que podem ser exploradas no desenvolvimento dessas habilidades. 
Além de ser uma estratégia facilitadora do processo de comunicação, a dramatização permite ao estudante estabelecer uma associação de múltiplos fatores que influenciam as situações, analisando criticamente e vislumbrando as possíveis intervenções que podem contribuir como soluções prováveis da questão. Ao aplicar essa estratégia, é possível promover a inserção da problematização, ou seja, da aprendizagem baseada em problemas. Na prática educativa, tem tido importantes repercussões nas escolas da área da saúde, não apenas pela própria inovação mas, principalmente, pelas contribuições que proporciona ao estimular o raciocínio lógico, a mobilização do saber interdisciplinar, a busca de respostas ao desafio, a assertividade, a implantação de propostas, a resolutividade, sem menosprezar os aspectos sócio-político-econômicos que permeiam a realidade ${ }^{(81)}$.

Esses mecanismos desencadeiam o pensamento crítico pela prática diária que sinaliza a ocorrência de um fluxo de comunicação que não se efetiva em mão única, mas tem um caráter interativo, de ação recíproca. Significa uma mudança de postura para o exercício de um trabalho reflexivo do aluno, exigindo a disponibilidade do professor para pesquisar, para acompanhar e colaborar no aprendizado crítico do estudante. Situações imprevistas, novas e desconhecidas, exigem que professores e alunos compartilhem o processo de construção (e não apenas o de reconstrução e reelaboração) do conhecimento. O educador em Enfermagem deve refletir sobre esses aspectos que visam a desenvolver o pensamento crítico dos alunos, com o propósito de também promover a liderança em Enfermagem. Os processos dinâmicos de perguntar, de raciocinar, de questionar os postulados prontos, contribuem para o desenvolvimento da forma de pensar (82).

Concordamos com Lima ${ }^{(83)}$ ao comentar que

a educação no Brasil está sendo convocada para demonstrar qualidade e eficácia, e o desenvolvimento do pensamento crítico tem sido considerado como um fator de eficácia na busca da excelência na formação profissional e a literatura de enfermagem espelha a necessidade de desenvolver o pensamento crítico, visto que pensar criticamente abre portas para novas 
perspectivas sobre o mundo, promove autoconfiança, encoraja o aprendizado para toda a vida e é uma das atividades mais significativas da vida adulta. Portanto, o pensamento crítico é objeto de estudo para entender o estado da arte na educação em Enfermagem.

A atuação na área da Enfermagem requer do futuro profissional a capacidade de transformação, a competência para enfrentar os desafios e solucionar problemas de maneira habilidosa, pois o foco das ações está voltado para o ser humano. Os recursos individuais do estudante são mobilizados durante a dramatização pela reorganização das informações e tomada de decisões, aguçando a percepção de si mesmo e do outro ${ }^{\left({ }^{84}\right)}$. Diversos autores descrevem a importância do aluno e até mesmo do profissional desenvolver tal percepção, reforçando a relação com o outro de maneira consciente. A dramatização utilizada nesse sentido provoca profundas reflexões, pois, ainda que por alguns instantes, o estudante vivencia as dificuldades e limitações daquele que estará sob seus cuidados.

Williams ${ }^{(85)}$ propôs aos alunos uma atividade em duplas para encenação de situações; ao vendar os olhos do colega, o seu par deve orientá-lo na caminhada pela rua; em outra dupla, o portador de deficiência física necessita do auxílio do seu par para se locomover e ser conduzido de maneira segura. E assim, criando várias situações a partir da realidade, os alunos perceberam as dificuldades e limitações dos deficientes físicos, a importância de saber se comunicar de forma efetiva, identificando sinais na comunicação não verbal que expressam os sentimentos e ansiedades do outro, além das lacunas nas políticas públicas quanto à (des) atenção com essa parcela da população.

Essas situações promovem a mobilização do senso crítico, a organização do processo comunicacional, o desenvolvimento do senso de coletividade e da capacidade de trabalho em grupo. Vivenciando esse processo, os estudantes compreendem não apenas a atuação profissional em Enfermagem, mas também valores éticos e de cidadania, de forma lúdica e prazerosa, em um ambiente tranqüilo para o aprendizado. Buscando um equilíbrio entre os aspectos cognitivos, técnicos e afetivos no processo 
de ensino e aprendizagem na educação em Enfermagem, somos como educadores, agentes catalisadores no processo. Alcançar esses aspectos por intermédio da formação exige mais do que a transmissão dos conteúdos programáticos; requer todo um conjunto de ações e procedimentos de todos os elementos do processo educativo, através da articulação entre os envolvidos no processo pedagógico.

Visando à construção do conhecimento, à aprendizagem de novos papéis e de novas atitudes, as práticas pedagógicas podem colaborar na concretização de propostas que transformam as concepções de mundo e de sociedade. A dramatização apresenta-se como um caminho metodológico facilitador nessa construção e abre numerosas possibilidades de aplicação no campo da formação do futuro profissional, pois é o momento em que a sensibilidade e a espontaneidade se fazem presentes na prática educativa. Consideramos como ponto de partida inicial na utilização da estratégia o preparo do professor que a aplicará, de modo que possa conhecer os conceitos e a estrutura da dramatização, a sua aplicabilidade, as suas conseqüências e limitações para que a vivência não se transforme em uma aventura, mas se configure como alternativa efetiva no processo de ensino e aprendizagem.

Dentre os resultados dos estudos encontrados, também foram descritas as dificuldades encontradas pelos autores na utilização da dramatização, apresentadas na tabela 5. 
Tabela 5 - Distribuição dos estudos encontrados segundo as dificuldades para aplicação da dramatização, São Paulo - 2007.

\begin{tabular}{lcc}
\hline Dificuldade & $\mathbf{N}^{\circ}$ de estudos & $\%$ \\
\hline Limitação do estudo quanto ao tipo de amostra & 2 & $3,1 \%$ \\
(conveniência) & 1 & $1,6 \%$ \\
Desconforto na exposição ao grupo & 1 & $1,6 \%$ \\
Dificuldade em estabelecer prioridades & 1 & $1,6 \%$ \\
Relacionamento entre os alunos (ansiedade) & 1 & $1,6 \%$ \\
Tempo curto para a atividade & 1 & $1,6 \%$ \\
Não contribuiu para melhorar a perspectiva & 1 & $1,6 \%$ \\
profissional & 8 & $13 \%$ \\
Não foi significante a melhora do pensamento crítico & & \\
\hline TOTAL & \multicolumn{2}{c}{} \\
\hline
\end{tabular}

Segundo a tabela 5, dentre os $64(100 \%)$ estudos investigados, 8 (13\%) autores teceram comentários sobre alguma dificuldade detectada ante a atividade dramatizada. Dentre os estudos que explicitam algum grau de dificuldade na aplicação da dramatização, os aspectos relatados estavam associados à limitação da população envolvida no estudo, por ser uma amostra de conveniência e dificultar a generalização dos resultados. Em relação ao aluno, foi observado certo desconforto frente aos colegas pelo medo de exposição diante do grupo; na conclusão final da referida investigação, o autor mencionou a importância da intervenção cuidadosa do professor, a fim de dirimir as dúvidas e dissipar os preconceitos, evidenciando os objetivos da estratégia na aprendizagem e o senso de respeito ao indivíduo.

Em outro estudo, verificou-se que os alunos apresentavam dificuldades em estabelecer prioridades e discernir o que é relevante ou não na formação profissional. Entendemos que a aprendizagem é um processo e 
que cada etapa percorrida na jornada educativa propicia, além de conhecimento, a maturidade daquele que vai se conscientizando do seu futuro profissional. Gradativamente, o discernimento em relação às prioridades e relevâncias na formação favorece a compreensão, proporcionando maior segurança nas decisões.

Outra dificuldade relatada diz respeito à ansiedade e à solicitação dos alunos, que manifestaram a necessidade de mais tempo para realizar a atividade; nesse caso, foi necessário que o professor mostrasse aos estudantes a importância de se aprender a administrar o tempo disponível para a realização da dramatização conforme o planejamento da atividade, visando a respeitar o cronograma escolar. No entanto, verificamos que essa situação é comum no universo escolar.

Um autor comentou sobre dificuldades iniciais associadas ao relacionamento entre os alunos; porém, a questão foi conduzida de maneira habilidosa pelo professor, promovendo um clima de tranqüilidade para a concretização da atividade.

Outro estudo verificou que a dramatização não contribuiu para melhorar a perspectiva profissional do grupo; nessa investigação, foram relatados inúmeros resultados positivos em relação à dramatização, mas destacou-se que a atividade não modificou a perspectiva profissional que os estudantes apresentavam em relação à atuação na área de Enfermagem. Depreendeu-se que tal fato ocorreu devido ao interesse dos participantes em abordar outros temas, como relacionamento interpessoal e aspectos comunicacionais, mas o aspecto das expectativas profissionais não foi amplamente discutido pelo grupo.

Um autor concluiu que não foi significativa a melhora do pensamento crítico. Cabe ao professor identificar o motivo pelo qual o aluno não consegue estabelecer as associações entre o conteúdo apresentado com os anteriores e as relações a serem vinculadas, seja no plano profissional, seja no plano social, político ou econômico. Acreditamos que essa dificuldade pode advir da carência dos conhecimentos necessários para que tais 
conteúdos se tornem significativos ou do fato do estudante não estar mobilizado para uma aprendizagem ativa.

Um aluno expressou, em outro estudo, o sentimento de incapacidade para cuidar do paciente, porém, não foram explicitadas as medidas tomadas para solucionar ou amenizar essa questão.

Entendemos que tais aspectos podem ser considerados subjetivos, pois cada aluno tem necessidades diferentes em função da própria vivência e maturidade, da compreensão das próprias limitações e da percepção das suas potencialidades. Não raro nos deparamos com indivíduos que expressam aparente incapacidade de realização; mas, como educadores, percebemos que a falsa impressão do aluno pode ser vencida por meio do estímulo à sua autoconfiança e à sua auto-estima, impulsionando-o a descobrir as próprias potencialidades. Aproveitar as experiências e buscar aperfeiçoar-se configura oportunidades para esse desenvolvimento orientado para as possibilidades de desempenhar o novo papel ${ }^{(86)}$.

Para essas dificuldades apontadas pelos autores, assumimos nossa condição reflexiva sobre o verdadeiro educador que exercita, constantemente, a análise de sua prática pedagógica no seu cotidiano, com as seguintes perguntas: "Por que ensinar?", "Para quê?", "Para quem?", "Quais os resultados?".

Frente à inexistência de considerações sobre como alguns autores solucionaram as dificuldades, colocamos as seguintes questões: será que as dificuldades relatadas foram compreendidas pelos autores como fatores que poderiam propiciar o desenvolvimento de suas habilidades para superar os desafios ao utilizarem uma estratégia inovadora e contribuir para reflexão de suas práxis? Será que foram compreendidas como fatores negativos para a aplicação da dramatização no processo educativo? 


\section{LIMITAÇÕES DO ESTUDO}




\section{LIMITAÇÕES DO ESTUDO}

Foram encontrados e excluídos inúmeros estudos em que a amostra da pesquisa era constituída por profissionais (enfermeiros, docentes), pois a utilização da dramatização contribuía para o treinamento e educação continuada no trabalho. Esses escopos divergiam daqueles do presente estudo, cujo foco está centrado no processo de ensino e aprendizagem dos estudantes de Enfermagem, na fase de formação do futuro profissional.

Constatamos que ficaram implícitos na leitura dos artigos diversos aspectos positivos decorrentes da aplicação da dramatização, como a melhora da criatividade, a mudança de atitudes, o senso de coletividade e a percepção de ser agente de transformação. No entanto, os autores não explicitaram esses aspectos ao descreverem os resultados e conclusões, o que repercutiu na baixa porcentagem desses aspectos nos resultados encontrados.

Verificamos, em alguns artigos, a não especificação quanto ao conceito de dramatização, quanto à descrição das etapas na aplicação da estratégia, quanto à caracterização da área em que foi aplicada, bem como quanto à população estudada naquele momento. Consideramos a autonomia de escolha dos autores em construir o trabalho, dentro dos objetivos e das possibilidades inerentes no momento, respeitando os fatores externos à nossa análise. Mas essas questões nos remetem à reflexão sobre o nosso papel enquanto pesquisadores, em relação à importância da atenção e do rigor na realização e na descrição das investigações, ao nos propormos a contribuir não só para a comunidade científica como também para toda a sociedade. 


\section{CONCLUSÃO}




\section{CONCLUSÃO}

Foram encontrados 541 estudos, dos quais 477 foram excluídos por não obedecerem aos critérios de inclusão estabelecidos e 64 foram incluídos nesta pesquisa. Outro fator considerado para a exclusão diz respeito aos descritores empregados e repetição dos artigos identificados em mais de uma fonte.

Quanto ao ano de publicação, dentre os 64 (100\%) estudos selecionados, verificou-se que nos anos de 2004 e 2005 houve um maior número de publicações relativas ao tema desta investigação, respectivamente $8(13 \%)$ e $9(14 \%)$, evidenciando que, gradativamente, cresce o interesse pelo assunto.

Dos 64 (100\%) estudos incluídos, verificou-se que os Estados Unidos foram o país responsável pela maioria das publicações encontradas, com um total de $40(63 \%)$ artigos publicados.

Dentre os 64 (100\%) estudos publicados por diversas fontes, em sua maioria norte-americanos, $17(27 \%)$ foram publicados pela revista Nurse Educator e 12 (19\%) foram veiculados pela revista Journal of Nursing Education.

Os cursos de Enfermagem contribuem para a formação de profissionais de diferentes níveis da equipe de Enfermagem. Dos 64 (100\%) estudos selecionados, a maioria, isto é, 46 (72\%), está relacionada com aplicação da dramatização no curso de graduação em Enfermagem.

Quanto ao desenho metodológico dos 64 (100\%) estudos selecionados, verificou-se que 44 (69\%) eram constituídos de investigações que utilizaram o tipo descritivo.

Embora 31 (48\%) dos artigos não especificassem a área correspondente dos estudos em questão, os estudos incluídos neste trabalho mostraram que a dramatização foi utilizada nos mais variados campos do saber, evidenciando a flexibilidade de aplicação dessa estratégia. 
Em sua totalidade, os 64 (100\%) estudos selecionados demonstraram resultados positivos com a utilização da dramatização, sendo que 49 (77\%) associaram a relação positiva na aquisição de conhecimento teórico e 42 (66\%) descreveram melhora na associação entre teoria e prática após a aplicação da estratégia. Esses achados refletiram a relação positiva da dramatização como estratégia facilitadora no processo educativo, além de contribuir para diversos aspectos importantes na formação do futuro profissional em Enfermagem, relacionados, em 14 (22\%) estudos, ao desenvolvimento de habilidades, reconhecimento e associação de informações de outros componentes curriculares, através da interdisciplinaridade. As habilidades comunicacionais foram favorecidas segundo $11(17 \%)$ estudos, e 5 (8\%) mostraram que a dramatização possibilitou o estímulo da criatividade dos estudantes e contribuiu na tomada de decisão. Descreveram que a dramatização aplicada em 19 (30\%) estudos favoreceu a melhoria do relacionamento interpessoal, comunicacional; em 29 (45\%), estimulou o pensamento crítico, contribuiu para a percepção e desenvolvimento do senso de coletividade e trabalho em grupo, além de 8 (13\%) estudos em que a estratégia propiciou um ambiente favorável para a aprendizagem e de $4(6 \%)$ que a associaram à melhoria do desempenho no estágio.

Dentre os 64 (100\%) estudos examinados, 8 (13\%) autores teceram comentários sobre dificuldades detectadas na aplicação da atividade dramatizada. Foi considerada dificuldade, em relação ao aluno, o embaraço diante dos colegas pelo medo de exposição no grupo, dificuldades em estabelecer prioridades, em discernir o que é relevante ou não na formação profissional, a ansiedade e a solicitação dos alunos, manifestando a necessidade de mais tempo para realizar a atividade e mencionando as dificuldades iniciais devido ao relacionamento entre os alunos.

Em outro estudo, verificou-se que a dramatização não contribuiu para melhorar a perspectiva profissional do grupo. Depreendeu-se que tal fato ocorreu devido ao interesse dos participantes em abordar outros temas, como relacionamento interpessoal e aspectos comunicacionais, mas o 
aspecto das expectativas profissionais não foi amplamente discutido pelo grupo. Um autor concluiu que não foi significativa a melhora do pensamento crítico. Acreditamos que tal dificuldade pode advir da carência dos conhecimentos necessários para que tais conteúdos se tornem significativos ou do fato do estudante não estar mobilizado para uma aprendizagem ativa.

Apenas um aluno expressou, em um estudo, o sentimento de incapacidade para cuidar do paciente. Entretanto, o autor não discorreu sobre as medidas tomadas para solucionar ou amenizar esse sentimento do estudante. Outra dificuldade encontrada estava associada à limitação da população envolvida no estudo, por ser uma amostra de conveniência e dificultar a generalização dos resultados.

Dentre as diferentes estratégias de ensino disponibilizadas na metodologia contemporânea, privilegia-se cada vez mais a construção do conhecimento, onde o aluno passa a ser o sujeito do processo educativo.

Sem exigir muitos recursos para a sua concretização, exceto um espaço, um tempo, um grupo de indivíduos, a dramatização apóia-se numa estrutura e define uma seqüência de ações, procedendo à transformação do espaço com a ajuda de cenários e objetos. Ao estabelecer um ponto de partida para a dramatização (texto, idéia, objeto, personagens, canção, dança, imagem), elabora-se um guia para a dramatização distinguindo, na estrutura seqüencial, as ações, as personagens, o local e o tempo. Ao organizar o material em função do projeto elaborado, o espaço é recriado permitindo uma forma de intervenção sonora a ser inserida na atividade e os cenários são construídos de acordo com o projeto definido. Ao final, cabe ao grupo analisar o trabalho realizado. Contudo, o que interessa é o processo de criação, a trajetória percorrida em direção ao objetivo almejado na construção do saber centrado no ser humano.

Sintetizando, no cenário educacional, a dramatização como estratégia responde a necessidades de dois grandes pólos: de um lado, o indivíduo; de outro lado, o processo de aprendizagem. Para o indivíduo, a expressão dramática ajuda-o a conhecer-se, a conhecer o meio que o rodeia e a 
conhecer os outros e, de forma ativa e participativa, favorece a aprendizagem como expectativa final do processo educativo.

Aceitar esses fatos e trocar as propostas didáticas distantes e abstratas por outras contextualizadas, inscritas em tempos e espaços determinados, é admitir a validade da inserção do saber cotidiano na construção e na produção do conhecimento.

Concluímos que os resultados dos estudos refletem a contribuição positiva da dramatização como estratégia facilitadora do processo educativo, pois é um recurso que favorece a aprendizagem, confere significados aos conteúdos, colabora no desenvolvimento de habilidades técnicas e comunicacionais, na percepção do ser humano de maneira holística, estimulando a criatividade, o pensamento crítico e o relacionamento interpessoal, além de proporcionar um ambiente tranqüilo e seguro para o processo de ensino e aprendizagem. Favorecendo a construção das competências, a dramatização contribui na formação do futuro profissional em Enfermagem.

O método da revisão sistemática apresentando os resultados de estudos científicos foi apropriado para a pesquisa sobre a utilização da dramatização no ensino em Enfermagem por contribuir para a divulgação do conhecimento que edificará uma prática educativa de qualidade, baseada em evidências, favorecendo, inclusive, estudos posteriores sobre o assunto. Em decorrência da heterogeneidade dos tipos de estudos pesquisados, não foi possível realizar a metanálise dos resultados encontrados. 


\section{APÊNDICE}




\section{APÊNDICE}

Etiqueta elaborada como protocolo para identificação dos estudos encontrados (formato eletrônico e impresso).

Título:

Autor:

Fonte:

País:

Tipo de estudo:

Nível da População: ( ) técnico ( ) graduação ( ) pós-graduação

Metodologia:

Resultados:

Área:

Categorias específicas de resultados e conclusões sobre o uso da dramatização:
a) Resultado da aplicação:
( ) positivo
( ) negativo
b) Conhecimento teórico:
( ) $\operatorname{sim}$
( ) não
c) Associação teórico-prática:
( ) $\operatorname{sim}$
( ) não
d) Habilidades:
e) Aplicação na prática (estágios):
( ) $\operatorname{sim}$
( ) não
f) Pensamento crítico:
( ) $\operatorname{sim}$
( ) não
g) Criatividade:
( ) $\operatorname{sim}$
( ) não
h) Tomada de decisão:
( ) $\operatorname{sim}$
( ) não
i) Aspectos comunicacionais:
( ) $\operatorname{sim}$
( ) não
j) Relacionamento interpessoal:
( ) $\operatorname{sim}$
( ) não
k) Ambiente de aprendizagem:
( ) $\operatorname{sim}$
( ) não
1) Dificuldades:
( ) $\operatorname{sim}$
( ) não

m) Outros: 


\section{REFERÊNCIAS}




\section{REFERÊNCIAS}

1. Tobase L, Takahashi RT. Qualificação profissional dos enfermeiros no ensino médio. Nursing (São Paulo). 2004; 68(7): 38-42.

2. Hoffman J. Avaliar para promover: as setas do caminho. Porto Alegre: Mediação; 2001.

3. Ferreira $A B H$. Dicionário Aurélio básico da língua portuguesa. Rio de Janeiro: Nova Fronteira; 1995.

4. Libaneo J C. Didática. São Paulo: Cortez; 1992.

5. Brasil. Lei n. 9394, de 20 de dezembro de 1996. Estabelece as diretrizes e bases da educação nacional. Diário Oficial da União, Brasília, 23 dez. 1996. Seção 1, p. 27833-41.

6. Rios TA. Ética e Competência. São Paulo: Cortez; 2004.

7. Obry O. O teatro na escola. São Paulo: Melhoramentos; [s.d.].

8. Brasil. Ministério da Saúde. Proposta pedagógica: o campo da ação. $2^{a}$ ed. Brasília; 2002. (Formação pedagógica em educação profissional na área de saúde: enfermagem, módulo 5).

9. Kawamoto EE. Aplicação do "aproveitamento de conhecimentos e experiências anteriores" nos Cursos Técnicos de Enfermagem: a situação das escolas do Município de São Paulo. [dissertação] São Paulo: Escola de Enfermagem, Universidade de São Paulo; 2005.

10. Perrenoud P. Construir as competências desde a escola. Porto Alegre: Artes Médicas Sul; 1999. 
11. Luckesi CC. Filosofia da educação. São Paulo: Cortez; 1994.

12. Freire P. Pedagogia do oprimido. São Paulo: Paz e Terra; 2000.

13. Freire P. Pedagogia da autonomia. São Paulo: Paz e Terra; 1997.

14. Tobase L, Takahashi RT. Ensino de enfermagem em nível médio: utilização de estratégia facilitadora com material reciclável. Rev Esc Enferm USP. 2004;38(2):175-80.

15. Luckesi CC. Avaliação da aprendizagem escolar. $15^{a}$ ed. São Paulo: Cortez; 2003.

16. Latz PA, Nordbye D. Educating nurses into the perioperative arena. AORN J. 2004;79(5):965-9.

17. Isaacson JJ, Stacy AS. Nursing students in an expanded charge nurse role: a real clinical management experience. Nurs Educ Perspect. 2004;25(6):292-6.

18. Bartfay WJ, Rombough R, Howse E, Leblanc R. Evaluation: the OSCE approach in nursing education. Can Nurse. 2004;100(3):18-23.

19. Lincoln $\mathrm{R}$, Layton J, Holdman $\mathrm{H}$. Using simulated patients to teach assessment. Nurs Outlook. 1978;26(5):316-20.

20. Saeki T, Correa AK, de Mello Souza MC, Zanetti ML. O psicodrama pedagógico: estratégia para a humanização das relações de trabalho. Rev Bras Enferm. 2002;55(1):89-91.

21. Ketcham K. Role playing. Am J Nurs. 1952;52(3):334-5.

22. Moll R, Cook LH, Saul J. Church programs as a first clinical experience. Nurse Educator. 2001; 26(3):122-4. 
23. Fallowfield L, Saul J, Gilligan B. Teaching senior nurses how to teach communication skills in oncology. Cancer Nurs. 2001;24(3):185-91.

24. Staib S. Teaching and measuring critical thinking. J Nurs Educ. 2003;42(11):498-508.

25. Baker K. Acting the part. Using drama to empower student. . Pract Midwife. 2000;3(1):20-1.

26. Brown ML. Role playing at an institute. Am J Nurs. 1953;53(9):1096-7.

27. Moreno LR. Trabalho em Grupo: Experiências Inovadoras na Área da Educação em Saúde. In: Batista NA, Batista SH. Docência em Saúde: temas e experiências. São Paulo: SENAC; 2004.

28. Ministério da Educação. Secretaria de Educação Fundamental. Parâmetros Curriculares Nacionais: Arte. Brasília; 1997.

29. Ortega y Gasset J. A idéia do teatro. São Paulo: Perspectiva; 1978.

30. Ferraz MHC, Fusari MF. Metodologia do ensino da arte. São Paulo: Cortez; 1999.

31. Courtney R. Jogo, teatro \& pensamento. São Paulo: Perspectiva; 1980.

32. Moreno JL. Introdução ao psicodrama. São Paulo: Mestre Jou; 1970.

33. Florez JER. O psicodrama pedagógico no Brasil. Antecedentes, realidades e experiências. [dissertação]. São Paulo: Escola de Comunicação e Artes, Universidade de São Paulo; 1986.

34. Romaña MA. Construção coletiva do conhecimento através do psicodrama. Campinas: Papirus; 1992. 
35. Vergara SC. Repensando a relação ensino-aprendizagem em Administração: argumentos teóricos, práticas e recursos. Rev Organizações Soc. 2003;10(28):131-42.

36. Kemeny B, Boettcher IF, DeShon RP, Stevens AB. Using experiential techniques for staff development: liking, learning, and doing. J Gerontol Nurs. 2006;32(8):9-14.

37. Kirschbaum DIR, Nozawa MR. O psicodrama em sala de aula: uma estratégia de ensino para o desenvolvimento do papel profissional da enfermeira. Rev Bras Enferm. 1993;46(3/4):314-6.

38. Martins JT, Opitz SP, Robazzi MLCC. O psicodrama como uma estratégia pedagógica no ensino de saúde do trabalhador. Rev Gaúcha Enferm.2004; 25(1):112-7.

39. Oliveira ZR. Educação da espontaneidade: uma perspective na formação de professores. [dissertação] São Paulo: Pontifícia Universidade Católica; 1978.

40. Lima T. Psicodrama em sala de aula. São Paulo: Vetor; 1998.

41. Puttini EF, organizadora. Psicodrama na educação. ljuí: Unujuí; 1991.

42. Aguiar MGG, Boery RNSO. Representações do aluno de graduação em enfermagem acerca da prática/papel do enfermeiro: um relato de experiência. Rev Bras Enferm.1994;47(1): 61-6.

43. Diniz N, Lopes RLM, Almeida MS, Gesteira SMA, Oliveira JF. Psicodrama como estratégia pedagógica: vivências no ensino de graduação na área de saúde da mulher. Rev Lat Am Enferm. 2000;8(4):88-94. 
44. Faleiros F, Sadala MA, Rocha EM. Relacionamento terapêutico com criança no período perioperatório: utilização do brinquedo e dramatização. Rev Esc Enferm da USP.2002;36 (1):58-65.

45. Chiesa AM. O uso de estratégias participativas para o conhecimento de representações sociais de mulheres na região de Pirituba / Perus com resultado classe III de Papanicolau. [dissertação] São Paulo: Faculdade de Saúde Pública, Universidade de São Paulo; 1993.

46. Lima GM. O psicodrama como investigação qualitativa em programas de promoção à saúde. [dissertação] Ribeirão Preto: Escola de Enfermagem de Ribeirão Preto, Universidade de São Paulo; 2001.

47. Goulart SF. Uma experiência de dramatização com alunos de enfermagem. [dissertação] Rio de Janeiro: Escola de Enfermagem Anna Nery, Universidade Federal do Rio de Janeiro; 1979.

48. Bondevik GT, Smith-Sivertsen T, Baerheim A. Use of actors to train medical students in communication skills.Tidsskr Nor Laegeforen. 2006;126(16):2118-21.

49. Lipp ME, Pereira MM, Justo AP, Matos TM. Cardiovascular reactivity in hypertensives: differential effect of expressing and inhibiting emotions during moments of interpersonal stress. Span J Psychol. 2006;9(2):15461.

50. Beard RL, Salas E, Prince C. Enhancing transfer of training: using roleplay to foster teamwork in the cockpit. Int J Aviat Psychol.1995;5(2):131-43.

51. Fulton Suri J. The Ergonomics Society--the Society Lectures 1999: the next 50 years: future challenges and opportunities for empathy in our science. Ergonomics. 2001;44(14):1278-89. 
52. Prince $\mathrm{RH}$. Teaching engineering ethics using role-playing in a culturally diverse student group. Sci Eng Ethics.2006;12(2): 321-6.

53. Ramos-Cerqueira ATA, Lima MCP, Torres AR, Reis JRT, Fonseca NMV. Era uma vez... contos de fadas e psicodrama auxiliando alunos na conclusão do curso médico. Interface Comun Saúde Educ. 2005;9(16):81-9.

54. Pinheiro AS, Moreira MIBG, Freitas MA. Ensino médico e promoção à saúde em creche comunitária. Rev Assoc Med Brás. 2001;47(4):32024.

55. Jacobsen T, Baerheim A, Lepp MR, Schei E. Analysis of role-play in medical communication training using a theatrical device the fourth wall. BMC Med Educ. 2006;14(6): 51.

56. Brown R, Doonan S, Shellenberger S. Using children as simulated patients in communication training for residents and medical students: a pilot program. Acad Med. 2005; 80(12):1114-20.

57. Duff $P$. Teaching and assessing professionalism in medicine. Obstet Gynecol. 2004;104(6):1362-6.

58. Kaufman A. Teatro pedagógico: bastidores da iniciação médica. São Paulo: Ágora; 1991.

59. Romaña MA. Psicodrama pedagógico: método educacional psicodramático. 2a ed. Campinas: Papirus; 1987.

60. Romaña MA. Do psicodrama pedagógico à pedagogia do drama. Campinas: Papirus; 1996. 
61. Romaña MA. Pedagogia do drama: 8 perguntas \& 3 relatos. São Paulo: Casa do Psicólogo; 2004.

62. Sellers SC. Testing theory through theatrics. J Nurs Educ. 2002;41(11):498-500.

63. Coelho P. O teatro na educação. Rio de Janeiro: Forense Universitária; 1978.

64. Piletti C. Didática geral. São Paulo: Ática; 2000.

65. Rocha EM. Comportamento comunicativo do docente de enfermagem e sua influência na aprendizagem do educando. [dissertação] São Paulo: Escola de Enfermagem, Universidade de São Paulo; 1999.

66. Wasylko Y, Stickley T. Theatre and Pedagogy: using drama in mental health nurse education. Nurse Educ Today. 2003;23(6):443-8.

67. University of York. Centre for Reviews and Dissemination (CRD) [homepage on the Internet]. [last updated 2007 abr. 13; cited 2005 ago. 06]. Available from: <http://www.york.ac.uk/inst/crd>.

68. Hulley SB, Cummings SR, Browner WS, Grady D, Hearst N, Newman TB. Delineando a pesquisa clínica: uma abordagem epidemiológica. $2^{a}$ ed. Porto Alegre: Artmed; 2003.

69. Galvão CM, Sawada NO, Trevisan M. Revisão sistemática: recurso que proporciona a incorporação das evidências na prática da enfermagem. Rev Lat Am Enferm. 2004;12(3):549-56.

70. Universidade Federal de São Paulo (UNIFESP). Centro Cochrane do Brasil. Curso de revisão sistemática e metanálise [homepage na 
Internet]. São Paulo; 2001 [citado 23 abr. 2005]. Disponível em: <http://www.virtual.epm.br/cursos/metanalise/>.

71. Nobre MRC, Bernardo WM, Jatene FB. A prática clínica baseada em evidências. Parte I - questões clínicas bem construídas. Rev Assoc Med Bras. 2003;49 (4):445-9.

72. Richardson WS. Ask, and ye shall retrieve. Evidence-Based Medicine. Evid Based Med. 1998;3(4)100-1.

73. Bernardo WM, Nobre MRC, Jatene FB. A prática clínica baseada em evidências. Parte II - buscando as evidências em fontes de informação. Rev Assoc Med Bras. 2004;50 (1):104-8.

74. Sackett Straus S, Richardson S, Rosenberg W, Haynes RB. Evidencebased medicine: how to practice and teach EBM. $2^{\text {nd }}$ ed. London: Churchill Livingstone; 2000. In: Nobre MRC, Bernardo WM, Jatene FB. A prática clínica baseada em evidências. Parte III - avaliação crítica das informações em pesquisas clínicas. Rev Assoc Med Brás. 2004;50 (2):221-28.

75. Levin RF. Strategies for teaching nursing research: role-play to simulate application of research findings. West J Nurs Res.1988;10(6):782-5.

76. Hernández F, Sancho JM, Carbonell J, Torti A, Simó N, SánchezCortez E. Aprendendo com as inovações nas escolas. Tradução de Ernani Rosa. Porto Alegre: Artmed; 2000.

77. Stacciarini JMR, Esperidião E. Repensando estratégias de ensino no processo de aprendizagem Rev Lat Am Enferm.1999;7(5):59-66. 
78. Demo P. Educar pela pesquisa. $2^{\mathrm{a}}$ ed. Campinas: Autores Associados; 1997.

79. Cyrino EG, Toralles-Pereira ML. Trabalhando com estratégias de ensino-aprendizado por descoberta na área da saúde: a problematização e a aprendizagem baseada em problemas. Cad Saúde Pública. 2004;20(3):780-8.

80. Evans K, Hind T. Getting the message across. Nurs Times. $1987 ; 83(18): 40-2$.

81. Berbel NAN. A problematização e a aprendizagem baseada em problemas: diferentes termos ou diferentes caminhos. Interface Comun Saúde Educ. 1998;1(2):139-54.

82. Isaacs LG de. El efecto de enseñar las destrezas del pensamiento crítico en un curso introductorio de enfermería. Rev Lat Am Enferm. 1994;2(2):115-27.

83. Lima MAC, Cassiani SHB. Pensamento crítico: um enfoque na educação em Enfermagem. Rev Lat Am Enferm.2000;8(1):23-30.

84. Martin C. The theory of critical thinking of nursing. Nurs Educ Perspect. 2002;23(5):243-7.

85. Williams LV. Patient role-play by learners. Nurs Times. 1978;74(34):1402-6.

86. Simões ALA, Favero N. O desafio da liderança para o enfermeiro. Rev Lat Am Enferm. 2003;11(5):567-73. 